
Quadrangle index (cont.)

Howard Pass quadrangle

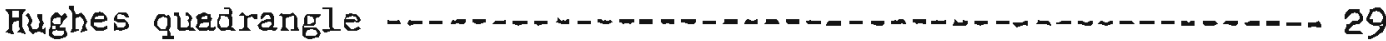

Icy Bay quadrangle wn...

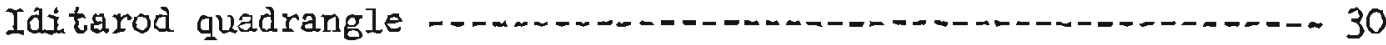

Ikplkpuk River quadrangle ...... 30

Iliamna quadrangle

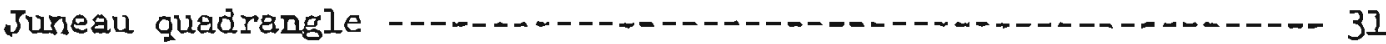

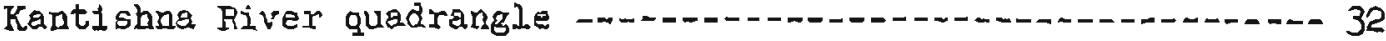

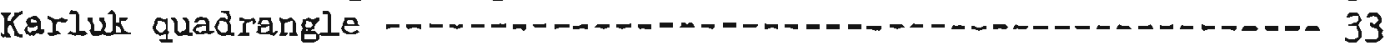

Kateel River quadrangle - .

Kenai quadrangle $\ldots \ldots \ldots$

Ketchikan quadrangle -n...

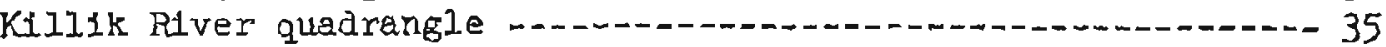

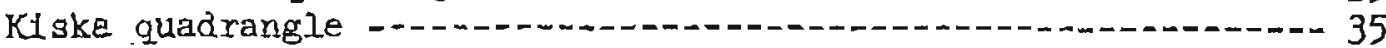

Kodlak quadrengle -

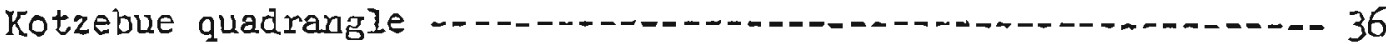

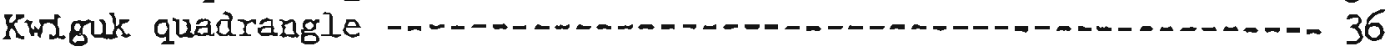

Lake clark quadrangle

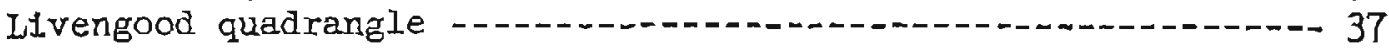

Loakout Ridge quadrangle

Marshall quadrangle .

McCarthy quadrangle -

Mcirath quadrangle -

Meade River quadrangle

Medfra quadrangle $\ldots \ldots$

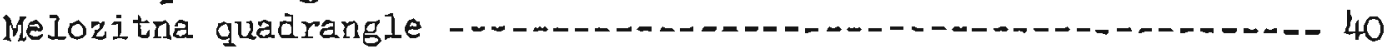

Middleton Island quadrangle $\ldots \ldots \ldots$

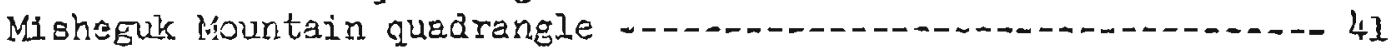

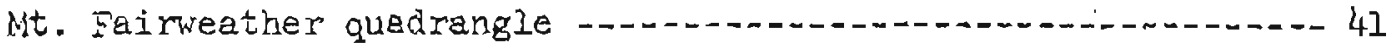

Mt. Hayes quadrangle

Mt. Katmai quadrangle $\ldots \ldots \ldots$

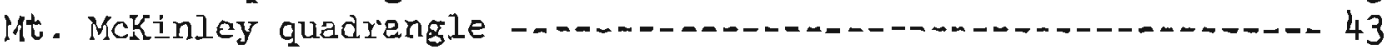

Mt. Michelson quad rangle ........... 44

Mt. St. Elias quadrangle $\ldots \ldots \ldots \ldots$

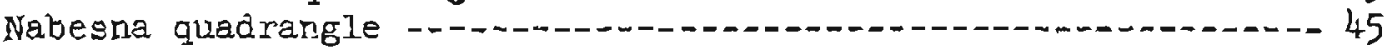

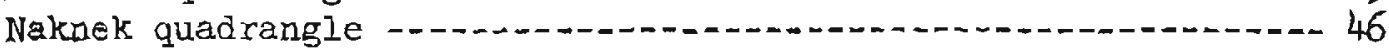

Noatak quadrangle $\ldots \ldots \ldots \ldots$

Nome quadrangle -...

Norton Bay quadrangle $\ldots \ldots \ldots$

Nulato quadrangle $\ldots \ldots \ldots$

Nunivak Island quadrangle -

Nushagak Bay quadrangle

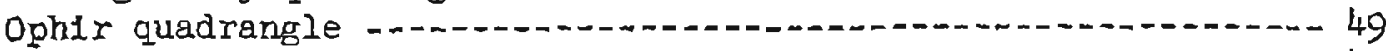

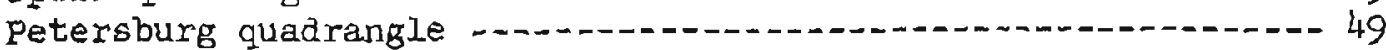

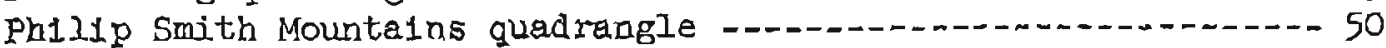

Point Hope quadrangle

Point Lay quadrangle

Port Alexander quadrangle $\ldots \ldots \ldots$

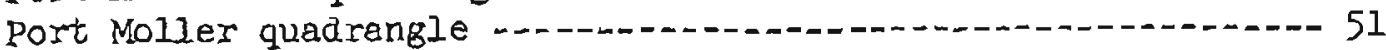

Prlbilof Islands quadrangle

Prince Rupert quadrangle $\ldots \ldots \ldots \ldots$

Rat IElands quadrangle 
Contents

Introduction

Alaska - General _........ 3

Quadrangle index -...... 7

Adak quadrangle ......

Afognak quadrangle -......... $T$

Ambler River quadrangle -....

Amukta quadrangle -

Anchorage quadrangle _........ 8

Atka quadrangle -..--... 10

Attu quadrangle -...... 10

Baird Inlet quadrangle -............ 10

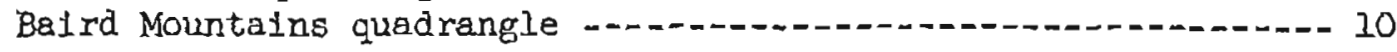

Barrow quadrangle . . . . .

Beaver quadrangle -

Bendeleben quadrengle -

Berting Glacier quadrangle -..... 13

Bethel quadrangle -

Bettles quadrangle -........ 14

Big Delta quadrangle -

Black quadrangle -...... 14

Bleck River quadrangle -......... 15

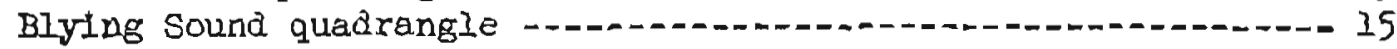

Bradfield Canal quadrangle ......... 15

Candle quadrangle -..... 16

Cape Mendenhall quadrangle _.... 16

Chandalar quadrangle

Chandler Lake quadrangle ......... 17

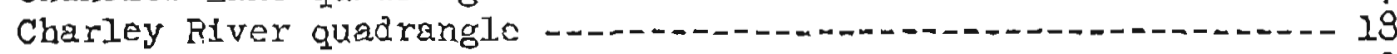

Chigntk quadrangle ........ 18

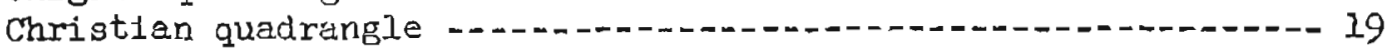

Circle quadrangle -...... 19

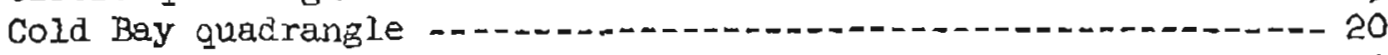

Coleen quadrangle -

Cordova quadrangle .

Craig quadrangle ..... 21

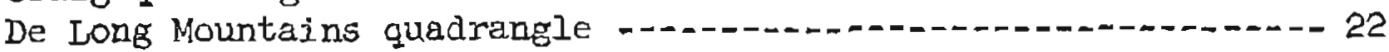

Dillingham quadrengle -......... 22

Dixon Entrance quadrangle ....... 22

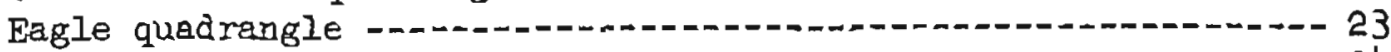

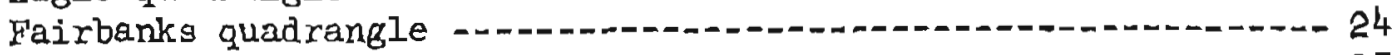

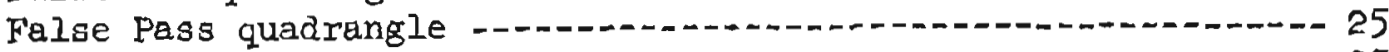

Fort Yukon quadrangle

Garelol Island quadrangle

Goodnews quadrangle . . 26

Gulkana quadrangle ....... 26

Hagemeister Island quadrangle - .

Farrison Bay quadrengle

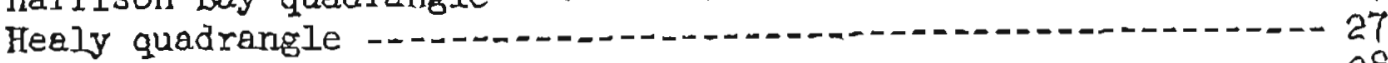

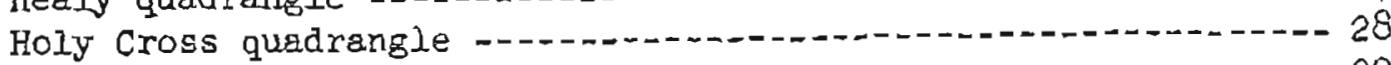

Hooper Bay quadrangle _... 29 
Quadrangle index (cont.)

Ruby quadrangle -n-

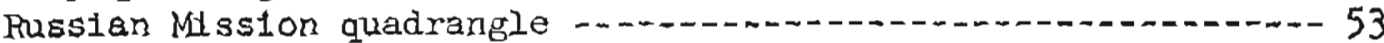

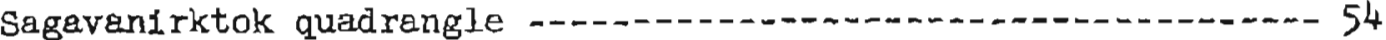

St. Lawreace quadrangle .

St. Mchael quadrangle - $\ldots+\ldots \ldots \ldots$

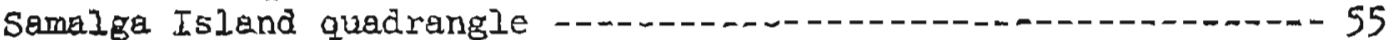

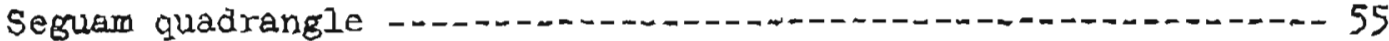

Selawlk quadrangle -.-.-

Seldovia quadrangle

Seward quadrangle -

Shy shmaref quedrangle

Shungnak quadrangle -........... 57

Sitke quadrangle

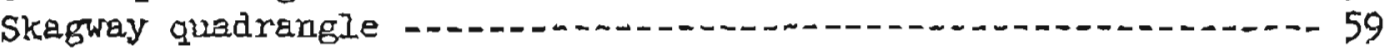

Sleetmute quadrangle . . $\ldots \ldots \ldots \ldots \ldots \ldots$

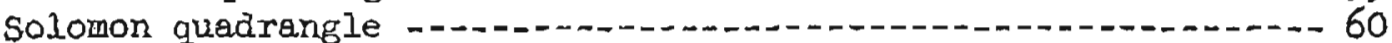

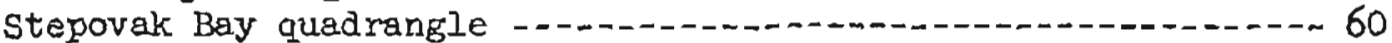

Sumdum quadrangle _......... 61.

Survey Pass quadrangle $\ldots \ldots \ldots \ldots \ldots$

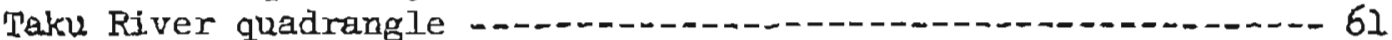

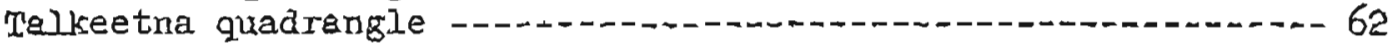

Talkeetna Mountalns quadrangle -

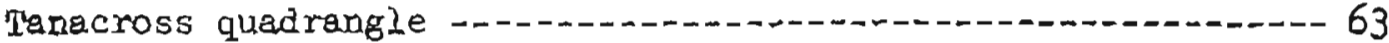

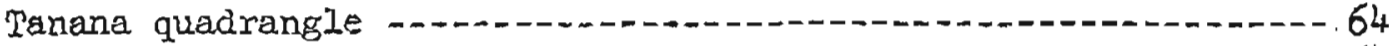

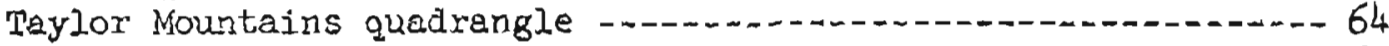

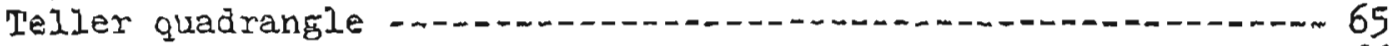

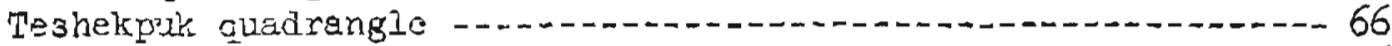

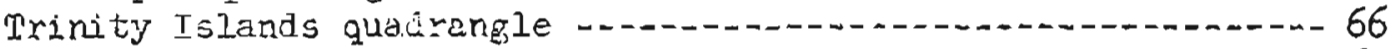

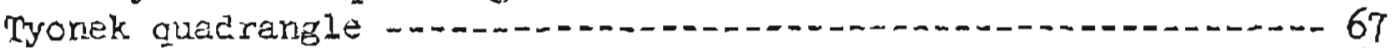

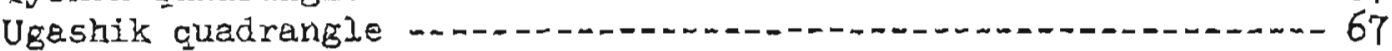

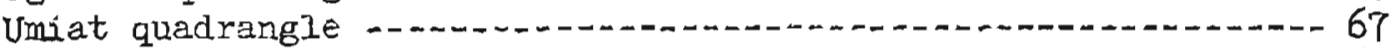

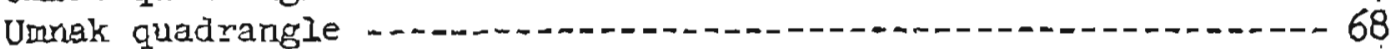

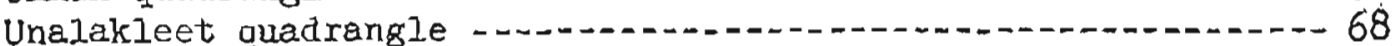

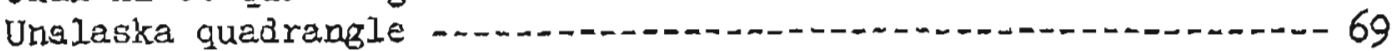

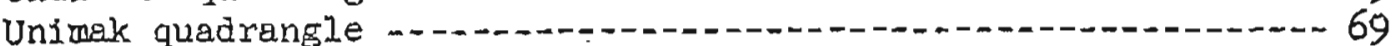

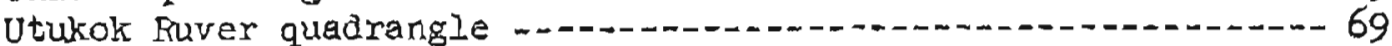

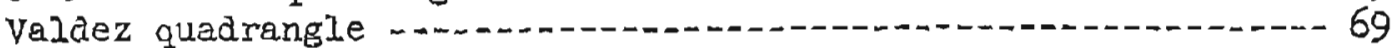

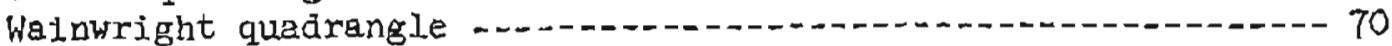

Wiseman quadrangle

Yakutat quadrangle $\ldots \ldots \ldots$ 


\section{Geological Survey published reporta on Alaska, 1940-1959, Indexed by quadrangle}

By Edward H. Cobb

\section{Introduction}

Geological Survey reports published a Professlonal Papers, Bulletins, Water Supply Papers, and Circulara are 11sted by the quadrangles (scale 1:250,000) 1nto which Alaska has been divlded for topograph1c mapping ( $p .2$ ). Th1s index does not lnclude reports that deal only with administrative matters or that were placed in open flles but not formally published.

Reports that deal with Alaska as a whole, whth areas that can not be 1dentified with any specific guadrangle, or with off shore areas that are not within quadrangle boundaries, or that consigt mainly of statigm tfcal data on the quality or quant1ty of water are l1sted under ALASKAGENERAL, as are blbllographles, indexes, and simflar publicattons. The AIASKA - GENERAL 1ist appears before the alphabet1cally arranged quadrangle llatings.

Th1s 1ndex is the stxth in a sertes of spectallzed lists, arranged by quadrangle, that will facllitate library research on the geology and mineral resources of Alaska. Prevlously released in the series are:

Cobb, E. H., 1974, Geolog1cal survey open-f1le reports on Alaska Indexed by quadrangle: U.S. Geol. Survey open-file report $74-7,116 \mathrm{p}$.

1974, Selected U.S. Bureau of Mines reports on Alagka 1ndexed by quadrangle: U.S. Geol. Survey open-f1le report 74-52, $40 \mathrm{p}$.

1974, Geological Survey maps (other than topographic) of Alaska lndexed by quadrangle! U.S. Geol. Survey open-flle report $74-84,38 \mathrm{p}$.

1974, Reports of the Alaska Division of Geological and Geophyolcal Surveys and predecessor sgencles, 1913-1973, 1ndexed by quadrangle: U.S. Geol. Survey open-f1le report 74-209, $112 \mathrm{p}$.

1974, Geological Survey pub11shed reports on Alaska, 19601973, Indexed by quadrangle: U.S. Geol. Survey open-f1le report $74-210,163 \mathrm{p}$. 


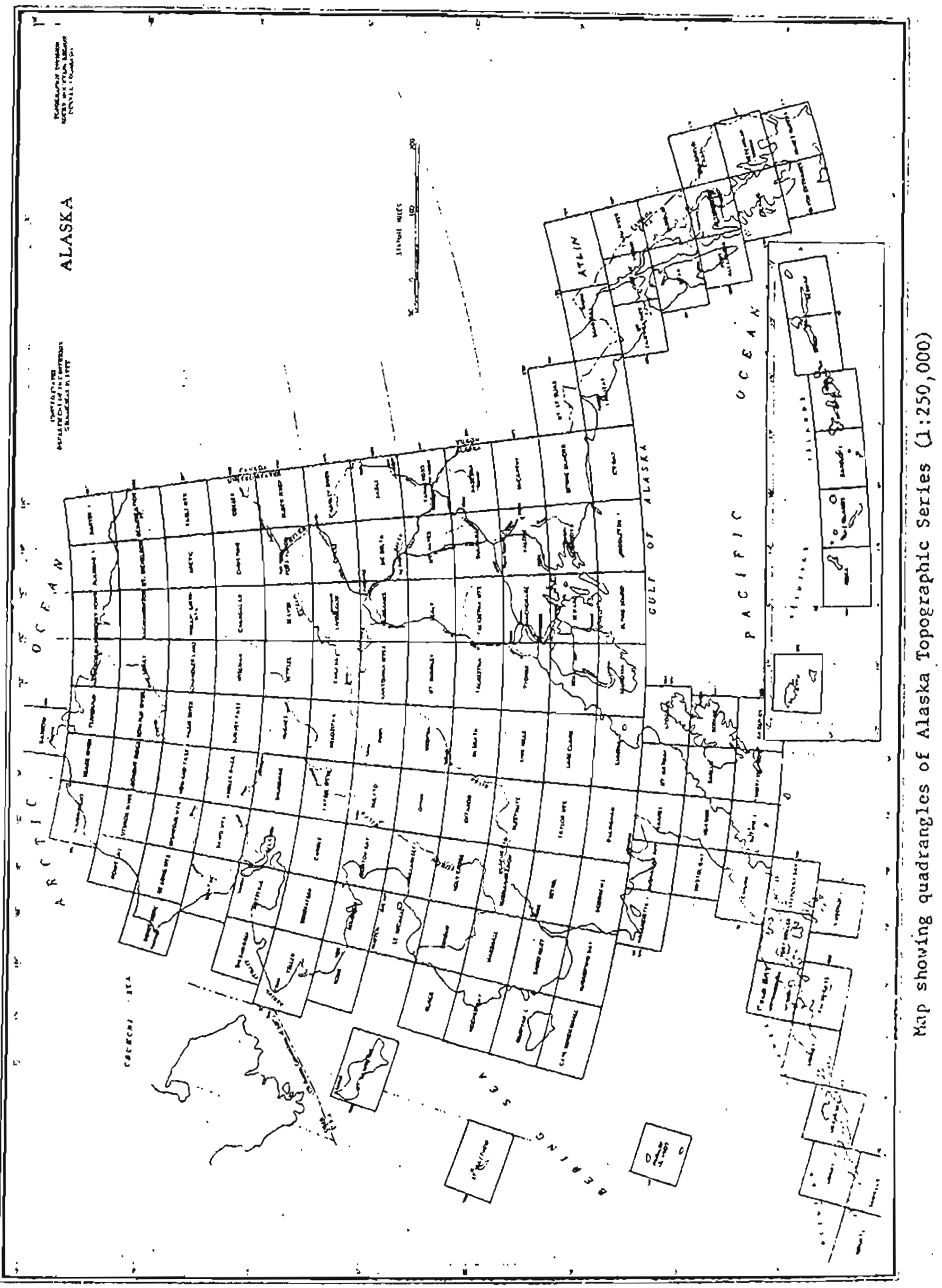




\section{$\Lambda I \Lambda S K A$ - GENERAL}

Smith, P. S., 19,4, Mineness of fold from Alaske placers! U.S. Geol. Survey Bull. 910-C, p. 147-272.

Smith, P. S., 1941, 2ast lode-gold production from Alaskat U.S. Geol. Survey Buli. 917-C, p. 159-212.

Smith, P. S., 1941, Mineral industry of Alaska in 1939: U.S. Geol. Survey BulI. 926-A, p. 1-106.

Smith, P. S., 19li2, Occurrences of molybderum minerals in Alaska! U.S. Geol. Survey Bull. 926-C, p. 161-210.

Sinth, P. S., 19t2, Mineral industry of Alaska in 1940: U.S. Geol. survey Bu11. 933-A, p. 1-102.

Sinth, P. S., 1944, Mineral industry of Alaske in 1941 and 1942: U.S. Geol. Survey Bull. 943-A, p. 1-23.

Waring, G. A., and Melnzer, O. E., 1947, Bibliograpby and index of publications relating to ground water prepared by the Geologlcal Survey and cooperating agencies: U.S. Geol. Survey Water-Supply Paper 992, 412 p.

Averttt, Paul, and Berryhil1, I. R., 1950, Coel resources of the United States, A progress report, November 1, 1950: U.S. Geol. Survey Circ, $94,33 \mathrm{p}$.

Costs, R. R., 1950, Volanic activity in the Aleutian arc: U.S. Geol. Survey Buli. 97t-5, p. 35-i9.

FitzGerald, Gorald, 1951, Surveying and mapping in Alaska! U.S. Geol. Survey Cire. 10.1, 24 p.

MeGuinress, C. L., 1951, The water situation in the United States, with special reserence to ground water: U.S. Geol. Survey Circ. 114,138 .

Tappan, Helen, 1951, Foraminifera from the Arctic slope of Alaska, General introduction and Part I, Triassle Foraminiferk: U.S. Ceol. Survey Prof. Paper 236-A, p. 1-20.

Cederstrom, D. I., 1952, surmary of ground-water development in Alaska, 1950: 11.3. Geol. Survey Circ. 169, 37 p.

Fepenshade, G. H., and Broedel, C. H., 1952, Annotated bibliography and index map of sulfur and pyrites deposits in the United siates and Alaske (including references to JuIy 1, 1951): U.S. Geol. Survey Cire. 257,48 p.

Luttrell, G.W., 2952, Bibllography of U.S. Geologlcal survey publications on copper (to January 1, 1952): U.S. Geol. Survey Circ. $178,17 \mathrm{p}$. 


\section{ALASKA - GENERAL}

Averitt, Paul, Berrohil1, I. R., and Taylor, D. A., 1953, Coal resources of the United States (a progress report, October 1, 2953): U.S. Geol. Survey Circ. 293, 49 p.

Bates, R. G., and hejot, lielmuth, Jr., 1953, preliminary summary review of thoriur-bearing minoral occurrences in Alaska: U.S. Geol. Survay Circ. 202, $13 \mathrm{p}$.

Cederstrom, D. J., Johrston, P. M., and Subitsky, Seymour, 1953, Occurrence end development of ground water in permafrost regions: U.S. Geol. Survey Circ. 275,49 p.

Imlay, R. W., 1953, Callovian (Jurassic) ammontes from the United States and Alaska, Part 2, Alaska Peninsula and Cook Inlet reglons: U.3. Geol. Survey Prof. Paper 249-B, P. 41-108.

Péwé, T. L., and others, 1953, Multiple glaciation in Alaska, a progress report: U.S. Geol. Survey Circ. 289, 13 p.

Twenhofel, W. S., 1953, Potential Alaskan mineral resourees for proposed electrochemical and electrometallurgical industries In the upper Lynn Canal area, Alaska! U.S. Geol. Survey Circ. 252, 14 p.

Wedow, Helmuth, Ir., ami othars, 1953, Preliminary summary of reconneissance for urarium and thorium in Alaske, 1952: U.S. Geol. Survey Cima, 2t:8, is $p$.

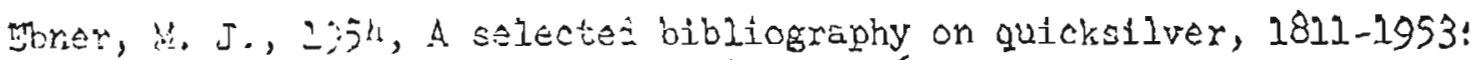
U.S. G=01. sumvej 5u11. $2319-A$, p. 1-62.

Pévé, T. L., 195:, Enfect of permefrost on cultivated fields, Fairbanks area, Alaska! U.S. Geol. Survey Bull. 989-F, p. 315-35l.

Wedow, Helmuth, Ir., Killeen, P. I., and others, 1954, Reconnaissance for radiosctive deposits in eastern interior Alaska, 1946: U.S. Geol. Suriey Cire. 331,36 p.

Cady, H. M., Wallace, R. E., Hoare, J. M., and Webber, E. J., 1955, The central Kuskokwirn reglon, Alaska: U.S. Geol. Survey Prof. Paper 268, $132 \mathrm{p}$.

Hopkins, D. M., Karlstrom, T. N. V., and others, 1955, Pemafrost and ground water in Alaska! U.S. Geol. Survey Prof. Paper 264-F, 1. $313-146$.

Teppan, Helen, 1955, Foraminifere from the Arctic slope of Alaska, Part 2, Jurassic Foraminifera: U.S. Geol. Survey Prof. Paper $236-\mathrm{B}, \mathrm{p} .21-90$. 


\section{AMASKA - GLNERAL}

Wallace, J. II., and Smith, H. B., 1955, Bibliography of U.S. Geological Survey trace elements and related reports to June 1, 1954: U.S. Geol. Survey Bul1. 1019-B, p. 63-144.

Bailey, E. G., 1956, Index of surface-water records to september 30, 1955; Alaska: U.S. Geol. Survey Circ. 396, 10 p.

Dutro, J. T., Jr., 1956, Annotated bibliography of Alaskan paleozole paleontology! U.S. Geol. Survey Bull. 1021-h, p. 253-287.

Buck, K. I., 1957, Selected annotated bibliograpby of thorium and rareearth deposits in the United States including Alaska: U.S. Geol. Survey Bull. 1019-F, p. 517-541.

Gazdik, G. C., and Tags, K. M., 1957, Annotated bibliography of highcalcium Iimestone deposits in the United States including Alaska, to April, 1958: U.S. Geol. Survey Bull. 1039-I, p. 675-713.

Lohr, E. W., 1957, chemical character of public water supplies of the larger cities in Alaska, Hawaii, and Puerto Rico, 1954! U.S. Geol. Survey Water-Supply Paper 1460-A, p. 1-39.

U.S. Geological Sumvey, 1957, Compilation of records of quantity and quality of surface waters of Alaska through Septenber 1950: U.S. Geol. Survey Water-Supply Paper 1372, $262 \mathrm{p}$.

iilson, Driid, Sando, i. J., and Kopt, R. W., 1957, Geologic names of North Armerica introduced in 1936-1955: U.S. Geol. Survey Bull. $1055-$ A, p. $1-405$.

Avery, R. B., Conant, M. L., and Weissenborn, H. T., 1958, Selected annotated bibliography of asbestos resources in the united states and Canada: U.S. Geol. Survey Buil. 1019-I, p. 817-865.

Jones, B. E., and Helland, R. O., 1958, Index to river surveys made by the United States Geological Survey and other agencies (revised to July I, 1947): U.S. Geol. Survey Hater-Supply Paper $995,145 \mathrm{p}$.

Pratt, E. M., and Cornwail, H. R., 1958, Bibliography of nickel: U.S. Geol. Survey Bull. 1019-K, p. 755-815.

Reed, J. C., 1958, Exploration of Neval Petroleum Reserve No. 4 and adjacent areas, northern Alaska, 1944-53, part 1 , History of the exploretion: U.S. Geol. Survey Prol. Paper 301 , 198 p.

Sigafoos, R. S., 1958, Vegetation of northwesterm North America, as an aid in interpretation of geologic data: U.S. Geol. Survey Bu??. 1061-r, p. 165-185. 


\section{ALASKA - GENGTAL}

Trumbu11, James, Liman, John, Pepper, J. F., and Thomesson, E. M.J 1958, An introduction to the geolosy and mineral resources of the cont1nental shelves of the Americas: U.S. Geol. Survey Bull.
$1067,92 \mathrm{p}$.

U.S. Geological Survey, 1958, Quantity end quality of surface waters of Alaska, October 1950 to September 1953: U.S. Geo1. Survey Water-Supply Paper 1.66, 243 p.

U.S. Geological Survey, 1958, Quantity and quallty of surface waters of Alaska, October 1953 to September 1956: U.S. Geol. Survey Water-Supply Paper 1486, 229 p.

Byers, F. M., Ir., 1959, Geology of Umrak and Bogosiof Islands, Alaske: U.S. Geol. Survey Bull. 1028-L, p. 267-369.

Fraser, G. D., and Sryder, G. I., 1959, Geology of southern Adak Island, Alaska: U.S. Geol. Survey Bull. 1028-M, p. 371-408.

Gottfried, David, Jaffe, H. W., and serftle, F. E., 1959, Evaluation of the lead-alpha age determinations of accessory minerals of igneous rocks: U.S. Geol. Survey Bull. 1097-A, Q. $1-63$.

Keller, A. S., and Reiser, H. N., 1959, Geology of the Mount Katmai area, Alaska: U.S. Geol. Survey Bull. 1058-G, p. 261-298.

iuttreli, G. W. , 2950, Amoteted bibliography on the geology of selerium: U.S. Geol. Survey Bull. 1019-Vi, p. 867-972.

Hiller, D. I., Frume, T. G., and Grye, Georee, 1959, Geology of possible cetroleum prouinces in Alaska, with an annotated bibllography by 2. H. Cobb: 1I.S. Geol. Survey Bull. 1094, 131 p.

Soister,"P: E., and corklin, D. R., 1959, Bibliography of U.s. Geological survey reports on uranium and thorium, 2942 through lay 1958 : U.S. Geol. Survey Bull. 1107-A, p. 1-167.

Wilcox, R. E., 1959, some effects of recent volcanic ash falls, with special reference to Alaska: U.S. Geol. Survey Bull. I028-N,
p. $409-476$.

wilson, Druid, Keroher, G. C., and Hansen, B. E., 1959, Index to the geologic names of North America: U.S. Geol. Surrey Bul1. 1055-B,
p. 407-622. 
Coats, R. R., 1950, Volcenic activity in the Aleutian arc! U.S. Geol. Survey Bull. 974-8, p. 35-49.

Simons, F. S., and Mathewson, D. E., 1955, Geology of Great Sitkin Island, Alaska: U.S. Geol. Survey Bull. 1028-B, p. 21-43.

Coats, R. R., 1956, Geology of nortberm Adak Island, Alaska: U.S. Geol. Survey Bull. $1028-c$, p. 45-67.

Coats, R. R., 1956, Geology of northern Kanaga Island! U.S. Geol. Survey Bull. 1028-D, p. 69-81.

Coats, R. R., 1956, Recommaissanee geology of some western Aleutian Islands, Alaska: U.S. Geol. Survey Bull. 1028-E, p. 83-100.

Fraser, G. D., and Barnett, F. F., 1959, Geology of the Delarof and westermmost Andreenof Islands, Aleutian Islands, Alaska: U.S. Geol. Survey Bull. 1028-I, p. 211-248.

Fraser, G. D., and Snyder, G. I., 1959, Geology of southern Adek Island, Alaska: U.S. Geol. Survey Bull. 1028-M, p. 371-408.

\section{AHOMHAK QUADRANGLE}

Coats, R. R., 1950, Volcaric activity in the Aleutian arc: U.S. Geol. Survey Bull. 9?:-3, Р. 35-49.

Keller, A. S., and Rezaer, $\because$. N., 1959, Geology of the Mount Katmai area, Alaska: U.3. Geol. Survey Bull. 1058-G, p. 261-298.

lililer, D.J., Payme, T. G., and Gryc, George, 1959, Geology of possible petroleum provinces in Alaska, with an annotated bibliography by E.H. Cobb! U.S. Geol. Survey Bul1. 1094, $131 \mathrm{p.}$

\section{AM,YSLTP RIVER QUADRANGIE}

Smith, P. S., 19hl, Fineness of fold from Alaska placers: U.S. Geol. Survey Bulz. 910-C, p. 147-272.

Smith, P. S., 1941, Mineral industry of Alaska in 1939: U.S. Geol. Survey Bull. 926-A, p. 1-106.

Smith, P. S., 1942, Mineral industry of Alaska in 1940: U.S. Geol. Survey Bull. 933-A, p. 1-102.

\section{AMTKTA QUADRANGLE}

Coats, R. R., 1950, Volcanic activity in the Aleutian arc! U.S. Geol. Survey BuIl. 974-3, p. 35-49. 


\section{ANCHORAGE QUADRANGIIF}

Capps, S. R., 1940, Geolory of the Aleska Railroad region: U.S. Geol. Survey Bull. $907,201 \mathrm{p}$.

Smich, P. S., 1941, Finenass of gold from Alaska plecers: U.S. Geol. Survey Bull. 910-C, D. 147-272.

Smith, P.S., 19l1, past lode-gold production from Alaska! U.S. Geol. Survey Tul1. $917-\mathrm{C}$, p. 159-212.

Smith, P. S., 1941, Mineral industry of Alaska in 1939: U.S. Geol. Survey Bull. 926-A, p. 1-106.

Smith, P. S., 1942, occurrences of molybdenum minerals in Alaska:

U.S. Geol. Survey Bull. 926-C, p. 161-210.

Smith, P. S., 1942, Mineral industry of Alaska in 1940: U.S. Geol. Survey Bull. 933-A, p. 1-102.

Sto11, W. C., 1944, Reletions of structure to mineral deposition at the Independence mine, Alaska: U.S. Geol. Survey Bull. 933-C, p. $201-217$.

Waring, G. A., 1947, Nonmetalliferous deposits in the Alaska Rallroad belt: U.S. Geol. Survey Circ. 18, $10 \mathrm{p}$.

Moffit, F. H., and Fellows, R. E., 1950, Copper deposits op the Prince Viliiam Sound district, Mlasks: U.S. Geol. Survey Bull. 963-B, p. $47-80$.

Barnes, F.F., 1951, Hining and exploration in 1945 in the Wishbone Hi13 coal distrlet, Matanuska Valley, Alaska, in Barnes, F. F., and others, Coal investigations in south-central Alaska, 194h-46: U.S. Geol. Survey Bull. 963-E, p. 193-201.

Sernes, F. F., and Ford, D. M., 1952, coel prospects ond coal exploration and deviopment in the lower Katanuska Valley, Alaska, in 1950: U.S. Geol. Survey Circ. 154, 5 p.

Cecierstrom, D. J., 1952, Sumary of ground-water development in Alaska, 1950: U.S. Geol. Survey Circ. $169,37 \mathrm{p}$.

Moxhem, R. M., and Nelson, A. E., 1952, Reconnaissance for rad1oactive deposits in south-central Alaska, 1947-49: U.S. Geol. Survey circ. $184,14 p$.

ihlte, M. G., West, W. S., Tolbert, G. J., Nelson, A. E.., and Houston, J. R., 1952, Preliminary summary of reconnalssance for uranium in Alaske, 1951: U.S. Geol. Survey Circ. 196, 17 p.

Eates, R. G., and Wedow, Helmuth, Jr., 1.953, Preliminery surmary review of thorium-bearine mineral occurrences in Alaska: U.S. Geol. Surrey Circ. $202,13 \mathrm{p}$. 
Eckhart, R. A., 1953, Gypsiferous deposits on Sheep Mountain, Alaska: U.S. Geol. Survey Bull. 989-C, p. 39-61.

Imlay, R. W., 1953, Callovian (Jurassic) entonites from the United States and Alaska, Tart 2, Alaska Peninsula and Cook Inlet reglons: U.S. Geol. Survey Prof. Paper 249-B, p. 41-108.

Péwé, T. L., and others, 1953, Multiple glaciation in Alaska, a progress report: U.S. Geol. Survey Clre. 289, 13 p.

Trainer, F. W., 1953, Preliminary report on the geology and groundwater resources of the Matanuska Valley agricultural area, Alaska: U.S. Geol, Survey Circ. 268, $43 \mathrm{p}$.

Thenhofel, W. S., 1953, potential Alaskan minerel resources for proposed electrochemical and elactrometallurgical industries in the upger Lynn Canal area, Alaska: U.S. Geol. Survey Circ. 252, $14 \mathrm{p}$.

Wedow, Helrauth, Jr., and others, 1953, preliminary summary of reconnaissance for uranium and thorium in Alaska, 1952: U.S. Geol. Survey Cire. $248,15 \mathrm{p}$.

Moffit, F. H., 1954, Geology of the Prince William sound region, Alaska: U.3. Geol. Survey Bull. 989-I, p. 225-310.

Rey, F. G., 195ir, Geolody and ore deposits of the hillow creek miniug district, Alaska! U.尺. Geol. Survey Bull. 1004, 86 p.

Barnes, F. F., and Payne, T. G., 1956, the Wishbone Hill district, l'átanusté roal fiela, Alaska: U.S. Geol. Survey Bull. 1016, $88 \mathrm{p}$.

Hoxhem, R. M., and Eckhart, 1956, Marl deposits in the Knik Arm area, Alaska: U.S. Geol. Survey Bull. 1039-A, p. 1-23.

Lohr, E. W., 1957, Chemical character of public water supplies of the larger clties in Alaska, Ilawaii, and Puerto Rico, 1954! U.S. Geol. Survey Water-Supply Paper 1460-A, p. 1-39.

Barnes, F. F., and Sokol, Daniel, 1959, Geology and coal resources of the Little Susitna district, Matanuska coal field, Alaska: U.S. Geol. Survey Bull. 1058 - D, p. 121-138.

Eckhart, R. A., and Plafker, George, 1959, Haydite raw material in the Kings River, Sutton, and Lawing areas, Alaska! U.S. Geol. Survey Buil. 1039-C, p. 33-65.

Miller, D. J., Payne, T. G., and Gryc, George, 1959, Geology of possible petroleum provinces in Alaska, with an anpotated bibliography by E. H. Cobb: U.S. Geol. Survey Bull. 1094, 131 p.

Milier, R. D., and Dobrovolny, Frnest, 1959, Surficial geology of Anchorage and vicinity, Alaska: U.S. Geol. Survey BuzI. 1093, $128 \mathrm{p}$. 
Coats, R. R., 1950, Volcanlc activity in the Alcutian arc: U.S. Geol. Survey Bull. 974-B, p. 35-49.

Simons, F. S., and Mathewson, D. F., 1955, Geology of Great Sitkin Island, Alaska! U.S. Geol. Survey Bull. 1028-B, p. 21-43.

Coats, R. R., 1956, Reconnaissance geology of some westem Aleutian Islends, Alaska! U.S. Geol, Survey Bull. 1028-E, p. 83-100.

\section{ATTU QUADRANGLE}

Coats, R. R., 1956, Recounaissance geoloey of some western Aleutian Islands, Alaska: U.S. Geol. Survey Bull. 1028-E, p. 83-100.

Davidson, D. F., and powers, H. A., 3959, SEleniulin content of some volcanic rocks from Western United states and Hawalian Islands: U.S. Geol. Survey Bull. 1084-C, p. 69-81.

\section{BAIRD INLES QUADRANGLE}

Nitiler, D. J., Payne, T. G., and Grye, George, 1959, Geology of possible petroleum provinces in Alaska, with an ennotated bibliography by E. II. Colib: U.S. Geol. Survey Bul1. 2094, 131 p.

\section{BAIM:S MOUNTAINS QUADRAYYLE}

Smith, P. S., 19h1, Fineness of gold from Alaska placers: U.S. Geol. Surrey BuIl. 910-C, p. 147-272.

Smith, P. S., 29h1, Mineral industry of Alaska in 1939: U.S. Geol. Survey Bull. 926-A, p. 1-106.

Smith, P. S., 1942, Mineral industim of Nlaska in 19\%0: U.S. Geol. Survey Bull. 933-A, p. 1-102. 
Cederstrom, D. J., Iohtiston, I. M., ani Subitsky, Seymour, 1953, Occurrence and develofment of ground water in permafrost regions: U.S. Geol. Survey cire. $275,49 \mathrm{p}$.

Imlay, R. W., 1955, Characteinistic Jurassic mollusks from northern Mlaska: U.S. Geol. Survey Prof. Paper 274-D, p. 69-96.

Tappan, Helen, 1955, Foraminifera from the Arctic slope of Alaska, Part 2, Jurassic Foraminifera: U.S. Geol. Survey Prof. Paper $236-B, p .21-90$.

MacNeil, F. S., 1957, Cenozoic megapossils of northern Alaska: U.S. Geol. Survey Prof. Paper 294-c, p. 99-126.

Todd, Ruth, 1957, Toraminifera from Carter Creek, northeastern Alaska: U.S. Geol. Survey Prof. Faner 294-F, p. 223-235.

Reed, J.C., 1958, Exoloration of Naval Petroleum Reserve No. 4 and adjacent areas, northern Alaska, 1944-53, part 1, History of the exploration: U.S. Geol. Survey prop. Paper 301, 192 p.

Iachenbruch, A. H., 1959, Perlodic heat flow in a stratified medium with application to permafrost problems! U.S. Geol. Survey Full. 1083-A, p. 1-36.

Lacherbuuch, A. H., anc Brewer, M. C., 1959; Dissipation of the temperature efiset of drilling a well In Arctic Alaska: U.S. Geol. Survey Buil. 1083-C, p. 73-109.

Yijler, D. T.; Payne, T. G., and Gryc, George, 1959, Geolocy of possible petroleus provinces in Alaska, with an annotated bibliography by

F. IT. Coos: U.S. Geol. Survey BuIl. loglt, 131 p.

soininson, i. H, 1959, Test wel1s, simpson erea, Mlaska, Hith a section on Core anelyses by $S$. T. Yuster: U.S. Geol. Survey Prof. Paper 305-T, p. 523-568.

spetzman, I. A., 1959, Vegetation of the Arctic Slope of Alaska: U.S. Geol. Survey prof. Paper 302-13, p. 19-58.

\section{REAVER QUADRANGLE}

Fricth, P. S., 19lik, filneness of gold from Alaska placers: U.S. Geol. Survey Buli. 910-C, p. 147-272.

smtth, p.5., 194s, occurrences of molybdenum mincrals in Alaska: U.S. Geol. Survey Bul1. $926-C, p .161-210$.

Hopkins, D. M., Karlstrom, T. N. V., and others, 1955, Pertatrost and ground water in Alaska! U.S. Geol. Survey Prof. Paper 264-F, p. $113-246$.

Atiler, D. J., Payne, T. C., ard Gryc, George, 1959, Geology of posstble petroleum provinces in Alaske, with an annotated bibilography by E. H. Cobb: U.S. Geol. Survey Bull. 2094,131 p. 


\section{B1.ADTRBEN QUADRANGIE}

Snith, P. S., 19!1, Fineness of gold from Alaska placers: U.S. Geol. surver Bull. 910-C, p. 147-272.

Smith, P. S., 1941, Past lode-cold production from Alaska! U.S. Geol. survey Bull. 917-c, p. 159-212.

Smith, P. S., 1941, Mineral industry of Alaska in 1939: U.S. Geol. Survey Bul1. 926- $\Lambda$, p. 1-106.

Smith, P. S., 19li2, Minerol industry of Alaska in 1940: U.S. Geol. Survey Bull. 933-A, p. 1 102.

Hopkins, D. M., and Sigafoos, R. S., 1951, Frost action and vegetation patterns on Sewara Peninsula, Alaska: U.S. Geol. Survey Bull. 974-C, p. $51-101$.

Bates, R. G., and Wedow, Helmuth, Jr., 1953, Preliminary summary review of thorium-bearine mineral occurrences in Alaska: U.S. Ceol. Survey Circ. 202, $13 \mathrm{p}$.

Gault, H. R., Killeen, P. L., West, W. S., and others, 1953, Reconnaissence for radioactive deposits in the northeastern part of the Beward Penjnsula, Alaska, 1945-47 and 1951: U.S. Geol. survey Circ. 250, $31 \mathrm{p}$.

Moxhan, T. M. and West, W. S., 1953, Radioactivity investigations in the Serpentine-Kougarok area, Seward Peninsula, Alaska, 1946:

U.S. Geol. Sulvey Cire. 265, 11 p.

pévé, I. L., and oblers, 1953, Multiple glaciation in Alaska, a progress report: U.S. Gsol. Survey Cire. 289, 13 .

Hest, H. S., 1953, Reconnalssance for radioactlve deposits in the Darby Mounteins, Scwaru Penłnsula, Aleska, 1948: U.S. Geol. Survey Circ. $300,7 \mathrm{o}$.

Hopkins, D. M., Karlstrom, T. N. V., and others, 1955, Permafrost and ground water in Alaska! U.S. Geol. Survey Prof. Paper 264-F, p. 113-146. 
Smith, P. S., 19il, Mineral industry of Alaska in 1939: U.S. Geol. Survey Bull. $926-A$, p. $1-106$.

Smith, P. S., 1942, Occurrences of molybderum minerais in Alaska: 1.S. Ceol. Survey Bull. 926-c, p. 16́1-210.

Smith, P. S., 19i2, Mineral industry of Alaska In 1940: U.S. Geol. Survey Bull. 933- $\Lambda, p, 1-10 \bar{c}$.

Barnes, F.F., 1951, A review of the geology and caal resources of the Bering River coal field, Alaska: U.S. Gool. Survey Circ. 146, $11 \mathrm{p}$.

Moxham, R. M., and Nelson, A. E., 195e, Reconnaissance for radio. active deposits in south-central dlaska, 19l.7-49: U.S. Geol. Survey Circ. 184,24 p.

Bates, R. G., and Wedow, Helmuth, Jr., 1953, Preliminary summary review of thorium-bearing mineral occurrences in Alaska: U.S. Geol. Survey Circ. 202, $13 \mathrm{p}$.

\section{BPTIET, OMBADMNCT}

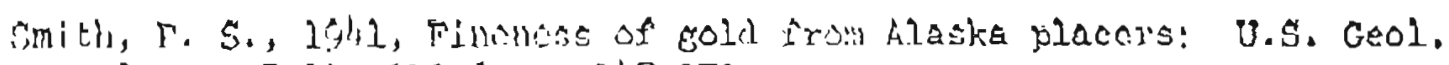
Aurey 3111 . 910-c, p. $147-272$.

Gith, P. S., 19i1, Miners1 industry oi klaska in 1939: U.S. Geol. iurvoy Fint. $926-A$, p. $1-206$.

Tmilh, P. S., 19li, Winera. industry of Aleska in 1940! U.S. Geol. Survey Bu.1.1. 933-A, P. 1.-102.

Cederstrom, D. J., 1952, Summary of ground-water development in Alaske, 1950: U.S. Ceol. Survey Cire. 169, 37 p.

Cady, W. M., Wallace, R. E., Hoare, J. M., and Webber, E. J., 1955, The central Kuskokwim reglon, Alaska: U.S. Geol. Survey Prof. Paper 268, $132 \mathrm{p}$.

Mijler, D. J., Payne, T. G., end Grye, George, 1959, Geology of possible petroleum provinces in Alaska, with an annotated tibliography by E. H. Cobb: U.S. Geol. Survay Bull. 1094, 131 p. 
BRTOTEFA QUADRANGER:

Cederstrom, D. J, 1952, Summary of ground-water development in Alaska, 1950: U.S. Geol. Survey Cire. 169, 37 p.

Welow, Helmuth, In, and otbers, 1953, Prelininary sumery of reconnaissance for urantum and thorium in Alaska, 1952: U.S. Geol. Survey C1rc. 2!18, 15 p.

Nelson, A. E., West, W. S., and Matzko, J. J., 1954, Reconnalssance for radioactive deposits in eastern Alaska, 1952: U.S. Geol. Survey Cire. 348 , 21 p.

BIG DETTA QUATRAINGPE

Capps, S. R., 1940, Geology of the Alaska Railroad region: U.S. Ceol.
Survey Bull. 907,201 p.

smith, P. S., 19il, Fineness of gold froin Alaska placers: U.S. Geol.
Survey Bull. $910-C$, p. $477-272$.

Smith, P. S., 1941, Mineral industry of Alaska in 1939: U.S. Geol. Survey Bull. 926-A, p. 1.-106.

Simith, P. S., 1942, Mineral industry of Aleska in 1940: U.S. Geol. Survey Bull. 933-A, p. 1-102.

Cajerstrom, D.J., 1952, Summary of ground-water development in Alaske, 1950: U.S. Geol. Survey Circ. 169, 37 p.

Fl:.é, T. Z., and others, 1953, Multiple glaciation in Alaska, a progress report: U.S. Geol. Survey Circ. 289, 13 p.

$\because \because i s i d, H e l n u t h$, Ir., Killeen, P. L., and others, 1954, Reconnaissance for radioactive deposits in eastarn intarior Alaska, 1946: U.S. Geal. Survey Circ. $331,36 \mathrm{p}$.

Motins, D. K., Karistrom, T. N. V., and others, 1955, Permafrost and ground water in Alaska: U.S. Geol. Survey Prof. Paper 264-F, p. $113-1146$.

Miller, D. J., Payne, T. G., and Gryc, George, 1959, Geology of possible petroleum provinces in Alaska, with an annotated bibliography by E. II. Cobb: U.S. Geol. Survey Bull. 1094, 131 p.

\section{BI ACK OUNDRANGLE}

lisler, D.J., Payre, T. G., and Grye, Georee. 1959, Geologs of possible petroleum provinces in Alaska, with an annotated bibliography by E. H. Cobb: U.S. Ceol. Survey Bull. 1094, 131 p. 


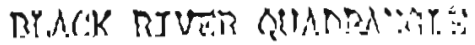

Fitzgerald, Gerald, $194 \mathrm{~h}$, Reconrej.ssonce oi Forcupine Valiey, Mlaska: U.S. Geol. Survey Bull. 933-D, p. 219-243.

Miller, D. J., Payne, T. G., and Gryc, George, 1959, Geology of possible petroleum provinces in Alaska, with en ennotated bibliography by E. H. Cobb: U.S. Geol. Sumey Eull. 1094, 131 p.

\section{BLYING SOUTD QUADSAIIGIE}

Capps, S. R., 1940, Geoloey of the Alaske mailroad region: U.S. Ceol. Survey Bull. 907,201 p.

Horfit, F. Il., and rellows, R. E., 1950, Copper deposits of the Prince Wlliam Sound district, Alasixa: U.S. Ceol. Survey Bull. 963-B, p. $47-80$.

Moffit, F. H., 195h, Geology of the Prirece W1lliam Sound region, Alaska: U.S. Geol. Survey Bull. 989-E, p. 225-310.

Stejer, F. A., 1956, Fyrite deposits at Horseshoe Bay, latouche Island, Alaska: U.S. Geol. Survey Bull. 102h-E, p. $207-122$.

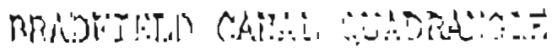

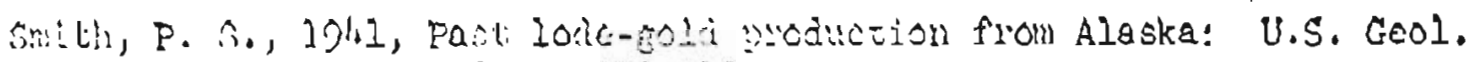
su:vey Full. 917-c, p. 159-232.

Smith, P. E., 19li, Mineral Encistm; oi jeska 14 1939: U.S. Geol. hurvey Mull. o26-A, F. $2-20^{\circ}$.

Smith, P. S., lghe, occurrenees of molybcenum minerals in Nlaska:

U.S. Geol. Survey Bull. 926-C, p. 1?i-210.

Smith, P. S., 1942, Mineral industry of Aliske in 1940! U.S. Geol. Survey Bull. 933-A, p. 1-102.

West, W. S., and Benson, F. D., 1955, Inrestigations for radioactive deposits in southeastern Alaska! U.3. Geol. Survey Bull. 1024-B, p. $25-57$.

Byers, F. M., Jr., and Seinsbury. C. L., 1956, Tungsten depostts of the Hyder district, Alaska: U.S. Geol. Survey Bul.1. 102h-F, p. 123-140. 


\section{CANDIE QUADIUNGSH:}

Mith, P. S., lyhl, Mineness of gold from Alaska placers: U.S. Geol. Survey Buil. 910-3, 19. $147-272$.

Smith, P. S., 19k1, Mineral industry of Alaska in 1939: U.S. Geol. Survey Bull. 926-A, p. 1-106.

Smlth, P. S., 19!t, Mineral industry of Alaska in 1940: U.5. Geoi. Survey Bu1]. 933-A, p. 1-102.

White, M. G., West, W. S., Tolbert, G. E., Nelson, A. E.; and Houston, J. R., 1952, Preliminary summary of reconnaissance for uranium in Alaska, 1951: U.S. Geol. Survey Circ. 196, 17 p.

Bates, R. G., and Hedow, Helmuth, Jr., 1953, Preltminary sumary review of thorium-bearing mineral occurrences in Alaska: U.S. Geol. Survey Cixc. 202, 13 p.

Gault, H. R., Killeen, P. L., West, W. S., ard others, 1953, Heconnaissance for radioactive deposits in the northeastern part of the Seward Prninsula, Alaska, 1945-47 and 1951: U.S. Geol. Survey Circ. 250, $3.1 \mathrm{p}$.

West, W. S., 1953, Reconneissance for radioactive deposits in tho narby Mountains, Seward Peninsula, Alaska, 1948: U.S. Geol. Survey Circ. $300,7 \mathrm{p}$.

liopkins, D. 1.., Karlstrom, T. N. V., and others, 1955, Permarrost arek ground ater ir tileska! U.S. Geol. Survey Prof. Paper 264-F, c. $12.3-1 \div 6$.

l.tiler, D. I., payne, T. G., and Grye, George, 1959, Geology of possible petroleum pivinces in Alaska, with an amotated bibliography by F. 11. Corb: U.S. CEOl. Survey Bull. 109h, $131 \mathrm{p}$.

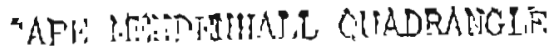

lililar, D. J., parme, T. G., and Gryc, George, 1959, Geology of possible petrolekr provinces in Alaska, with an annotated bibliography by E. H. Conh! I.S. Geol. Survey Bull. 1094, 131 p.

\section{CHATDAIAR GINDRANCTEF}

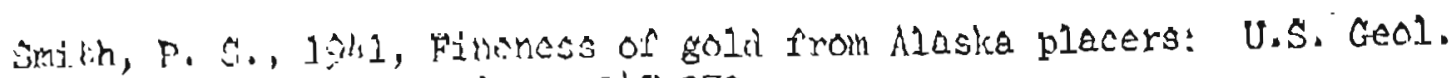
survey Buil. ilo-C, p. 147-272.

Smith, P. S., 19ii: past lode-pold production from Alaska: U.S. Geol. Survey Bull. in7-C, p. 159-212.

Smith, P. S., 191.2, Mineral jndustry of Alaske in 1939: U.S. Geol. Survey Bull. $926-\Lambda, p \cdot 1-106$. 
- -in, F. S., ighe, Mineral industry of Alaska in 1940: U.S. Geol. Surrey Bul1. 933-h, p. 1-102.

R:: concentratas from northeastern Alaske: U.S. Geol. Survey Circ. $195,12 \mathrm{p}$.

in:s, R. C., and iedow, Helmuth, Jr., 1953, Preliminary summary revier of thorium-bearing mineral occurrences in Alaska: U.S. Geol. Survey Circ. 202, $13 \mathrm{p}$.

$\because F i c ;$, Helmutr, $\mathrm{Tr}$, and others, 1953, Preliminary summary of reconnaissence for uranium and thorium in Alaska, 1952: U1.S. Geol. Sirvey cizc. 248, $15 \mathrm{p}$.

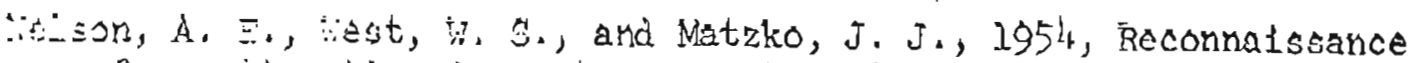
for rasiosctive dcposits in eastern Alaska, 2952! U.S. Geol. Surveg cire. 3lte, $21 \mathrm{p}$.

\section{CHATLER TAKT QUADRANGLF}

Dئ. 1. I. and others, 1953, Multiple glaciation in Alaska, a progress report: U.S. Geol. Survey Circ. $289,13 \mathrm{p}$.

iniey, R. B., 1055, characterdstic Jurassic mollusks from northern

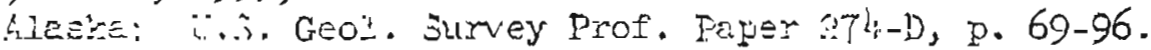

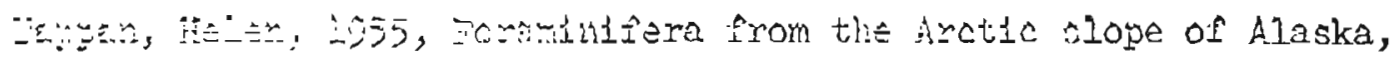

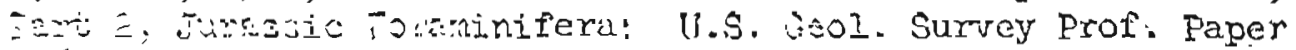

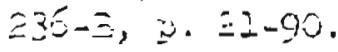

E...s. ... J., sna Dutro, J. T., Jr., 1957, The Paleozoto section ir tije Aneinin Lake area, central Brooks Range, Alaska: U.S. jeol. Suliy Prof. Faper 303-A, p. 1-39.

E:mor, Nackeside, Jr., 2957, Mississippien cephalopods of northem and eఏstim Alaska: U.S. Geol. Sur:ey prof. Paper 283, 61 p.

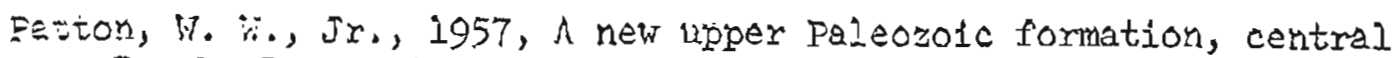
Brooks Renge, Alacka: U.S. Geol. Survey Proś. Paper 303-B, p. $41-45$.

Fiڤi, J. C., 1958, Exploration of Naval Fatroleum Reserve No. 4 and adjacent Eneas, northern Alaska, $19 i-4-5 \hat{j}$, part 1, History of the explomation: U.S. Geol. Survej Frof. Paper 301, 192 p.

Poizinson, $\bar{r}$. $\because ., 1958$, Test well, Grandstaild area, Alaska, with Micropaleontolozic study of Grandstand test well 1, northern Alaska, by H. ?. Bergquist: U.S. Geol. Survey Prof. Paper 305-E, p. 3IT339. 


\section{CHUNDLER LAKE QUADRALGLE}

Imlay, R. W., 1059, succession and speciation of the pelecypod Aucella: U.S. Geol. Survey Prof. Paper 314-G, D. 155-160.

Patton, W. W., Jr., and Matzko, J.J., 1959, Phosphate deposits in northem Nleska: U.S. Geol. Survey Prof. Paper 302-A, p. 1-17.

Spetzman, I. A., 1959, Vegetation of the Arctic Slope or Alaska! U.S. Geol. Survey prof. Paper 302-R, ร. 19-58.

\section{CHARLFY RIVER QUADRANGLF.}

Srith, q. S., 194.2, Fineness of gold from Alaska placers: U.S. Geol. Survey Bul1. 910-C, p. 147-272.

Smith, P. S., 1941, Mineral industry of Nlaske in 1939: U.S. Geol. Survey Bul]. 926-A, p. 1-106.

Hertie, J. B.,Jr., 1942, Tertiary deposits of the Eagle-Circle district, Alaska: U.S. Geol. Survey Bulz. 917-D, 0. 213-264.

Smith, P. S., 1942, Mineral industry of Alagka 1n 1940: U.8. Geol. Survey Bull. 933-A, p. 2-102.

Bates, R. G., and Wedow, Helmuth, Jr., 1953, Prellminary sumary review of thorium-bearing mineral occursences in Alaska: U.S. Geol. Surrey circ. 202, 13 p.

Yuwel, Bernhan, 1953, American Triastic colled nautlioids! U.S. Geol. Survey Proí. Paper 250, $104 \mathrm{p}$.

Vedow, Helmuth, $J r_{.}, 195 \%$, Reconnaissance for radioective depostts in the Eagle-Piation ares, east-central A.laska, 19!9: U.S. Geol. Survey Circ. $316,9 \mathrm{p}$.

Gorcion, Mackenzie, Jr., 1957, Mississipptan cephalopods of northern and eastern Mlaska: U.S. Geol. Survey Prof. Paper 283, 61 p.

Milier, D. J., Payne, T. G., and Gryc, George, 1959, Geology of possible petroleum provinces in Mlaska, with an annotated bibllography by E. K. Cobb: U.S. Gcol. Survey Bul1. $1094,131 \mathrm{p}$.

\section{CIIGIIY GUADRANGLE}

Coats, R. R., 1950, Volcenic activity in the Alentian arc: U.5. Geol. Survey Buld. 974-B, p. 35-49.

Miller, D. J., Payne, T. G., and Grye, George, 1959, Geolocy of possible petroleur provinces in Alaska, with an annotated bibliography by E. IT. Cobb: U.S. Geol. Survey Bull. 1094, 131 p. 


\section{CHRISTIAN GUADHANG?E}

lfiller, D. I., Peyne, T. G., and Gryc, George, 1959, Geology of possible petroleum provinces in Alaska, with an annotated bibliography by E. H. Cobb: U.S. Geol. Survey BuII. 1094, 131 p.

\section{CIRTLLT QUADRANGTI:}

Capps, S. R., 19lio, Geology of the Alaska Rallroad region: U.S. Geol. Survey Bull. 907, 201 p.

Smith, P. S., 1941, Fineness of gold from Alaska placers: U.S. Geol. Survey Bull. $910-C$, p. $147-272$.

Smlth, P. S., 1941, Past lode-gold production from Alake: U.S. Geol. Survey Bull. 917-C, p. 159-212.

Smith, P. S., 1941, Mineral industry of Alaska in 1939: U.S. Geol. survey Bull. 926-A, p. 1-106.

Simth, P. S., 1942, Mineral industry of Alaska in 1940: U.S. Geol. Survey Bull. 933-A, p. 1-102.

Cederstrom, D. J., 1952, Summary of ground-water development in Alaska, 1950: II.S. Geol. Survey Circ. 169, $37 \mathrm{p}$.

Hen, Helmuth, ir., and others, 1953, preliminary summary of reconraissance for uranium and thorium in Alaska, 1952: U.S. Geol. Survey Circ. $21,8,15 \mathrm{p}$.

Nisison, A. E., Vest, H. S., and Matzko, J. J., 1954, Reconneissance for radoactive deposits in eastern Alaska, 1952: U.S. Geol. Survey Circ. $3{ }^{1 / 8}, 2.2 \mathrm{p}$.

hedow, Helmuth, Jr., Killeen, P. L., and others, 1954, Reconnaissance for radiosictive deposits in eastern interior Alaske, 1946: U.S. Geol. Survey Circ. 331,36 p.

Wedow, Helmuth, Jr., White, M. G., and others, 1954, Reconnaissance for radioactive deposits in east-central Alaska, 1949: U.S. Geol. Survey Circ. 335, 22 p.

Cady, W. M., Wallace, R. E., Hoare, J. M., and Webler, E. J., 1955 , The central Kuskokwim region, Alaska: U.S. Geol. Survey Prof. Paper 268, $132 \mathrm{p}$.

Hopkins, D. M., Karlstrom, T. N. V., and others, 1955, Demafrost and ground water in Alaska: U.S. Geol. Survey Prố. Paper 264-F, p. $113-146$. 


\section{COTD BAY QUADRANGES}

Conts, R. R., 1950, Volcanle artivity in the Alcutian arc! U.S. Geol. Survey Bull. 97l-B, p. 35-49.

Kennedy, G. C., and waldron, H. H., 1955, Geolony of pavlof Volcano and vicinity, Alaska: U.S. Geol. Survey Bull. 1028-1, p. 1-19.

\section{COLEEN QUAORANGI,}

Fitzgerald, Gerald, 19!4, Recomnalssance of Porcupine Valley, Alaska: U.s. Geol. Survey Bull. 933-D, p. 219-243.

Wilte, M. G., 1952, Recomaissance for radioactive deposits alone the upper Porcupine and lower Coleen Rivers, northeastern Alaska! U.S. Geol. Survey Circ. 185, 13 p.

\section{CORDOVA QUADRANGLE}

Smitl, P.S., 194\}, Past lode-gold production from Mlaska! U.S. Geol. Survey bull. 917-C, p. 159-212.

Smith, R..S., 1942, Occurrences of molybdenum minerals in Alaska! U.S. Geol. Survey Bull. 926-C, p. 161-210.

Smith, P. S., 19li2, Mineral industry of Alaska in 1940: U.S. Geol. Survey Buld. 933-1, p. 1-102.

Barnes, F. F., 1951, A reviow of the geology and conl resources of the Bering River coal field, Alaska! U.S. Geol. Survey Circ. $146,11, \mathrm{p}$.

Yliler, D. J., 1951, Geology at the site of a proposed dam and reservolr on Power Creek near Cordora, Alaska: U.S. Geol. Survey Circ. $136,8 \mathrm{p}$.

Cederstrom, D. T., 1952, Summary of ground-water development in Alaska, 1950: U.E. Geol. Survey Circ. 169, 37 p.

Wedow, Heinuth, Jr., and others, 1953, Preliminary sumriary. of reconnalssance for uranium and thorium in Alaska, 1952! U.S. Geol. Survey Circ. $248,15 \mathrm{p}$.

Moffit, F. H., 195h, Geology of the Prince William Sound region, Alaska: U.S. Geol. Survey Bull. 989-E, p. 225-310.

M1ler, D. J., payne, T. G., and Gryc, Ceorge, 1959, Geology of possible petroleum provinces in Alaske, vith an annotated bibliography by E. H. Cobb: U.S. Geol. Survey Buld. 2094, 131 p. 
Smith, P. S., 1941, past iode-gold production from Alaska! U.S. Geol. Survey Bull. 917-C, p. 159-212.

Smith, P. S., 1941, Mineral Industry of Alaska in 1939: U.S. Ceo1. Survey Bu11. . 226-A, p. 1-106.

Smith, P. S., 19lie, decurrences of molybdenum minerais in Alaska: U.S. Geol. Survey Bull. 926-C, p. 161-210.

Smith, P. S., 1942, lineral industry of Alaska in 1940! U.S. Geol. Sumey Bull. 933-1, p. 1-102.

Konnedy, G.C., and Valton, M. S., Jr., 1946, Geology and associated mineral deposits of some Ultrabasic rock bodies in southeastern Alaska: U.S. Geol. Survey Bull. 947-D, p. 65-84.

Twenhofel, H. S., Robinson, G. D., and Gault, H. R., 1946, Molybdenite investigations in southeastern Alaska: U.S. Geol. Survey Bull. $947-B, 9.7-30$.

Waring, G. A., 1947, Nonmetalliferous ceposits in the Alasks Railroad velt: U.S. Geol. Furvey Circ. $18,10 \mathrm{p}$.

Twenhofel, V. S., Reed, J. C., and Gates, G. 0., 1949, Some mineral investigations in soutleastern Alaska: U.S. Geol. Survey Bull. $963-A, r . x-1,5$

Cenerstrom, D. J., 1952, Summary of ground-water development in Alaske, 1950: 11.j. Cool. Survey Cira. 169, $37 \mathrm{p}$.

Kirik, Bdwir, shel hitsien, T. W., 1952, Upper Silurian brachiopods from southsasterm. 1laska: U.S. Geol. Survey Prof. Paper 233-C, p. $53-66$.

Thite, H. G., Vest, t. S., Tolbert, G. T., Nelson, A. F., and Houston, J. R., 1952, Freliminary summary of reconnaissance for urantum in Alaska, 2951: U.S. Geol. Survey C1rc. 196, 17 p.

Kennedy, G. C., 1953, Geology and mineral depost ts of Jumbo basin, southeastern Alaska: U.S. Geol. Survey Prof. Paper 25I, 46 p.

Rotinson, G. D., and Th'enhofel, W. S., 1953, some lead-zinc and zinccopper deposjts of the Ketchikan and Wales districts, Alaska: U.S. Geol. Survey Rull. 998-C, p. 59-84.

Thenhofel, W. S., 1953, potential Alaskan mineral resources for proposed electrochemical and electronetallurgical industries in the upper Jymn Canal area, Alaska: U.S. Geol. Survey Circ. 252, $14 \mathrm{p}$.

Hedow, Helruth, Ir., and others, 1953, Prellminary sumary of reconnalssance for uranium and thorium in Alaska, 1952: U.S. Geol. Survey Circ. $248,15 \mathrm{p}$.

llouston, J.R., Bates, R. G., Velikanje, R. S., and Wedow, Helmuth, Jr., 1958, Reconnaissence for radioactive deposits in southeastern Alaska, 1952: U.S. Geol. Survey Bu.l1. 1053-A, p. 1-31. 


\section{CRAIC QUADRANGIS}

Larsen, F. S., Jr., Gottfried, David, Jarfe, H. W., and Wering, C. L., 1958, Leadi-alpha ages of the Nosozoic batholiths of western North Anerica: 1I.S. Geol. Survey Buld. 1070-B, p. 1-33.

Carr, M. S., and Dutton, C. F., 1959, Iron-ore resources of the United States includling Niaska and Puerto Rlco: U.S. Geol. Survey Bull. $1082-c, p, 51-134$.

Jaffe, K. W., Gottfrled, David, Warine, C. I., and Worthing, H. W., 1959, Lead-alpha age determinations of accessory minerals of igneous rocks (1953-1957): U.S. Geol. Survey Bull. 1097-B, p. 65-148.

Miller, D. J., Payne, T. G., and Gryc, George, 2959, Geology of possible petroleum provinces in Alaska, with an annotated bibliography by E. H. Cobb: U.S. Geol. Survey Bull. 109t, 131 p.

\section{DE. LONG MUNTAINS QUNNRANGLE}

Imlay, R. W., 1955, characteristic Jurassic moliusks from northern Alaska: U.S. Geol. Survey Prof. Paper 274-D, p. 69-96.

Imlay, R. H., 1959, Succession and speciation of the pelecypod Ancella: U.S. Geol. Survey Prof. Paper 3Il-G, p. 155-169.

\section{DPLLIIUTHUM OUUABRAMGLE}

Coderstrom, D. J., 1952, Summary of ground-water development in kiaska, 1.950: U.S. Geol. Survey Cire. 169, $37 \mathrm{p}$.

Pétié, i. L., and others, 1.953, Multiple glaciation in Alaska, a progress report: U.S. Geol. Survey Cilc. 289, $13 \mathrm{p}$.

Cajy, H. M., Wellace, R. F., Hoare, J. M., and Webber, F. J., 1955, The central Kuskokwim recion, Alaskn: U.S. Geol. Survey Prof.
Puper $268,132 \mathrm{p}$.

Hopkins, D. M., Karlstrom, T. N. V., and others, 1955, Permafrost and ground water in Mlaska: U.S. Ceol. Survey Prof. Paper 264-F,

Miller, D. I., Payme, T. G., and Grye, Coorge, 1959, Geology of possible petroleum provinces in Alaska, with an annotated bibliography by E. 11. Cobb: U.S. Geol. Survey Bull. 1094, . 31 p.

\section{DTXON RNTRANCE QUADTANGLE}

Smith, P. S., 19l1, Mineral industry of Alaska in 1939: U.S. Geol. Survey Bul1. 926-A, p. 1-106. 


\section{PAGIF: QUADRANGJAF}

Anith, P. S., 1.941, Frenest of Eold from Alacka placors: U.S. Geol. Survey Bull. 910-C, p. 147-272.

Smith, P. S., 19il, Mineral industry of Alaska in 1939: U.S. Geol. Survey Bull. 926-A, p. 1-106.

Mertie, J. B., Jr., 19le, Tertlary deposits of the Eagle-Circle district, Alaska: U.S. Geol. Survey Bull. 917-D, p. 213-264.

Srath, P. S., 19he, Occurrences of molybdenum minerals in Alaska:

II.S. Geol. Survey Bull. 926-C, p. I6I-210.

Smith, P. S., 1942, Mineral industry of Aleska in 1940: U.S. Geol. Survey Bull. 933-A, p. 1-102.

Wadow, Helruth, Ir, and others, 1953, Preliminary sumuary of reconnaissance for uranium and thorium in Alaska, 1952: U.S. Geol. survey Circ. $21 / 8,15 \mathrm{p}$.

Nolson, A. E., West, W. S., and Matzko, J. J., 1954, Reconnaissance for radioactive deposits in eastern Alaska, 1952: U.S. Geol. Survey Circ. 31103, $21 \mathrm{p}$.

Yedow, Helmuth, Ir., 195/, Reconnalssance for radioactive deposits in the Eagle-Nation arca, east-central Alaska, 1948: U.S. Geol. Survey cire. $316,9 \mathrm{p}$.

Holow, Melriuth, ir., Mite, M. G., ond others, 195h, Reconnaissance for radiosctive depo:ji.ts in cast-central Alaska, 19)19: U.S. Grist. Survey circ. $35 j$, 2e p.

Topkins, D. M., Karlstroin, T. N. V., and others, 1955, Permafrost and ground vater in NIaska: U.S. Geol. Survy Frof. Paper 264-F, p. $113-146$.

Gorion, Mackenzie, Jr., 1957, Mississippian cephalopods of northem and eastern Alazka: U.S. Geol. Survey Prof. Paper 283, $61 \mathrm{p}$. 


\section{MATRBAMS QUADRANGTE}

Capps, S. R., 39l:O, Geolocy of the Alaska Railroad region: U.S. ceol. Survey Bull. $907,201 \mathrm{p}$.

Smith, P. S., 1941, Fineness of gold from Alaska placers: U.S. Geol. Survey Bull. 910-6, p. 147-272.

Snith, P. S., 1941, past lode-gold production from Alaska! U.S. Geol. Survey Bull. 917-c, p. 159-212.

Smith, P. S., 19l1, Mineral induatry of Alaska in 1939: U.S. Geol. Survey Bull. 926-A, p. 1-106.

Smith, P. S., 19lic, Occurrences of molybdenum minerals in Alaska! U.S. Geol. Survey Bull. 926-C, p. 161-230.

Smith, P. S., 1942, Mineral industry of Alaska in 1940: U.S. Geol. Survey Bull. 933-A, p. 1-102.

Varing, G. A., 1947, Nonmetalliferous deposits in the Alaska Railroad belt: U.S. Geol. Survey Cire. 18, $10 \mathrm{p}$.

Péwe, T. L., 1949, Preliminary report of permafrost investigations in the Dunbar area, Alaska! U.S. Geol. Survey Circ. 42, 3 p.

Cederstrom, D. J., 1952, Summary of ground-water development in Alaska, 1950: U.S. Geol. Survey Circ. 169, 37 p.

White, M. G., West, W. S., Tolbert, G. L., Nelson, A. E., and Houston, J. R., 1952, Prelininary summary of reconnaissance for uranium in Alaska, 195l: U.S. Gasl. Sumoy Cire. 196, I' p.

Cederstrom, D. J., Johnston, P. M., and Subitsky, Seymour, 1953, Occurrence and development of Eround water in permafrost regions! U.S. Geol. Survey Cire. 275, it p.

Péwé, T. L., and others, 1953. Multiple glaciation in Alaska, a progress report: U.S. Geol. Survoy Circ, 289, $13 \mathrm{p}$.

Pévé, T. L., 1954, Effect of permafrost on cultivated fields, Fairbanks area, Alaska: U.S. Geol. Survey Bull. 989-F, p. 315-351.

Wedow, Helmuth, Jr., Killeen, P. L., and others, 1954, Reconraissance for radioactive deposits in eastern interior Aleska, 1946: U.S. Geol. Survey Circ. 331, $36 \mathrm{p}$.

Wedow, Helmuth, Jr., White, M. G., and others, 1954, Reconnaissance for radioactive deposits in east-central Alaske, I949: U.S. Geol. Survey Circ. 335, 22 p.

Hopkins, D. M., Karlstrom, T. N. V., and others, 1955, Permafrost and ground water in Alaska: U.S. Geol. Survey Prof. Paper 264-F, p. $213-146$.

Byers, M., Ir., 1957, Tunesten deposits in the fairbanks distriet, Alaska: U.S. Geol. Survey Bull. 1024-I, p. 179-216. 
FATABAMES QUADRANCY.ti:

Lohn, E. H., 195\%, Chemical character of public water supplies of the larber cities in Alaska, liavaii, and puerto Rico, 1954: U.S: Geol. Survey Water-Supply Paper $1160-A$, p. $.1-39$.

Wahrhafiz, Clyde, 1958, Quaternary geology of the Nenana ktver valley and adjacent parts of the Alaska Range: U.S. Geol. Survey Prof. Paper 293-A, p. 1-78.

Wahrhaft1 part of the Alaska Rallroad: U.S. Geol. Survey Prof. Paper 293-B, p. 79-118.

Millet, D. J., Payne, T. G., and Gryc, Geore, 1959, Geology of posstble petroleum provinces in Alaska, with an annotated bibliography by E. H. Cobb: U.S. Geol. Survey Bull. 1094, 132 p.

\section{FAISE PASSS QUUADRANGLE}

Coats, R. R., 1950, volcanic activity in the Aleutian are: U.S. Geol. Survey Bulu. 974-B, p. 35-49.

\section{FOKT: YUKON QUADRANCLE:}

Firacrald, Geralc, 19h4, Reconngissance of Porcupine valley, Alaska: U.S. Geol. Survey Bull. 933-D, p. 219-2li3.

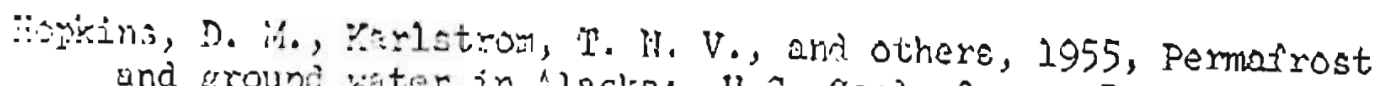
and ground water in hlaska: U.s. Geol. Survey Prof. Paper 26i-F,

Miller, D. J., Payne, T. G., and Gryc, George, 1959, Geoloby of possible petroleum provinces in Alaska, with an annotated bibliography by E. H. Cobo: U.S. Ceol. Survey Bu21. 1094, 132 p.

\section{GAPTTAI ISTAND QUNDRRUGLE}

Coats, R. R., 1950, Volcanic activity in the Aleutian arc! U.S. Geol. Survey Bull. 974-B, E. 35-49.

Coats, R. R., 1956, Reconnaissance geoloey of some western Aleutlon Islands, Nlaska: U.S. Geol. Survey Bull. 1028-E, P. 83-100.

Costs, R. R., 1959, Geologic reconnaissance of careloi Island, Aleutian Islands, Nleska: U.S. Geol. Survey Bull. 1028-J, p. 249-256.

Fraser, G. D., and Barnett, H. F., 1959, Geology of the Delarop and westernmost Andreanof Islands, Aleutian Islands, Alsaka: U.S. Geol. Survey Bul1. 1028-I, p. 211-248. 
Mertie, J. 8., Jr., 19/0, The Coolnews platinum renosits, Mlaska! U.S. Geol. Survey Bull. $918,97 \mathrm{p}$.

Smith, P. S., 19li, Fineness of Gold from Alaska placers: U.S. Geol. Survey Bull. 910-C, p. $147-272$.

Smith, P. S., 19hi, Mineral industry of Alaska in 1939: U.S. Geol. survey Bull. 926-A, p. 1-106.

Smith, P. S., 1942, Mineral industry of Alaska in 1940: U.S. Geol. , Survey Bul1. 933-A, p. 1-102.

Péwé, T. L., and others, 1953, Mutiple glaciation in Alaska, a progress report: U.S. Geol. Survey Cire. 289, $13 \mathrm{p}$.

\section{GULKANA QINDRANCLE}

Smith, P. S., 1941, Mineral industry of Alaska in 1939: U.S. Geol. Survey Bull. 326-A, p. 1-106.

Smith, P. S., 19ik, Mineral inaustry of Alaska in 1940: U.S. Geol. Survey Jull. 333-1, 1. 1-10e.

Morftt, r. II., 29/k3, Geology of the Mitzotin. Mountains, Alaska, with a section on the igneous rocks, by R. G. Waylend: U.S. Geol. Survey Bull. 933-B, p. 103-174.

lioffit, F. H., 1944, Mining in the northern Copper River region, Alaska: U.S. Geol. Survey Bul1. 943-B, p. 25-47.

Cederstrom, D. J., 1952, Summary of ground-water development in Alaska, 1950: U.S. Geol. Survey C1rc. 169, 37 p.

Wedow, llelmuth, Ir., and others, 1953, Preliminary sumary of reconnatssancc for uranium and thorium in Alaska, 1952: U.S. Geol. Survey Cire. $218,25 \mathrm{p}$.

Moffit, F. H., 1954, Geology of the eastern part of the Alaska Range and adjacent area: U.S. Geol. Survey Eull. 989-D, p. 63-218.

Nelson, A. E., west, W. S., and Matzko, J. J., 1954, Reconnaissance for radoactive deposits in eastem Alaska, 1952: U.S. Geol. Survey Circ. 348, 21 p.

Hedow, Helmuth, Ir., Killeen, T. L., and others, 1954, Reconneissance for radioactive deposits in castern interior Alaske, 1946: U.S. Geol. Survey Circ. $331,36 \mathrm{p}$.

Mller, D. J., Payme, T. G., and Gryc, George, 1959, Geology of posstble petroleum provinces in Alaska, with an annotated bibliography by E. H. Cobb: U.S. Geol. Survey Bull. 1094, 131 p. 


\section{MAGRATESTR ISTAND QUADRANGE}

Mertie, J. B., Tr., 1.40, The Goodnews platinum deposits, Alaske:

U.S. Geol. Survey Bull. 918, 97 p.

Smith, P. E., 19li, Mineral industry of Alaska in 1939: U.S. Geol. Survey Fol1. 926-A, p. 1-106.

smith, P. S., 1942, Mineral industry of Alaska in 1940: U.S. Geol. Survey Bul1. 933-A, p. 1-102.

\section{ILARISON BAY QUADRANGLE}

HacNeil, F. S., 1957, Cenozoic megafossils of northern Alaska: U.S. Geol. Survey Prof. Paper 294-c, p. 99-126.

Recd, J. C., 1058, Exploration of Naval Petroleum Reserve No. 4 and adjacent areas, northern Alaska, 1944-53, part 1, History of the explolation: U.S. Ceol. Survey Prof. Paper 301, $192 \mathrm{p}$.

Fobinson, F. M., anc Collins, F. R., 1959, Core test, sentinel Hill area and test well, Fish Creek area, Alaska: U.S. Geol. Survey
Prof. Paper $305-I$, p. $485-521$.

\section{ITH:YY GiUARAWGLE}

Carps, S. R., 10lk, Ceclopy of the Nlaska Railroad region: U.S. Ceol. Survey Euly. 30\%, zai E.

inth, n. S., 19li, strensse of gold from Nlaska placers! U.S. Ceol. Surrey bull. 910-C, p. 147-272.

Anith, P. S., lokl, Fest lode-rold production from Alaska! U.S. Geol. Survey Eull. 917-, p. 159-212.

Smith, P. S.. 1911, Mineral industry of Alaske in 1939: U.S. Ceol. Survey Bull. 926-, p. 1-106.

Sirtth, P. S., 29l.2, Mineral industry of Alaske in 1940: U.S. Geol. Survey Bull. 933-A, p. 1-102.

Waring, G. A., 1947, Nonmetalliferous deposits in the Alaska Railroad beit: U.S. Geol. Survey Circ. 18, $10 p$.

Hopking, D. M., 1951, lignite depostts near Broad Pass station, Alaska, in Barnes, F.F., and others, Coal investigations in south-central Alaska, 194k-1.6: U.S. Geol. Survey Bull. 963-F, p. 18\%-191.

Whrhaftig, clyde, 2951, ceology and coal deposits of the westein pert of the Nenana coal field, Alaska, in Barnes, F. F., and others, Coal investigations in south-central Alaska, 1944-16: U.S. Geol. Survey Bull. 963-F, p. 169-186. 


\section{HEALY QUADRANGTE}

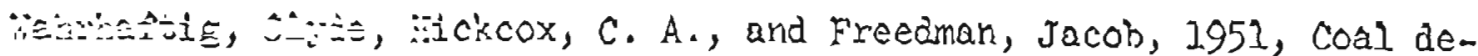

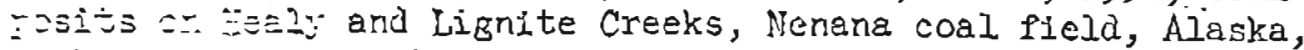
$\therefore i$ in $\Sigma$ $\equiv \equiv a j=n$ on clay deposits on Healy Creek, by $\mathrm{E}$. II. Cobb, in Sarnes, $\equiv$. F., and others, Coal investigations in south-central Ilaske, Jj-.i-i6: U.S. Geol. Survey Bull. 963-E, p. 141-168.

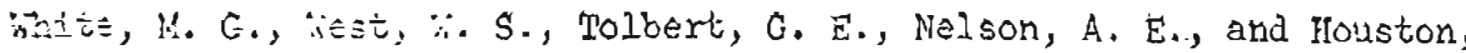

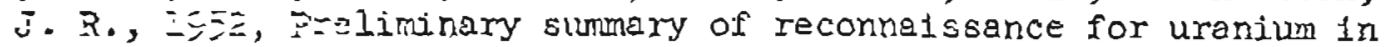
Eleske, $=9=$ : U.S. Geol. Survey Circ. 196, 17 p.

Péré, 1. I., Eud cthers, 1953, Multiple glaciation in Alaska, a progress report: i.3. Ceol. Survey Circ. $289,13 \mathrm{p}$.

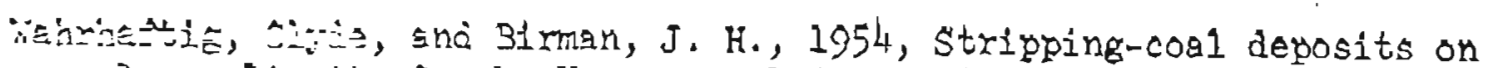
lorez : En: ireek, Nenana coal field, Alaska! U.S. Geol. Survey Airc.

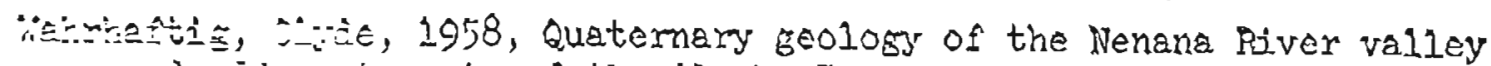
end $\equiv \equiv$ : $=n t$ parts of the Alaska Range: U.S. Geol. Survey Prof.

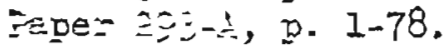

ith hrinestiz, Clyie, anc Black, R. F., 1958, Engineering geology along zart tz the 1isska Railroad: U.S. Geol. Survey Prof. Paper $293-3,2.79-113$.

Yaxisy, R. Y., Eckhert, R. A., and Cobb, E. R., 1959, Geology and cement

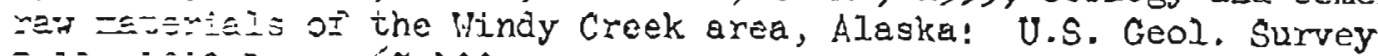
EuIi.

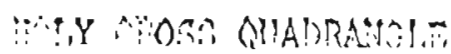

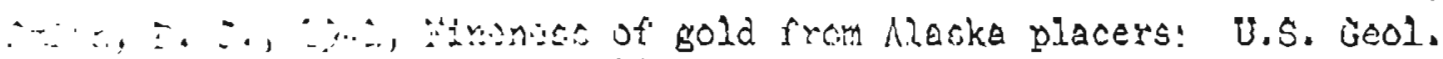

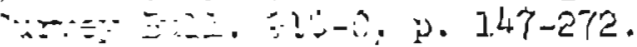

$\therefore \therefore, \approx \ldots, \because \therefore$, Yineral industry oi Alaska in 1939: U.S. Geol.

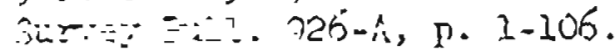

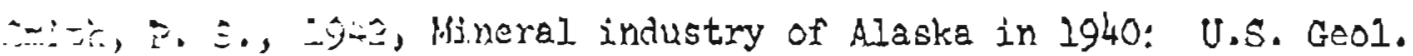
Sur.:

Ceisurstrez, S. J., 1952, Summary of ground-water development in Alasie, 1950: U.S. Geol. Survey Circ. 169, 37 p.

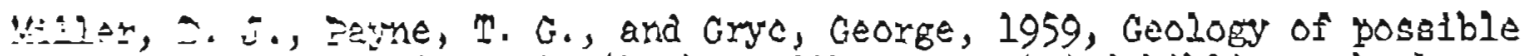
cetrois:m prcińnces in Alaska, with an annotated bibliography by

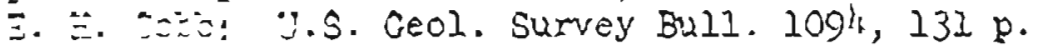


Milier, D. J., Payne, T. G., and Grye, George, 1959, Geology of possible petroleum provinces in Alaska, with an annoteted bibliography by E. H. Cobb: II.S. Geol. Survey Bull. 1094,131 p.

\section{IIOL!ARD PASS GUADRANGLE}

Imlay, R. W., 1355, Characteristic Jurassic nollusks from northern hlaska: U.S. Ceol. Survey Prof. Paper 274-D, p. 69-96.

Gordon, Mackenzie, Jr., 1957, Mississipplan cephalopods of northern and eastern Alaska: U.S. Geol. Survey Prof. Paper 283, 61 p.

Imlay, R. H., 2959, succession and speclation of the pelecypod Aucella: U.S. Geol. Survey Prof. Paper 314-G, p. 155-169.

Miller, D. J., Payme, T. G., and Gryc, George, 1959, ceology of possible petroleum provinces in Alaska, with an annotated bibliography by E. H. Cobb: U.S. Creol. Survey Bull. 1094, 132 p.

Patton, W. W., Jr., and Matzko, J. J., 1959, Phosphate deposits in northern Alaska: U.S. Geol. Survey Prof. Paper 302-A, p. 1-17.

\section{ItIGHES CQUDRANGLF}

anith, P. S., 19'1, Mineral industry of A.laska in 1939: U.S. Geol: surves bull. 920́-A, p. 1-105.

Coderstrom, D. J., 195ê, Summary of ground-water development in Alaska, 1950: U.S. Geol. Survey Circ. 169, $37 \mathrm{p}$.

Hiller, D. J., Payme, T. G., and Grye, George, 1959, Geology of possible petroleum provinces in Alaska, with an annotated biollography by E. H. Cobb: II.S. Geol. Survey Bull. 1094, 131 p.

\section{ICY BAY QIJAJRUNGLF:}

filike, D. J., Payne, T. G., and Gryc, George, 1959, Geology of possible petroleum provinces in Alaska, with an annotated blbliography by E. H. Cobb: 13.5. Gcol. Survey Bull, 1094, 131 p. 
Binjtil, P. S., lokl, finnyess or gold froin Alaska placejs! U.S. Geol. Survey Bull. 930-C, p. $147-272$.

Smith, P. S., 1941, past lode-goid production from Alaska! U.S. Geol. Survey sull. 917-C, p. 159-2l2.

Smith, P. S., 19h1, Minerel industry of Alaska in 1939: U.S. Geol. Survey Bul1. $926-A$, p. I-106.

Smith, P. S., 19lie, Mineral incustry of Alaslia in 1940: U.S. Geol. Survey Bull. 933-A, p. 1-10'e.

White, M. G., and Killcen, P. L., 1953, Reconnaissance for radioactive deposjts in the lower Yukon-Kuskokwim highlands region, Nlaska: [i.i. Geol. Surrey Circ. 255, $18 \mathrm{p}$.

Cady, W. M., Waljace, R. F., Ijoare, J. M., and Webber, I. J., 1955,

The central Kuskokwim refion, Alaska! U.S. Lrool. Survey Prof.

Eaper 266,132 p.

Jaffe, H. W., Gottfried, David, Waring, C. L., and Worthing, H. W., 1959, Lead-alpha age determinations of accessory minerale of 1gneous rocks (1953-1957): U.S. Geol. Survey Irull. 1097-B, p. 65-1!r.

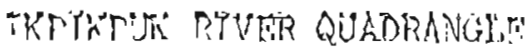

Touincon, r. H., 3055, Core tests and trat weljs, Oumalik area, Alasra, with Tu!n, nology of test wells and core tosts in the

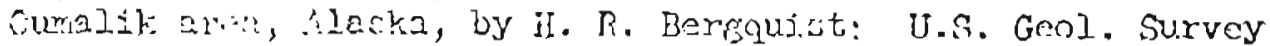
Trop. Faper $i: 5-\Lambda$, p. $1-70$.

Reca, T. C., 1958, TxpiLnation of Naval Petroleum leserve No. If and ajacent areis, northisn Alaska, $1944_{-53}$, part 1, Mistory of the exploration: U.A. Gool. Survey prot. Puper 301, 192 p.

Collins, F. R., 1959, Test vells, square Lake and wolf creek areas, Mlaska, with licropaleontology of Nquare Lake test well 1 and the Wolf Creck test wells, northem Alaska, by H. R. Bergquist: U.S. Geol. Survey Prof. Puper 305-H, p. 423-48\%.

Miller, D. J., payle, T. G., and Gryc, George, 1959, Geology of possible petroleum provinces in Alaska, with an annotated bibliograpliy by T.. H. Colbs: U.\$. Geol. Survey Bull. .209h, 131 p.

Robinion, F. M., 1959, Teet vells, Titaluk and Krifeblade areas, Mlaska, vith ilicropaloontologic study of test wells in the Thtaluk and Krireblarle areas, northern Alaska, by II. R. Bergquist: il. Geol. Survey Pror. Paper 305-G, p. 377-l.22. 
TIGANASA OUADEANGTE.

Aill P. S., 1041, Past lode-go.ld production from A.Laska! U.S. Geol. Sursey bull. 917-C, p. 259-212.

Fmith, P. S., 29L, Mineral industry of Nlaska in 1930: U.S. Geol. survey [in].1. 226-A, p. 1-10́́.

Sinth, P. S., 19ta, Ocsurrences of molybdenum minerals in Nlaska! U.S. Geol - Survey Bull. ge6-C, p. IGl-220.

Coats, R. R., 1950, Volcanic activity in the Alcutian are: U.S. Geol. Survey Bull. 97t-B, p. 35-1/9.

lioxham, R. ii., And IVelson, A. E., 195?, Reconnaissnnce for radioactive deposits in the southern Cook Inlet region, Alaska, 2949: U.S. Geol. Surver cire. $207,7 \mathrm{p}$.

Imlay, R. W., 1953, Callovian (Jurassic) amonites from the United States and Mlaska, Part 2, Mlaska Peninsula and Cook Inlet refions: U.s. Geol. Survey Prof. Paper 249-B, p. 4].-108.

Twe nhofel, W. S., 1953, Potential Alaskan mineral resources for proposed electrochemical and electrometallurgical industries in the upper lynn Canal area, Alaska: U.S. Geol. Survey circ. 252, 14 j.

r. What, P. A, Gri Plapkn, Georce, 1959, llavdite raw material in the Hing Riyer, wtion, and Iawing areas, Mlarka: U.s. Geol. Survey

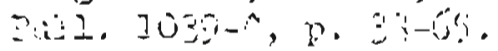

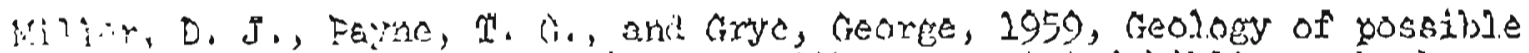

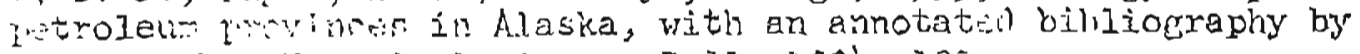
E. Il. Cohn: Ii.i. Geol. Survey Julz. I09\%, $131 \mathrm{p}$.

\section{TTINTAL QULARANGTHE:}

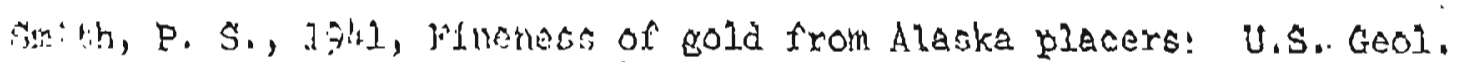
.urvey Bull. 910-c, p. 147-272.

Smith, P. S., 104l, past lode-gold production from Alaska! U.S. Geol. curvey Fal1. 917-C, p. 159-2.12.

Amith, P. S., 3, gh, Mincral industry of Alaska in 1939: U.S. Ceol.

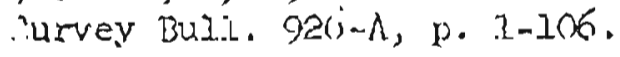

Procì, J. C., 13ir2, Nickil-conpor deposil at Bunter Bay, Admiralty Island, Aliska: U. G. Gcal. Survey Bull. 036-0, p. 349-361.

Smith, p. S., lghe, occurrences of molybdenum minerais in Alaska: U.S. Geol. Survey BuIl. 926-c, p. I6il-210. 


\section{JUNEAU QUADRANGLE}

Simith, P. S., 19li2, Mineral industry of Alaska in 2940: U.S. Geol. Survey Bull. 933-A, 0. 1-102.

Smith, P.S., 19h., Mineral indusiry of Alaska In 1941 and 1942: U.S. Geol. Survey Buld. $943-\Lambda$, p. $1-23$.

Twenhofel, W. S., Robinson, G. D., and Gault, 1T. R., 1916, Molybdenite investigations in southeastern Mlaska! U.S. Geol. Survey Bull. $347-\mathrm{B}, \mathrm{p} .7-38$.

Twonhofel, W. S., Reed, J. C., and Gates, G. 0., 1949, some mineral investigations in southcastorn Nlaska: U.S. Gcol. Survey Bujl. xis-A, p. $1-45$.

Cederstrom, D. J., 1052, Summary of cround-water development in M.laska, 1950: [Y.s. Genl. Survey Cire. 169, 37 p.

Johnson, Arthur, and Twenbofel, W. S., 1953, Fotentfal industrial sites in the I,ynn Canal area, Alaska: U.S. Geol. Survey Circ. $280,17 \mathrm{p}$.

Twenhofel, W. S., 1953 , potential Alaskan mineral resources for jroposed electrochemical and electrometallureical industries is the upger Tymn Canal area, Aleska: U.S. Geol. Survey i.i.re. 252, it: p.

kesil, W. S., and Benson, P. D., 3955, Investigations for radioactive $\therefore$ posits in southeastern Alaska! U.S. Geol. Survey Bull. 1024-B, I. 25-57.

Tokr, E. W., 1957, cherical character of public water supplies of the Jarear cities in Alaska, Ilwail, and Puerto Rico, 1.954! U.S. Geol. Survey Water-Supply Paper 1460-A, p. 3-39.

Tarom, E. S., Jr., Gottried, David, Jaffe, It. W., and Waring, C. L. 1358, Lear-alpha ages of the Mesozoic batholiths of vestern North America: U.S. Geol. Survey Bull. 1070-B, p. 1-33.

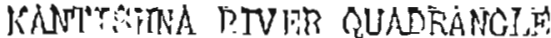

raple, S. R., 1040, Ganlory of the Alaske Railroed region: U.S. Ceol. Survey Buli. 907, ¿ul p.

Anderstrom, D. T., 105e, summary of eround-wat? development in

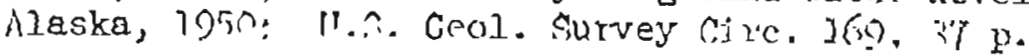

Mnxham, R. M., 195l, Reconnaissance ror radioactive deposits in the Manley Hot Springs-Rampart district, east-central Alaska, 1948: U.S. Geol. Survey Circ. 317, 6 p.

Miller, D. J., Payne, TH. G., and Gryc, George, 1959, Geology of possible petroleum provinces in Alaska, with an annotated biuliography by F. II. Colbb: 11.S. Geol. Survey Bull. 1094, $1.31 \mathrm{p}$. 
Sititi, F. S., 1.11, Minnel industry of Alaska in 1939: U.S. Geol. Survey Bu?.. 926-A, p. 1-106.

Simith, P. S., 1942, Mineral industry of Alaska in 10404 U.S. Geol. Survey Bulh. 933-A, p. 1-102.

Imlay, R. $w_{*}, 1,5,3$, Collovian (Jurassic) amonites from the United Statee ani Alaska, part 2, Alaska Peninsula and Cook Inlet reglons: U.i. Geol. Survey Prof. Paper 2!19-B, p. 4l-108.

Kummel, Bernherd, 1953, American Triassic coiled nautilolds: U.s. Geol. Survey Prof. Paper 250, $10 \% \mathrm{k}$.

Imlay, R. W., 1959, Succession and speciation of the pelecypod Aucelia: U.S. Gool. Survey Prof. Paper 3llk-G, p. 155-169.

Keller, A. S., and Reisor, H. N., 1959, Geology of the Mourt Katmel area, Alaska: U.S. Geol. Survey Bull. 1058-G, p. 261-298.

litiler, D. J., Payme, T. G., and Gryc, George, 1959, Geoloey of posstble petroleum provinces in Mlaska, with an annotated bihliography by E. II. Cobb: U.S. Ceol. Survey Bull. 2094,131 p.

\section{KASMFEL RIVER QUNARANGTF}

li: IlGr, D. Is, rayne, T. G., and Gryc, George, 1959, Geology of posstble petroleur province? Alaska, with an annotated bliliography by F. H. Colb: L.A. Sirol. Survey Tull, 1094, 131 b.

\section{KETAT GUADRANATIHF}

Carns, S. R., lol:D, Gcology of the Alaska Railroad region: U.S. Geol. Survey Buil. 907, ?101 p.

Sinitu, P. S., 1041, Hineness of gold from Alaske placers: U.S. Geol. Gurvey Bul1. 910-C, p. 147-272.

Coits, R. R., 1950, Volcanic activity in the Aleuttan arc: U.S. Geol. Survey Bull. 97h-8, p. 35-49.

Cederstrom, D. J., 1952, Summary of ground-water development in Aleska, 1950: U.S. Geol. Survey Cire. 169, 37 p.

Imlay, R. W., 1953, Callovian (Jurassic) ammonites fron the United States and Nitska, pert 2, Alaska Feninsula ans cook Inlet regions: IJ.S. Ceol. Survey Prol'. Paper 249-13, p. H.1-108.

Pévé, 1. L., and others, 1953, Multiple glaciation in Nlagka, a progress report: U.S. Geol. Survey Cire. $289,13 \mathrm{p}$. 


\section{KENAI QUADRANGLE}

Yovins, D. M., Karistrom, M. N. V., and others, 1955, Permstrost and ground witer in NJaska: U.S. Geol. Survey Prot. Fapor 26h-T, D. $113-1.46$.

Grantz, Arthur, Io56, Magnetite deporits at luxeanj Bay, Mlaska! U.s. Geol. Survey Bull. J(12l,-1), p. $95-106$.

Finfrer, George, 1956 , Occurrence of diatomaceous carth near Kenni, Aleske: U.S. Geol. Survey Bull. 2039-B, p. 25-31.

Gorion, Mackenzie, Jr., 1957, Mississippian cephalopods of northem and eastem Alaska: U.S. Geol. Survey Pror. Paper 283, 61 p.

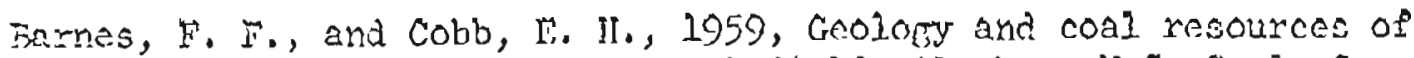
the Homor district, Kenai coal fleld, Alaska: U.S. Geol. Survey Bu11. 1058-r, p. 217-260.

IS11er, D. T., Payne, T. G., and Grye, George, 1959, Geolony of possible petrolewn provinces in Alaska, with an annotated bibliography by

E. H. Cobb: U.S. Geol. Survey Bull. 10n/, 131 p.

\section{KETCITKAN QQUALRANGTE}

Amith, P. S., Johl, past lode-cold production from Mlaska! U.S. Geol. A:-yey iu11. it7-c, p. 159-212.

F... ¿s. P. E., Ijil, Minerel industry of Alaska in 1939: U.S. Geol.

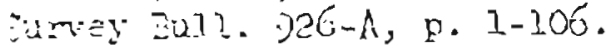

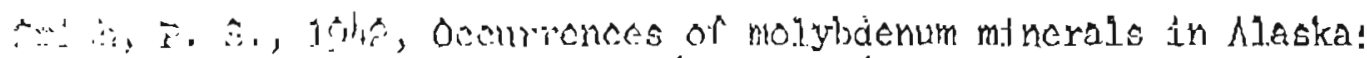

$\because$ 3. Kroc. Sursoy tull. $926-c$, p. 161-210.

An, F. S., 29li2, Mineral induetry of Alaske ir 1940: U.S. Geol. survey 3ull. 933-A, p. 1-102.

3.jsmstrom, 5. I., 1952, Summary or ground-water development in A.laske, 1950: 11.S. Geol. Survey Circ. 169, $37 \mathrm{p}$.

Winte, H. G., iest, W. S., Tolbert, G. F., Nelson, $\Lambda$. F..; and Houston, J. R., 1952, prej.iminary sunnary of reconnaissance for urantun in Nlaske, 19ji: IJA. Cool. Survey Cize. 196, 17 p.

Kumel, Bernhard, 1953, American Triassic coiled nautiloids! U.S. Geol. Survey l'ris'. Paper 250, 10k p.

Rifincon, G. D., and Twenhofel, W. S., 105j, some Jead-zine and zine-

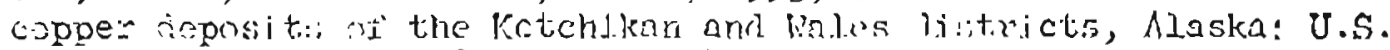
ceol. Su, "i,y Burla. 998-C, p. 5?-34.

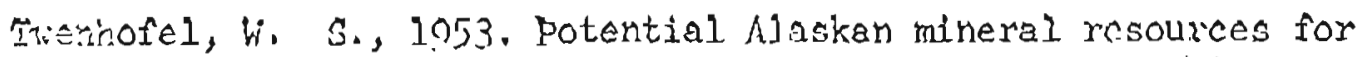
proposed electrocherical and electrometallurric;al industries in the uoper Jyun Canal area, Mlaska: U.S. Genl. Survey Circ. $252,14 \mathrm{r}$. 
Watow, Helmith. Ir., and others, 1953, Proliminaly summary of reconnaissance for uranium and thorium in Alarka, l.252: II.S. Geol. Survey Circ. $21,8,25 \mathrm{p}$.

Vest, W. S., end Benșon, P. D., 1955, Investjegations for radioactive depostts in sontheastern Alaska: U.S. Geol, Survey Buil. 102li-B, p. 25-57.

Byers, F. M., Jr., and seinsbury, C. L., 1956, Tungsten deposits of the Iyder district, Aleska: U.S. Geol. Survey Bull. 3024-F, p. 123-140.

Lohr, E. W., 195T, Chamical character of public water supplies of the larger cities in Niaska, Hawait, ond Puerto Rico, 295 l.? U.S. Geol. Survey hater-5upply Paper IL60-A, p. $2-39$.

sainsbury, C. L., 1957, A geocbemical exploration for antimony in southeasterr hlaska: U.S. Geol. Survey Bull. IC2l-H, p. 163-178. llouston, J. R., Rates, R. G., Velikanja, R. S., and Wedow, Helmuth,
Jr., 195:, Reconnelssance for radioactive deposits in southeastern
Alaska, 1952: U.S. Geol. Survey Bull. $1058-\Lambda, p .31$. Alaska, 1952: U.S. Geol. Survey Bull. 1058- $\Lambda$, p. I-3I.

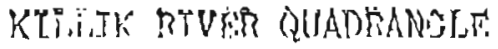

Imlay, R. H., 1955, Chnoctalistlc Jurasstc mollusks irom northern hlaska: ii.n. Ge01. Survey Prof. Psper 27t-D, F. 69-96.

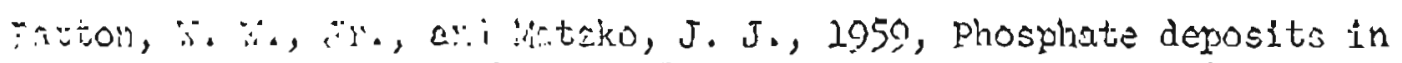

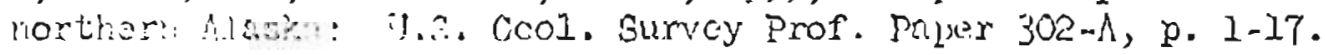

\section{WI:HA QUJARANGLF}

Oots, R. P., 2050, Volcantc activity in the Aleutian arc: U.S. Geol. Survey קil1. 97!:-R, c. 35-49.

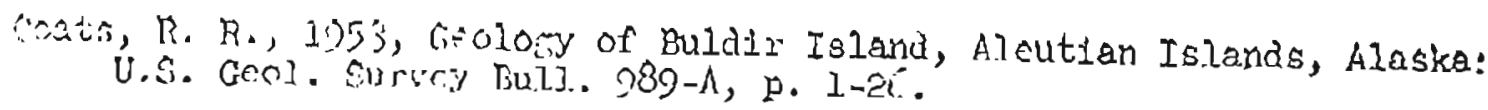

Conts, R. R., $155 r$, Reronmiscance geolony of some western Aleutian J.slands, 4.1eoka: II.S. Creol. Survey Bull. 1028-E, p. 83-100.

snyder, G. L., 1957 , recon rloor structures, northeastern Rat Islands! U.S. Geol. Surve: Bull. 1028-G, p. 161-16\%.

:ilcox, R. E., 1959, some offects of recent volcanic ash falls, with

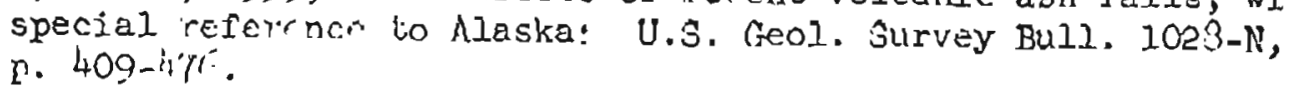




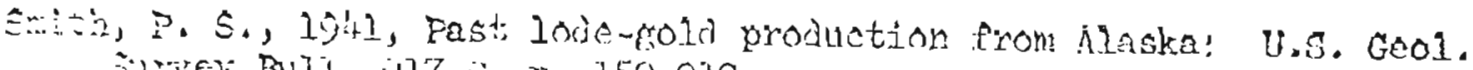
$\therefore$ ANEY Buli. II7-i, p. 159-212.

is:r, $\because$ i., 19:7, themical character or public water supplies of tha larger citis in Alaska, llawaii, an? Puerto Rico, 195l: U.S. sool. Survey :ater-Supply papor $1460-1$, p. 1-39.

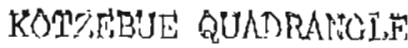

Ceârstrom, D. I., 1952, Suminary of eround-water development in ¿İska, 19;0! U.S. Geol. Survey Cire. 169, $37 \mathrm{p}$.

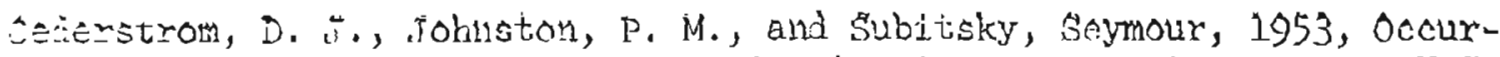
"nce an i relopment of cround water in permefrost regions: U.S. SEol. Gur:ey firc. $275,19 \mathrm{p}$.

:̈phins, D. H., Kinlstrom, T. N. V., and others, 1955, Permafrost mà grounā rater in Alaska! U.S. Geol. Survey Prof. Paper 264-F, r. 113-1 lí́.

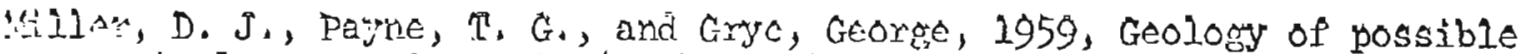
retroleur provinces in Alaska, with an annotated bibliography by F. T. Cobb! j.S. Geol. Survey Bull. 1094, 131 p.

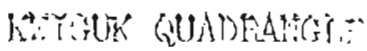

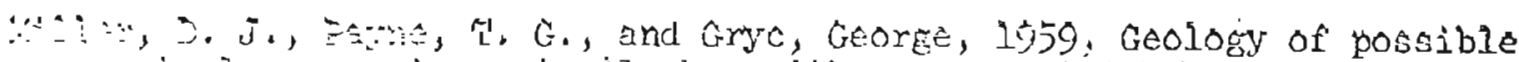

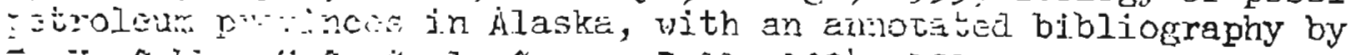

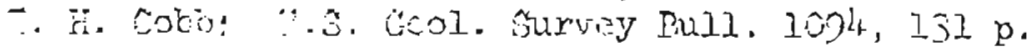

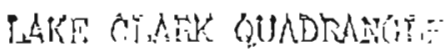

$\therefore$ "n, F. S., 10:L, Hineral industry of niska in 1939! U.S. Ceol. urvey Bul.1. эำ-A, n. 2-106.

Smi: is, P. S., lolite, Occurrences of molybuenum minsals in Alaska! i.s. Geol. Survey Bull. 926-c, p. lól-rio.

Cofite, R. R., 2950, Volcanic activity in the Aleutian arc: U.S. Geol. Survey Bull. 97k-B, p. 35-19.

$\because$ Yhem, R. M., ari ilelson, A. E., 195?, Reconnaissance for radionctive l=posits in ine southern Cook Inlet region, Alaska, 1949: U.S. 'seol. Survey cire. 207, $7 \mathrm{p}$. 


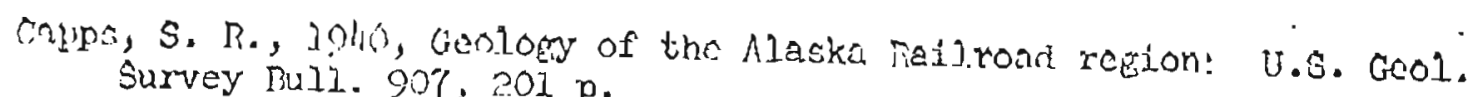

with, I. S., 1.9/1, finelless of EOld from Alaska placers! U.S. Geol. Survey Bult. ?7.0-C, p. 147-27e.

Amith, P. 3., 1.949, Tast lode-cold produciion from N1aska! U.s. Geol. Survey Tuli. 917-6, p. 159-232. Smith, P. S., 194l, Minoral Industry of Alaska in 1939: U.S. Geol.
Survey Bull. $926-A$, p. I-106.

Simith, P. S., 19ita, Mineral industiy of Alaska in 1940: U.S. Geol. Suryey Bu.l. $9.33-1$, p. 1-102.

Now, Helmuth, Jr., Kiliteen, P. I.., and others, 1954, Reconnaissance for radioactjve deposits in eastern interior Alasika, 1946: U.S.
Geol. Survey clrc. $332,36 \mathrm{p}$.

Yedow, Helmuth, Jr., white, M. G., and others, 1954, Reconnalssance for radioactive dcposits in east-central Alaska, 19lig: U.S. Gool. Survey Circ. 335, 22 p.

Caty, W. Mi, Wallace, R. F., Iloare, J. M., and Webber, F. J., 1955, The central Kuskokwim region, Nlaska! U.S. (inol. Survey Prof,
paper $268,23:$..

livins, D. M. Kartritrom, T. N. V., and others, 2955, Pemnafrost

and grouxi wale: in Mlaska: U.B. Grol. Survey Prof. Feper 264-F, p. $123-12 \cdots$

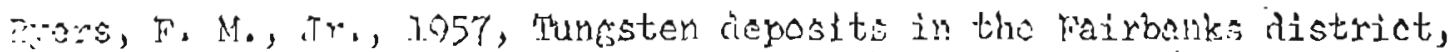
Aliska: U.S. Crol. Survey In]l. 1021t-I, 1. 179-216.

$\because$ I. netroleum provincer. in Alaska, with on annolated bibliography by

F. If. Colii): II.s. Genl. Sumey Bull. log!, $131 \mathrm{p}$.

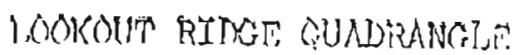

Milicr, D. I., Payne, T. G., and Gryc, Geore, 1950, Geology of possible petroleum provinces in Alaska, with an annotated bibliography by E. H. Cohb: 11.S. Ceol. Survey Bull. Ionk, $131 \mathrm{p}$. 
Cei:arstrom, D. J., 1952, Eumary of eround-wate: livelopment in Alaska, 1950: IJ.S. Geol. Survey Cire. 169, $37 \mathrm{p}$.

Hest, if. S., 1954, Peconnoissance ror radioactive deposits in the lower Yukon-kuskokwin region, Alaska, 195e: U.S. Ceol. Survey Cire. $328,10 \mathrm{p}$.

Miller, D. J., Pajne, T. G., and Gryc, Georete, 1959, Geoloey of possible petroleum provinces in Alaska, with an annotated blbliography by ¿. H. Cobb: II.S. Geol. Survey Full. 1094, $131 \mathrm{p}$.

\section{MEURTITY GUADRANGTIT}

Yoffit, F. H., 1943, Geology of the Nutzotin Mountains, Alaska, with a section on the igneous rocks, by R. G. Wayland: U.S. Geol. Survey Bull. 933-B, p. 103-174.

'iiller, D. J., 1946, Copper defostts of the Nizina district, Mlaska! U.S. Geol. Survey Bull. 9lk-F, p. 93-120.

Van Alstine, R. F., and Black, R. F., 1946, Copper deposits of the Kotsina-Kuskulana district, Alaska: U.S. Geol. Survey Bull. $947-G$, P. 221-14.1.

$\because$ Yaren, R. M., and Ne!son, A. E., 1952, Reconnaissance for radio. active ierouts in south-central hlaska, 1917-lk9: U.S. Gaol.

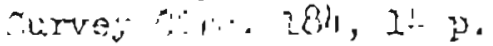

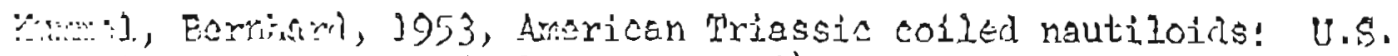
bisol. Sul:ey Trot. Foper 250,104 p.

Anhorel, i. S., 1953: Dotential Alaskan mineral resources for proposei clectrochenical and elcctrometallurgical industries in the unper Tynn Canal aroa, Alaska: U.S. Grol. Survey circ. 25e, it 2 .

Iaffe, H. W., Gottried, Devid, Waring, S. L., and Worthing, H. H., 1959, Iend-alpha agr determinations of accessory mincrals of igneous rocks (1953-195i: 17.S. Geol. Survey Bul1. 1007-5, p. 65-148.

irilier, D. J., payme, F. G., and Grye, George, 1959, Geolosy of possible petroleum provinces ir Alaska, with an ennotated bibliograpiry by

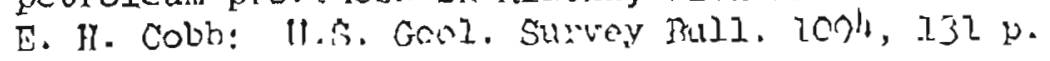




\section{MCLRATR QUANRANGTF}

Smith, P. S., lohl, Tineness of zold from Alaska placers: U.S. Geol. onrvey Duli. 910-C, p. 147-272.

Smith, P. 3., 1941, Mineral industry of Nlaska in 1939: U.S. Geo1. Survey Buili. onfi-A, p. 1.-106.

Smitin, P. S., 19h, Minernl industry of Alaska in 1940: U.5. Geol. Survey Bull. 933-A, p. 1-102.

Cederstrom, D. J., 195\%, Summary of ground-water development in Alaske, 1950: U.r. Geol. Survey Circ. 169, 37 p.

Péwé, T. I., and others, 1953, Multiple taciation in Niask, a progress report: U.S. Geol. Survey Clrc. 289,13 p.

thits, M. G., and Killien, P. L., 1953, Reconnaisosnce for ratioactive deposits in the Jower Yukon-Kuskokwim highlands regton, Klaska: H.S. Geol. Surroy Cire. 255, $18 \mathrm{p}$.

Hopkins, D. M., Karlstrom, T. N. V., and others, 1955, Permafrost and ground water in Nlaska: U.S. Ceol. Survey Prof. Paper 264-F,

\section{MTADF, RTVTR QUADRANGTE}

Macioil, F. C., 1757, Chozoic meratorsils of northem Mlaska:

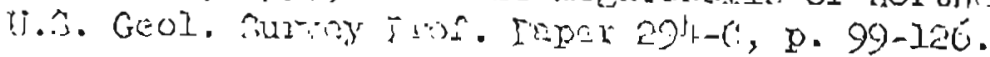

Sollina, F. R., $19 \%$, Toct Wells, Meare and Koolak areas, Alaska,

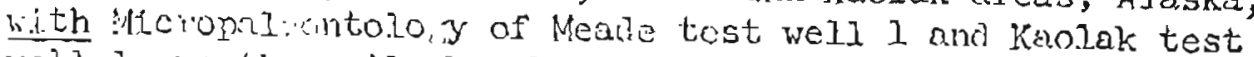

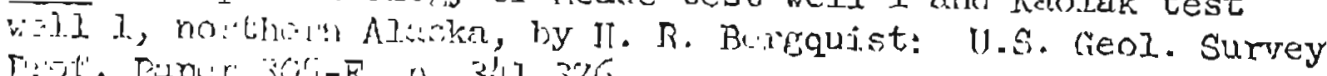

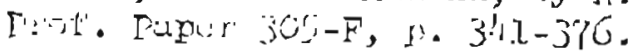

Reed, J.C., 1058, iyphoration of Naval Fetroleum Reserve No. It and

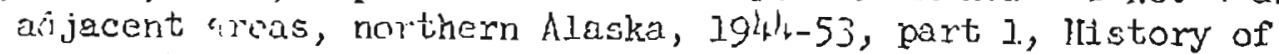
the explo:-ition: U.S. Geol. Survey Prof. Paper 301, l92 p.

Miller, D.J., Payne, T. G., and Grye, George, 1959, Goology of possible petroleum provinces in Alaska, with all annolated hibliography by F. H. Colb: ii.s. Geol. Survey Bull. 1094, 131 p. 


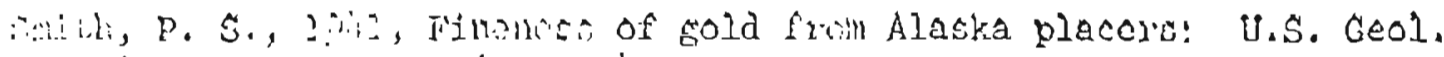

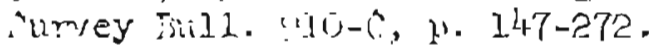

Amith, P. S., i.jir, Past locio-goln ploduction from kiaska! U.S. Geol. iurvay Til11. u? i-c, p. .15?-212.

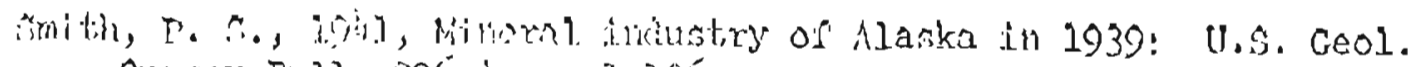
Survey Dul?. geci-k, p. 1-.20í.

Finth, P. S., 29!?, Mineral industry of Alaska in 1940: U.S. Geol. Survey Bull. 933-it, 13. 1-102.

Thite, M. G., anj siciens, 1. M., 1053, Reconnaissance for radiaactive dejosits in the kuy - roman and Nixon Fork ristricts, west-central

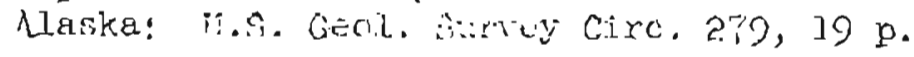

Caty, W. K., Wilocs, R. R., Ioare, T. H., and Webber, E. J., 1955,

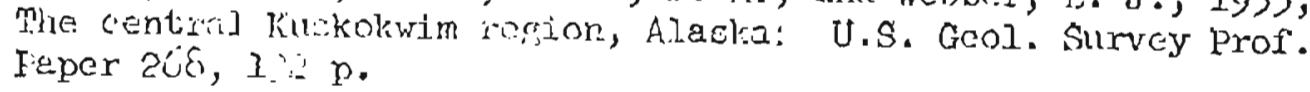

llopkins, D. H., Karlstroin, T. N. V., and others, 2955, permarrost

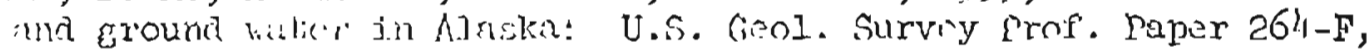
r. $213-1$ iri.

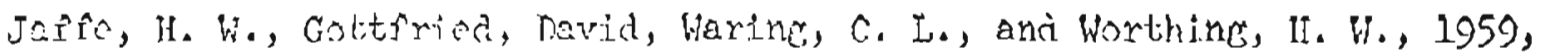
I 2 arl-alpha "he hirminnlions of accessory milnerals of igneous rocks

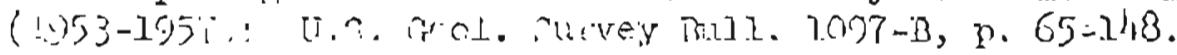

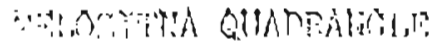

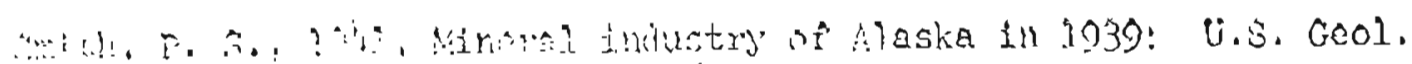

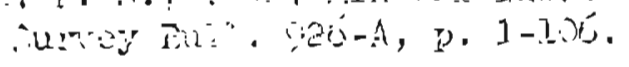

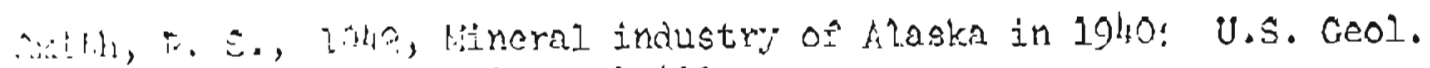

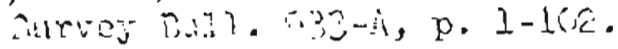

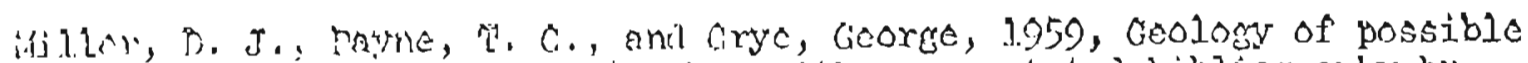
petrolan priviras in hilaza, with an annotated bibliosraphy by F. Il. Colb: I. S. Ceol. Survey Bull. 109\%, 131 p.

\section{MTODITTOH TATAND QUABSAIGTE}

Foll, Futh, 195\%, Foramintiera from carter crock, northeastem Aluska: U.S. Ceol. Survoy Prof. Paper 29k-P, p. 223-235.

Millor, D. J., Payme, T. G., and Grye, George, 1959, Geolory of possible petroleum provinces in Mlaska, with an annotated bibliography by

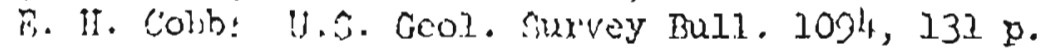


Imlay, R. W., 1955, characteristic Jurasslc mollusks from not thern Alaska: U.S. Geol. Survey Prof. Paper 27l-D, D. 69-96.

Gordon, Mackenz1e, Jr., 1957, Mississippian cephalopods of northern and eastern Mlaska: U.S. Geol. Survey Prof. Paper 283, 61 p.

Imlay, R. W., 1959, succession and speciation of the pelecyood Aucella: U.S. Geol. Survey Prof. Paper 314-G, p. 155-169.

Patton, W. W., JY., and Matzko, J.J., 1959, Phosphate deposits in northern Alaska: U.S. Geol. Survey Prof. Paper 302-A, p. 1-17.

Spetzman, I. A., 1959, Veretation of the Arctic Slope of Alaska:

U.S. Geol. Survey Prof. Paper 302-B, p. 19-58.

\section{MOUNT RATRWEATIER QQUADRANGTES}

Smith, r. S., 19h1, Mineral industry of Alaska in 1939: U.S. Geol. Survey Ful1. 926-A, p. 1-106.

Smith, F.S., 19lt2, occurrences of molybdenum minerals in Alaska:

U.S. Geol. Survey bull. $926-\mathrm{C}, \mathrm{p} .161-2.10$.

Guith, P. S., 1942, Mineral industry of Alaska in 1940: U.S. Geol. Suriey Bull. 933-A, r. 1-102.

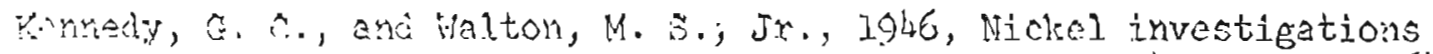
in ociangtern Alasks: U.S. Geol. Survey Bull. 947-C, p. 39-64.

Kanindy, G. :., and Walton, M. S., Ir., 194ó, Geology and associated minera1 ieposit:- of some ultrabasic rock bodies in southeastern Alaske: U.S. scol. Aurry Bull. 947-1), p. 65-8t.

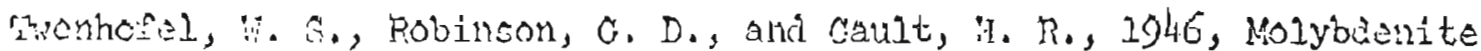
investierions in southeastern Mlaska: U.S. Geol. Survey Bull. $247-B, 2.7-33$.

Tweniciel, W. S., Reed, J. C., and Gates, G. 0., 1949, Some mineral investigations in southeastern Alaska: U.S. Geol. Surrey Bull. $963-\wedge, p \cdot 1-1.5$.

Miller, D. I., Payme, T. G., and Gryc, George, 1959, Geology of possible petroleum provinces in Nleska, with an annotated bibliography by F. II. Coob: U.S. Gool. Survey Bull. 2094, 131 p.

Postman, D. I., 1959, Geology and ore doposits in the Retd Inlet srea, Glacier Bay, Alaska: U.S. Gool. Survey Bull. 1058-3, p. 33-59.

Rossman, D. L., 1.959, Geology and ore deposits of northiestemn Chichazof Island, Alaska: U.S. Geol. Survey Bull. 1058-E, p. 139-216.

Seitz, s. F., 1959, Geology of Geikie Inlet area, Glacter Bay, Alaska: U.S. Cicol. Glivey Bull. 2058-c, p. El.-120. 


\section{MOINA IIAYPRE QUADRANGLT}

Capsi, S. R., 19/:i, Geolong of the Mlaska Railroad recion: U.S. Geol. Eurvey Buil. 907, 201 y.

Srith, P. S., 1019, Finaness of gold from Mlarka placers: U.S. Ceol. Survey Bull. ilo-c, p. $\{47-27 \hat{z}$.

Smith, P. S., 294l, Mineral industry of Alaska in 1939: U.S. Geol. Survey Buil.1. 926-A, p. 1-106.

Moffit, F. H., 1942, Geology of the Gerstle Rdver district, Alaska, with a report on the Black Rapids Glacicr: U.S. Geol. Survey Bull. $926-\mathrm{B}$, p. $207-260$.

Smith, P. S., 1942, occurrences of molybienum minerale in Alaska: U.S. Geol. Sirvey Bull. 926-C, p. 161-210.

Smith, P. S., 19l.2, Mineral industry of Nlaska in 1940: U.5. Geol. Survey Buli. 933-A, p. 1-10e.

Moffit, F. H., 194h, Mining in the northern Copper River refion, Alaska! U.S. Geol. Survey Bull. 9l-3-B, p. 25-47.

Cederstrom, D. J., 1952, Gummary of ground-water development in Nlaske, 1950: 1I.S. Geol. Survey Circ. 169, $37 \mathrm{p}$.

Péwé, 1. I., and othors, 1953, Nultiple glaciation in Nlaska, a progress report: U.S. Geol. Survey Circ. 289, $13 \mathrm{p}$.

Chapman; R. M., and Naunders, R. H., 1054, The Katbleen-Margaret (K-M) copper proupect on the upper Maclaren Fiver, Alaska: U.S. Geol. Surroy Cire. 332, 5 j.

Moffit, F. H., 1954, Geology of the eastern part of the Mlaska Range and adjacent srea: U.S. Gsol. Survey Bull. 989-n, p. 63-218.

Weciow, jlelmuth, $5: .$, Kiliteen, P. I., and others, 195\%, Reconnaissance fou radiouctive deposits in castern juterior Alaska, 1946 : U.S. Geol. Survey cire. $331,36 \mathrm{p}$.

Wahrhaitif, Clycle, and llickox, C. A., 1955, Geology and coal deposits, Jarvis Creek coal rield, Alaske: U.S. Geol. Survey Bull. 989-G, p. 353-367.

Miller, D. J., Payme, T. G., and Gryc, George, 1959, Geology of possible petroleum provinces in Alaska, with an annotated blbliography by E. II. Cobb: U.S. Geol. Survey Bull. 1094, 131 p. 
Coats, R. R., 1950, Volcanic activity in the Aloution are: U.S. Geol. Survey Bull. 972-B, p. 35-40.

Péwé, T. L., and others, 1953, Multiple glaclation in Alaska, a procress report: U.S. Geol. Survey Circ. 289, $13 \mathrm{p}$.

Snyder, G. L., 1954, Fruption of Trident Volcano, Katmai National Monument, Alaske, Februery-June 1953: U.S. Geol. Survey Cire. $318,7 \mathrm{p}$.

Davidson, D. F., and Powers, H. A., 1959, Selenium content of some volcanle rocks from Western United Stetes and Hawaiian Islands: II.S. Geol. Survey Bull. 1084-C, P. 69-81.

Eckhart, R. A, and Plafker, George, 1959, laydite raw material in the Kings River, Sutton, and Lawing areas, Alaska: U.S. Geol. Survey Buil. 1039-C, p. 33-65.

Imlay, R. W., 1959, Succession and speciation of the pelecypod Aucelia: U.S. Geol. Survey Prof. Papex 314-G, p. 155-169.

Kellex, A. S., and Reiser, H. N., 1.959, Geology of the Mount Katmai area, Alaska: U.S. Geol. Survoy Bull. 1058-G, p. 261-298.

Hiller, D. J., Payme, T. G., ani Grye, Georede, 1959, Geology of possible petroleum provinces in Alaska, with an annotated bibliography by

E. 11. Cobb: ij.s. Geol. Survey Bull. 109., lil p.

Ricox, R. H., 2952, some effects of recent volcenic ash falls, with special yerrince to Nlaska: U.S. Gcol. Survej Bull. 1028-N, p. $1.09-476$.

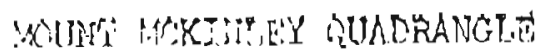

Cappo, S. R., Laci, Geology of the Alaskr Rallrosd region: U.S. Geol. Aurvey Blll. $907,2 j \mathrm{p}$.

Smith, P. S., 19i1, Fineness of gold from Alaska placers! U.S. Geol. sinrey Buli. 910-C, p. $147-272$.

Smith, P. S., 1941, Past lode-gold production from Alasira: U.S. Geol. Survey Iu11. 917-o, p. 159-212.

Snith, P. S., 1941, Mineral 1ndustry of Alaska in 1939! U.S. Geol. Survey Bull. $926-\Lambda, p: 1-106$.

Smith, P.S., 1942, Mineral industry of Alaska 1r 1940: U.S. Geol. Survey Buli. 933-A, p. 1-10

White, D. E., 1942, Antinony deposite of the Stampede Creek area, Kantishra district, Alaske: IJ.S. Geol. Surver Iji1. 936-N, p. $331-3 / 18$. 
Cederstrom, D. J., 1952, Summary of around-water development in Alaska, 1950: U.S. Geol. Survey Circ. 169. $37 \mathrm{m.}$

White, M. G., west, W. S., Tolbert, G. F., Nelson, A. E., and flouston, J. R., 1952, preliminary summary of reconnaissance for uranium in Aleska, 1951: U.s. Geol. Survey Cire. 196, l? p.

Twenhorel, $W$. S., 1953, Potential Alaskan mineral resources for proposed electrochemical and electrometallurgical industrles in the upper Iynn Canal area, Aleska: U.S. Geol. Survey C.trc. 252,14 p:

\section{MOLNI MTCIEESON QULDRANCLLE:}

Tappan, Helen, 1951, foraminifera frum the Alctic slope of Alaska, General introduction and Part 1, Triassic Foraminirera: U.S. Geol. Survey Prof. Paper 236 A, p. 1-20.

White, M. G., 1952, Radioactivity of selected rocks and placer concentrates from northeastem Alaska: U.S. Geol. Survey Circ. 195, $12 \mathrm{p}$.

Imlay, R. W., 1953, Callovian (Jurasste) ammonites from the United States and Alaska, Part 2, Alaska Pentnsula and Cook Inlet reBions: U.S. Geo1. Survey Prof. Papar 219-B, p. 41-108.

Imlay, R. W., 1955, Characteristic Jurassic mollusks from northern Mlaska: U.S. Geol. Survey Prot. Parel eft-D, p. 69-96.

Tapprn, Helen, 2955, Forominifere rrom the Aretic slope of Alaska, Fart 2, Jurassic Foraminifera: U.S. Grol. Survey Prof. Paper $236-B$, p. $21-90$.

Meciteil, F. S., 1957, Cenozoic mezafossils or northern Alaska: U.S. Geol. Survey Prof. Paper 294-c, p. 99-126.

Toda, Futh, 1957, Foraminifera from carter Creek, northeastern Alaska: U.S. Cieol. Survey Prof. Paper 29l.-5, p. 223-235.

Imlay, R. W., 1959, Succession and speciation of the pelecypod Aucella: U.S. Geol. Survey Prof:. Paper 3.2 l $-G$, p. 155-169.

Millex, D. J., Payne, T. G., and Gryc, Georee, 1959, Geology of possible petroleum provinces in Alaska, with an annotated billiography by E. H. Cobb: U.S. Geol. Survey Bull. 1004, 131 p.

Patton, W. W., Jr., and Matzko, J. J., 1959, Phosphate deposits in

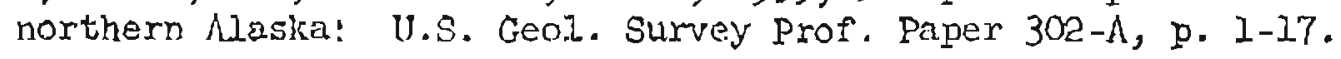

Spetzman, L. A., 1959, Vegetation of the Aretic Slope of Alaska:

U.s. Geol. Survey Prof. paper 302-B, D. $19-58$. 
Miller, D. J., Payna, I. G., and Gryc, George, 1959, Geology of posetble petroleum provinces in flaska, with an annotated bibliography by

E. II. Cobb: U.S. Gc:01. Survey Buli. 1094, 131 p.

\section{NABESUA QUADRANCLE}

Moffit, F. H., 194I, Geology of the upper fetling River district, Aleska: U.S. Geol. Survey Bul1. 917-B, P. 115-157.

Sinth, P. S., 19lkl, Fineress of eold from Alaska placers: U.S. Geol. Survey Buld. 910-C, p. 147-272.

Smith, P. S., 1941, Past lode-gold production from Alaska! U.S. Geol. Survey Bull. 917-C, p. 159-212.

Smith, P. S., 1941, Mineral Industry of Alaska in 2939: U.S. Geol. Survey Bull. 926-A, p. 1-106.

Sulth, P. S., 194h, Occurrences of molybdenum merals in Aloska: U.8. Geol. Survey Buil. 926-C, p. 161-210.

Smith, P. S., 1942, Mineral industry of Alaska in 1940: U.S. Geol. Survey Bul1. 933-A, D. 1-102.

Moffit, F. H., 1.943, Ceoloky of the Nutzotin Mountains, Alaska, with a section on the igneous rocks, by R. G. Wayland: U.S. Geol. Survey Pulz. 933-3, 2. 103-174.

Vayland, P. G., 194.3, Cola depoeits near Mabesna: U.S. Geol. Survey Bul1. 933-8, 2. 175-199.

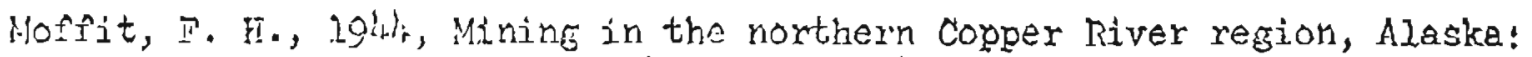
U.S. Geol. Survey Bull. 943-B, p. 25-47.

Coderstrom, D. T., 1952, sumary of ground-water development in Mlaska, 1950: U.S. Geol. Survey Circ, 169, 37 p.

Twenhofel, W. S., 1953, Potentiel Alaskan mineral resources for proposed electrochemical and electrometallurgical industries in the upper Lyan Canal area, Alaska! U.S. Geol. Survey Circ. 252, 14 p.

Wedow, Helmuth, Jr., and others, 1953, preliminary summary of reconnaissance for uraniur and thortum in Alaska, 1952: U.S. Geol. Survey C1re. $248,25 \mathrm{y}$.

Mofist, F. H., 1954, Geology of the eastem part of the Alaska Range and adjacent area: U.S. Geol. Survey Bull. 989-D, p. 63-218.

Nelson, A. Er, West, W. S., and Matzko, J. J., 1954, Reconnalssance for radioactive deposits in eastern Alaska, 3952: U.S. Geol. Survey circ. 348, 21 p. 


\section{NABESNA. QUADRANGLË}

Hedow, Helmuth, Jr., Killecr, P. L., and others, 1954, Reconralssance for radioactive deposits in eastern interior Alaska, 1946: U.S. Geol. Surrey Circ. 331, 36 p.

Millex, D. J., Payme, T. G., and Gryc, Georte, 1959, Geoloey of posstble. petroleum provinces in Alaska, with an annotated bibliography by E. H. Cobb: U.S. Gcol. Survey Bull. 1094, 231 p.

\section{NANTFTK OLIA!RANGLE}

Cederstrom, D. J., 1952, summary of Eround-water development in Alasks, 1950: U.S. Geol. Survey Circ. 169, 37 p.

Péwé, T. I., and others, 1953, Multiple glaciation in Alaska, a progress report: U.S. Geol. Survey Circ. $289,13 \mathrm{p}$.

Hopkins, D. M., Karlstrom, T. N. V., and others, 1955, Permafrost and ground water in Alaska: U.S. Geol. Survey Prof. Paper 264-F, p. $113-146$.

Keller, A. S., and Reiser, H. N., 1959, Geology of the Mount Katmai area, Alaska: U.S. Geol. Survey Bull. 1058-G, p. 261-298.

\section{MOATAK QUADRANGLE.}

Gorion, Mackenzie, Jr., 1957, Mississippian cephelopods of northern and eastern Alaska: U.S. Geol. Survey Prof. Peper 283, 61 p.

litiler, D. J., Payne, T. O., and Grye, George, 1959, Geology of poseible petroleum provinces in Alaska, with an annotatel bibliography by F. H. Cobb: U.S. Geol. Survey Bull. 109h, 131 p. 
Sinith, P. S., 3:11, Fineness of gold from Alaska placers: U.S. Geol. Survey Bull. $910-C$, p. $147-272$.

Smith, 9. S., 1941, Past lode-gold production from Algska! U.S. Geol.

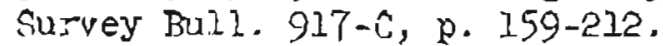

Smith, P. S., 1.9h1, Mineral industry of Alaske in 1939: U.S. Geol. Survey Bull. 926-A, P. 1-106.

Smith, P. S., 1942, Occurrences of molybdenum mitrerals in Aleska! U.S. Geol. Survey Bull. 926-C, p. 161-210.

Smith, P. S., 1942, Mineral industry of Alasica in 1940! U.S. Geol. Survey Buld. 933-4, p. 1-102.

Hopkins, D. M., and Sigefoos, R. S., 1951, Frost action and vegetation patterns on Seward Peninsula, Alaska: U.S. Geol. Survey Bull. 974-C, p. $51-101$.

Cederstrom, D. J., 1952, summary of ground-water development in Alaske, 1950: U.S. Geol. Survey Circ. 169, 37 p.

White, M. G., West, W. S., Tolbert, G. E., Nelson, A. E..; and Houston, J.R., 1952, Preliminary summary of reconnaissance for urantur in Alaske, 1951: U.S. Geol. Survey Circ. 196, I7 p.

Péwé, T. L., ama others, 1953, Multiple glaclation in Alagke, a progress report: U.S. Geol. Survoy Circ. 289, 13 p.

White, M. G., West, H. B., and Matzko, J. J., 1953, Reconnalssance for radioactive depoeits in the vicinity of Teller and Cape Nome, seward Penirsula, Alaske, 1946-hry: U.S. Geol. Surrey Circ. 244, $8 \mathrm{p}$.

Hopkins, D. M., Karlstrom, T. II. V., and others, 1955, Permafrost snd ground water in Alaska! U.S. Gen1. Survey Prof. Paper 264-F, D. $113-146$.

Lohr, E. W., 1957, Cherical character of public vater supplies of the larger cities in Alaska, Hawaii, and puerto Rico, 1954: U.S. Geol. Survej tiater-Supply Paper 1460-A, p. 1-39.

MacNeil, F. S., 1957, Cenozoic megafossils of northern Alaska: U.S. Geol. Survey Prof'. Paper 294-C, p. 99-126.

Trumbuli, James, Lymar, Johr, Pepper, J.F., and Fhomasson, E.M., 1958, An introduction to the geology and mineral resources of the continental shelves of the Americas: U.S. Geol. Survey Bull. $1067,92 \mathrm{p}$.

Miller, D. J., Payne, T. G., and Gryc, George, 1959, Geology of possible petroleum provinces in Alaska, with an annotated bibliography by E. H. Cobb: U.S. Geol. Survey Buli. 1094, 131 p. 
WOPTON BAY QUADRANGIT:

Smith, P. S., 20!1五, finelless of gold from Alaske placers: U.S. Geol. Survey Bull. 910-C, p. 147-272.

Smith, P. S., 1941, Mineral industry of Alaska in 1939: U.S. Geol. Survey Bull. 9e6-A, p. 1-106.

Smith, P. S., 1942, Mineral industry of Alaska in 1940: U.S. Geol. Burvey Bull. 933-A, p. 1-1.02.

West, W. S., 1953, Reconnaissance for radioactive deposits in the Darby Mounteins, Seward Peninsula, Alaska, 1948: U.S. Geol. Survey Cire. 300, 7 p.

Miller, D. J., Payme, T, G., and Grye, Ceorye, 1959, Geolory of possible petroleum provinces in Alaska, with an annotated bibliography by E. H. Cobb: U.S. Geol. Survey Bull. 1094, 131 p.

\section{NOP.ATO GUADRANGLE}

Cederstrom, D. Y., 1952, Summary of ground-water development in Alaska, 1950: U. 0 . Geol. Survey Circ. 369, $37 \mathrm{p}$.

Milier, D. J., Payne, T. G., and Gryc, Georee, 1959, Geology of possible petroleum provinces in Alaska, with an annotated bibliography by F. II. Cobb: U.S. Geol. Survey Bull. logh, $13 \mathrm{l}$ p.

MIMIVAK TSLAND QUADRANGLE

Mtlior, D. J., Payre, T. G., and Gryc, George, 1959, Geology of posstble petroleum piovinces in hlaska, with an annotated bibliography by

E. H. Cobb: U.S. Gool. Survey Bull. 1094, 131 p.

\section{INISHAGAK BAY QUADRAIVGIE}

Cederstrom, D. T., 1952, Summery of ground-water development in Alasko, 1950: U.S. Geol. Survey Circ. 169, 37 p.

Milier, D. J., payme, T. G., and Grye, George, 1959, Geology of possible petroleum provinces in Alaska, with an annotated bibliography by

E. H. Cobb: U.S. Geol. Survey Bull. 1094, 131 p. 


\section{ophir suAdPAMGL:}

Smith, P. S., 1911, Past lode-golo profiktion from Alaska: U.S. Ceol. survay Bull. 917-c, p. 159-212.

Smith, P. S., 1941, Mineral industry of Alaska in 1939: U.S. Geol. Survey Bull. 926-A, p. 1-106.

Smlth, P. S., 1942, Mineral industiy of Alasko in 1910: U.S. Geol. Survey Bull. 933-A, p. 1-102.

White, M. G., and Killeen, P. L., 1953, zeconnaissance for radioactive deposits in the lower Yukon-Kuskokulm highlands region, Alaska: U.S. Geol. Survey Circ. 255,18 p.

\section{FFTETSRURG QUADRASGE}

Smith, P. S., 1941, Past lode-gold production from Alaska! U.S. Geol. Survey Bull. 937-C, p. 159-212.

Smith, P. S., 1941, Mineral Industmy of Alaska in 1939! U.S. Geol. Survey Bull. 926-1, p. 1-106.

Smith, P. S., 1942, Occurrances of molybdenum metherais in Alaska: U.S. Geol. Survey Bull. 926-C, p. lel-2lo.

Kennedy, G. C., and lelton, M. S., T*., 19!5, Ceology and associated mineral apposits of some ultrabasic rock ockles in suthestern Alaska: U.S. Geol. Survey Bul1. 9417-D, p. 65-84.

Mventofel, W. S., Robinson, G. D., ans Geult, H. R., 1946, Molybdenite invectigations in southeastern Alrska: U.S. Geol. Survey Bull.

Trenhofel, W. S., Reed, J. C., and Gotes, C. 0., 19k9, some mineral investigations in southeastern 4leske: U.S. Geol. Survey Bull. $963-\mathrm{A}, \mathrm{p}, 1-1.5$.

Bressler, C. T., 1950, Gernet deposits near irangell, southeastem Alaska: U.S. Geol. Survey Bull. 963-C, p. 81-93.

Cederstron, D. J., 1952, Summary of Eround-water development in Alaska, 2950! U.S. Ceol. Survey Cire. 169, 37 p.

Gault, H. RA, Roseman, D. Z., Flint, G. U., Jr., and Ray, R. G., 1953, Some lead-zinc deposits of the Mrangall district, Alaska: U.S. Geol. Survey Bull. 998-B, p. 25-59.

Kummel, Bernhard, 1953, Amerlcan Triassic colled nautiloids! U.S. Geol. Survey Prof. Paper 250, 101. p. 


\section{PETERSBURG QUADRANGLE}

Thentbofel, W. S., 1953, potential Alaskan mineral resources for proposed electrochemical and electrometallurgical industries in the upper Lynn Canal area, Alaska: U.S. Geol. Survey Circ. 25P. $14 \mathrm{n}$.

Wedow, Heimuth, Jr., and others, 1953, Preliminary summary of reconnaissance for uranium and thorium in Alaska, 1952: U.S. Geol. Survey Circ. $248 ; 15$ p.

Lohr, E. W., 1957, Cherical character of public water supplies of the larger cities in Alaska, Hawaii, and Puerto Rico, 1954! U.S. Geol. Survey Water-Supply Paper 1460-A, p. 1-39.

Houston, J. R., Bates, R. G., Velikanje, R. S., and Wedow, Helmuth, Jr., 1958, Reconnaissance for radioactive deposits in southeastern Alaska, 1952: U.S. Geol. Survey Bull. 1058- $\Lambda$, p. 1-31.

Milier, D. J., Payme, T. G., and Gryc, George, 1959, Geology of possible petroleum provinces in Alaska, with an annotated bibliography by F. H. Cobb: U.S. Geol. Survey Bull. 109l. 121 n.

\section{PUIT,IP SHTTH MOUNTATINS QUADRANCLE}

Péwé, T. L., and others, 1953, Nultiple glaciation in Alaska, a prosress report: U.S. Geol. Survey Circ. 289, 13 p.

Imlay, R. H., 1955, Characteristic Jurassic mollusks from northern Mlaska: U.S. Geol. Survey Pror. Puper 274-D, p. 69-96.

Imlay, R. W., 1959, Succersion and speciation of the pelecypod Aucella: U.S. Geol. Survey Prof. Paper 314-G, p. 155-169.

POINT HOPE QUADRANGES

Cederstrom, D. J., 1952, Summary of ground-water development in Alaska, 1950: U.S. Geol. Survey Circ. 169, 37 p.

Gordon, Mackenzie, Jr., 3957, Mississippian cephalopods of northem and eastem Alaska: U.S. Geol. Survey Prof. Paper 283, 61 p.

\section{POOIN1 LAY QUADRANGLF}

MacNeil, F. S., 1957, Cenozoic megafossils of northern Alaska:

U.S. Geol. Survey Prof. Paper 294-C, p. 99-126. 
Gulld, P. W., and Balsley, J. R., Jr., 19l+2, Ciromit.e deposits of Red Cluff Bey and vicinity, Baranof Isl.are, Al.acke: U.S. Geol. Survey Pull. 936-G, D. L7L-187.

Reed, T. C., and Gates, G. 0., 1942, Nicke?--opper deposits at Snipe Bay, Baranof Islani, Alaska: U.S. Ccol. Survey Bull. 936-M, p. $32 . \mathrm{l}-330$.

Kennedy, G. C., and Walton, M. S., Ir., 1946, Geology and associated mineral depostts of some ultrabasic rock bodits in southeastern Alaska: U.S. Geo1. Survey Brill. 947-D, p. 65-84.

Twenhofe1, W. S., Reed, J. C., and Gates, G. 0., 19!9, some mineral investigations in southeastern Alaska: U.S. Geol. Survey Bull. $963-A$, p. $1-45$.

Twenhofel, w. S., 1953, Potential Mlaskan mineral resources for proposed electrochemical and electrometallurgical industries In the upper Lym Canal area, Alaska! U.S. Geol. Survey Circ. 252, 14 p.

West, W. S., and Benson, P. D., 1955, Investigations for radioactive deposits in southeastern Alaska: U.S. Geol. Survey Bull. 1024-B,
p. 25-57.

Sainsbury, C. L., 1957, Some peghatite deposits in southeestert Aloska: U.S. Ceol. Survey Bull. 1024-G, p. 141-161.

Miller, D. I., Payne, T. G., and Gryc, Georâ, 1959, Geology of possible petroleum provinces in Alaska, vith an znnotated bibliography by E. H. Cobb: U.S. Geol. Survey Bull. 1\}y.s, 131 p.

PORT MOELTER QLADRATHË

Smith, P. S., 1941, Past lode-gold production from Alaska! U.S. Geol. Survey Bull. ?I7-C, p. 159-212.

Smith, P. S., 19li, Mineral industry of Alaska in 1939: U.S. Geol. Survey Bull. 926-A, p. 1-106.

Coats, R. R., 1950, Volcanic activity in the Aleutian are: U.S. Geol. survey Bull. 97k-B, p. 35-49.

Kennedy, G. C., and Waldron, H. H., 1955, Geology of Pavlof volcano and vicinity, Alaska! U.S. Geol. Survey Bull. 1028-A, p. 1-19.

MacNe11, F. S., 1957, Cenozoic megafossils of northern Alaska:

U.S. Geol. Survey Prof. Paper 294-C, p. 99-126.

Miller, D. J., Payre, T. G., and Grye, George, 1959, Geology of possible petroleum provinces in Alaska, with an annotated bibliography by E. H. Colsb: U.S. Geol. Survey Bull. 1394, 131 p. 


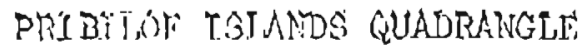

Barth, T. F. W. 1956, Geolocy and petrology of the Pribilof Islands, Alaska: U.S. Geol. Survey Bull. 1028-F, p. 101-160.

MacNeil, F. S., 1957, Cenozoic megafossils of northern Alaska: U.S. Geol. Survey Prố. Paper 294-C, p. 99-126.

\section{PRTNCE RUPERI QUADRANGLE}

Sainsbury, C. L., 1957, Some pegmatite deposits in southeastern Alaska: U.S. Geol. Survey Bull. 1024-G, p. 141-161.

\section{RAT ISIMNDS QIJADRÁNGLE}

Coats, R. R., 1950, Volcanic activity in the Aleutian arc: U.S. Geol. Survey Bull. 974-B, p. 35-49.

Coats, R. R., 1956, Reconnalssance geology of some western Aleutlan Islands, Alaska: U.S. Geol. Survey Bull. 2028-E; p. 83-100.

MacNeil, T.S., 1.957, Cenozoic megafossj.ls of northern Alaska: U.S. Geol. Survey Prof. Faper 294-C, P. 99-126.

Snycier, G. L., 2957, Ocean floor structures, northeastern Rat Islands! J.S. Gsol. Survey Bull. 1028-G, p. 161-167.

Todd, Ruth, 1957, Foraminifera from Carter Creek, northeastern Mlaska: U.S. Geol. Survey Prof. Paper 294-F, p. 223-235.

Couts, R. R., 195\%, Gcologic recomnaissance of Semisopochnoi Is land, hestern Aleutian Islands, Alaska: U.S. Geol. Survey Bull. 1028-0, p. $477-519$.

Travicson, D. F., and Porers, II. A., 1959, Selenium content of some volcanic rocks from hestern United States and Hawaiian Islands: U.ふ. Geol. Survey Bull. 1084-C, p. 69-81.

Helsom, W. T., 1959, Geology of Segula, Davidof and Khvostof Islands, Alaska: U.S. Geol. Survey Bull. 1028-K, p. 257-266.

Snyder, G. L., 1959, Geology of Iittle Sitkin Island, Alaska: U.S. Geol. Survey Ibull. 1028-11, p. 169-210. 
smith, P. S., 19t1, Finenes of fold from Mlaske piacers: U.S. Geol.

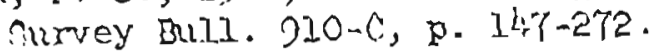

Snith, P. S., 1941, Mineral industry of A.IEska in 1939: U.S. Geol. Survey Bull. 926-A, p. 1-106.

Simith, P. S., 1942, Mineral industiy of Aleska in 1940: U.S. Geol. Survey Bull. 933-A, p. 1-102.

Cederstrom, D. J., 1952, Summary of ground-rater development in Alaska, 1950: U.S. Geol. Survey Cire. 169, 37 p.

White, M. G., and stevens, J.M., 1953, Reconna1ssance for radioactive deposits in the Ruby-poorman and ilixon Fork districts, west-central Alaska: U.S. Geol. Survey Cire. 279,29 p.

Gottfried, David, Jafie, li. W., and Sentele, F. E., 1959, Evaluation of the lead-alpha age determinations of accessory minerals of igneous rocks: U.S. Geol. Survey Bull. 109?-A, p. 2-6́3.

Jeffe, II. W., cottfried, Dev1d, Waring, C. L., and Worthing, H. W., 1959, lead-alpha age determinations of accessory intnerals of igneous rocks (1953-1957): U.S. Geol. Survey Bull. 1097-B; p. 65-148.

Miller, D. J., Payne, T. G., and Gryc, George, 1959, Geology of possible petroleum provinces in Alaska, with an amotated bibliography by E. II. Cobb: U.S. Geol. Survey BuIl. I004, 131 p.

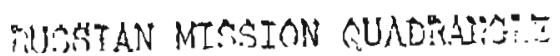

smith, r.s., 19h1, Hinaners of pold fri... Aasks placers? U.S. Geol. iursey BuIl. 110-C, p. $147-272$.

Smith, P. S., 1941, past iode-gold production from Alaska! U.S. Geol. Survey Dull. (327-C, p. 159-212.

Simith, T. S., 19kj. Mincral industry of Alaska 1t 1939: U.S. Geol. Survey Bull. $926-A$, p. 1-106.

Snith, P. S., 194e, Occurrences of molybdenum minerals in Alaska: U.S. Geol. Survey Bull. 926-C, p. .lél-210.

Smith, P. S., 1942, Mineral industry of Alaska 1n 1940: U.S. Geol. Survey Bull. 933-A, p. 1-102.

Cederstrom, D. J., 1052, Summary of ground-water development in Nleska, 1950: It.s. Ceol. Survey C.re. 169, 37 p. 


\section{RUSSIAN MISSION OQUAORANGLE}

Wedow, Helmuth, Jr., and others, 1953, Preliminary summary of reconnaissance for uranium and thorium in Nlaska, 1952: U.S. Geol. Survey Circ. $248,15 \mathrm{p}$.

liest, $W . S ., 1954$, Reconnaissance for radjoactive deposits in the lower Yukon-kuskokwim region, A.laska, 1952! U.S. Geol. Survey cire. 328,20 p.

Ceiy, W. M., Vallace, R. E., Hoare, J. M., and Nebber, E. J., 1955 , The central KuskokwIm region, Alaska: U.S. Geol. Survey Prof. Paper 268, 132 p.

\section{SARAVATYERTOK QUATRAWGLE}

Páké, T. L., and others, 1953, Mutiple glaciation in Alaska, a progress report: U.S. Geol. Survey Circ. 289, 23 p.

Imlay, R. W., 2955, Characteristic Jurassic mollusks from northern Alaska: U.S. Geol. Survey Prof. Paper 27t-D, p. 69-96.

Gordon, Mackenzie, Jr., 1957, Mississippian cephalopods of northem and eastern Alaska: U.S. Geol. Survey Prof. Paper 283, 61 p.

Imlay, R. W., 1959, Succession and spectation of the pelecypod Aucella: U.S. Geol. Survey Prof. Paper 314-G, p. 355-169.

:11er, D. J., Fayne, T. G., and Grye, George, 1959, Geology of possible petroleum provinces in Alaska, with an annotated bibliography by E. II. Cobb: 1J.S. Geol. Survey Bull. 1094, 131 p.

Zquton, W. M., Tr., and Matzko, J. J., 1959, Phosphate deposits in northern Alaska: U.S. Geol. Survey Prof. Papel 302-A, p. $1-17$.

\section{SAJNT TAARRENCE QYUEADRANG\}E}

Barth, T. F. U.. 1956, Geology and petrology of the Pribilof Islands, Mlaske: U.S. Geol. Survey BuIl. 1028-F, p. 201-160.

Yacteil, F. S., 1957, Cenozoic mecafosslis of northern Alaska:

U.S. Geol. Survey Prof. Paper 294-C, p. 99-126. 
Ceterstrom, D. J., J.952, Summary of ground-water development in Alaska, 1950: U.s. Geol. Survey Cire. 169, 37 p.

Milier, D. J., Payre, T. G., and Gryc, George, 1959, Geology of possible petroleum provinces in Alaska, with en ennotated bibliography by

E. H. Cobb: U.S. Geol. Survey BuIl. 1094, 131 p.

\section{SAMATCA TELAND QIUADRANGLE}

Coats, R. R., 1950, Volcanic activity in the Aleutian arce U.S. Geol. Surviy Bull. $974-B$, p. 35-4.9.

Byers, U.S. Geol. Survey Bulti. 1028-L, D. $267-369$.

\section{AWGUAM QUADHANGLF.}

conts, R. R., 1950, Volcanic activity in the Alcutian arc: U.S. Geol. Survey Buli. 97 tr-B, p. 35-49.

\section{SEYMIIK QUADNANGLE}

Hedow, Helmuth, Ir., and others, 1953, Preliminary summary of reconnaissance for uranilum and thorium in Alaska, 1952: U.S. Geol. Survey Circ. El:g, $15 \mathrm{p}$.

$\because$ ilin. 3. J., Fayne, T. G., and Gryc, George, 1959, Geology of possible petroleum provinces in Alaska, witn an annotated blbliography by T.. H. Cobb! U.S. Geol. Survey Bull. 1094, 131 p.

\section{SFIDOVIA GUADRANGTA}

Capps, S. R., 19:3, Geolocy of the Mlasks Railroad region: U.S. Geol. Survey Bull. $907,201 \mathrm{p}$.

Guith, D. S., 1941, Past lode-gold produetion from Alaska! U.S. Geol. Aurvey Bull. 917-C, p. 159-212.

Smith, P. S., 1941, Mineral industry of Alaska in 1939: U.S. Geol. Survey Bull. 926-A, p. 1-106.

Gulld, P. W., 1942, Chromite deposits of Kenai Peninsula, Alaska: U.S. Geol. Survey Bull. 931-G, p. 139-175

Smith, P. S., 19i42, Mineral industry of Alaska in 1940! U.S. Geol. Survey Bull. 933-A, p. 1-102.

Bemes, F. F., 1951, Preliminary report on coal déposits near llomer, Alaska, in Barnes, F. F., and others, coal investigations in southcentral Klaska, 19hl-46: U.S. Geol. Survey Bull. 963-E, p. 202208. 


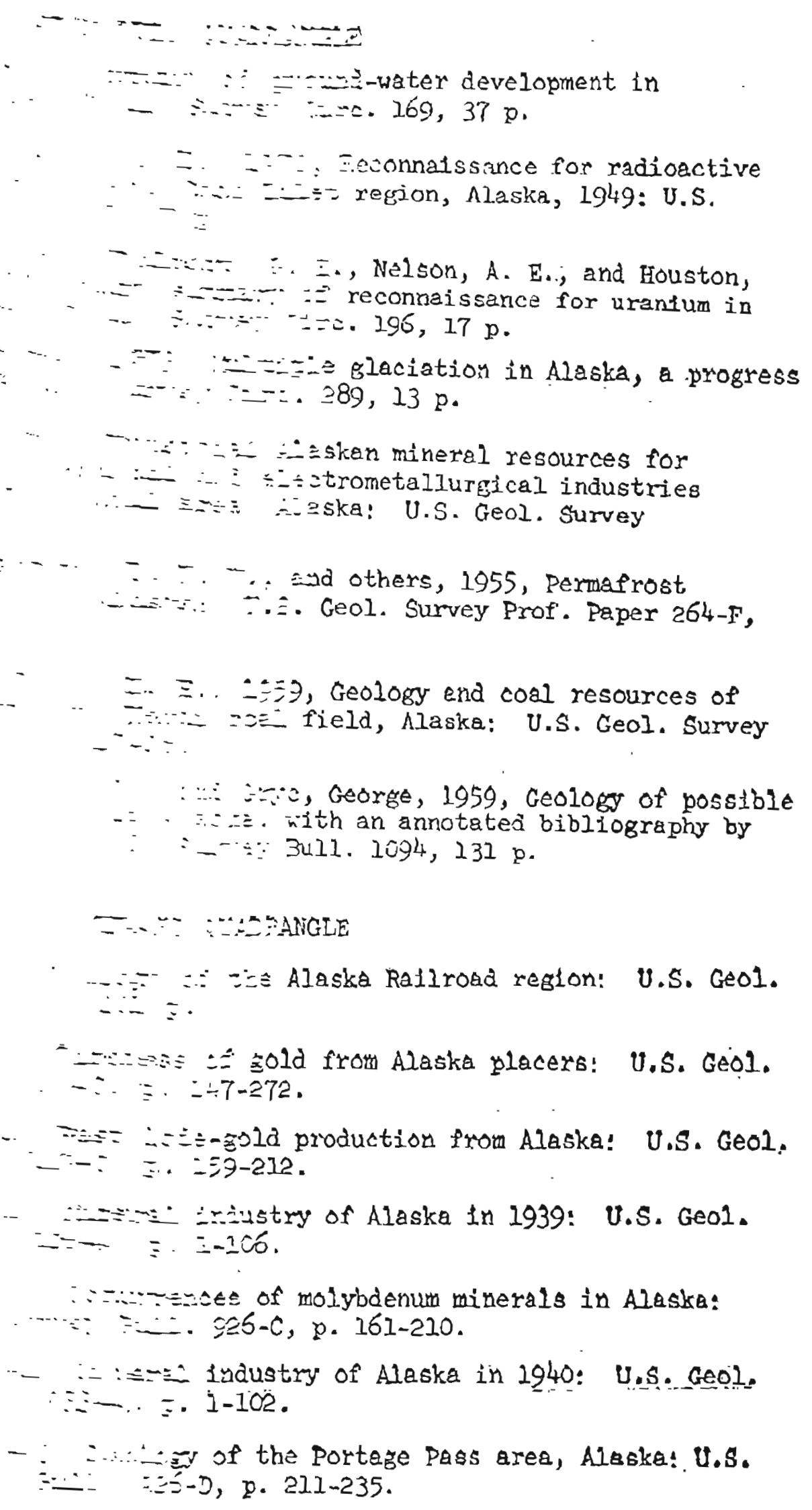


Stepansson, Karl, and Moxham, R. M., 1946, Copper Bullion claims, The Cove, Kright Island, Alaska: U.S. Grol. Survey Bull. 947-E, p. 85-92

Moffit, F. K., and Fellows, R. E., 1950, Copper deposits of the Prince illiliam Sound district, Alaska: U.S. Ceol. Survey Bull. 963-8, p. $47-80$.

Cederstrom, D. J., 1952, Summary of ground-water development in Alaska, 1950: U.S. Geol. Survey Circ. 169, 37 p.

White, M. G., Hest, W. S., Tolbert, G. E., Nelson, A. E..; and Houston, J. R., 1952, Prellminary summary of reconnaissance for uranium in Alakka, 1951: U.S. Geol. Survey Circ. 196, 17 p.

Pewé, T. I., and others, 1953, Mitiole glaciation in Alaska, a progreas report: U.5. Geol. Survey Clirc. 289, 13 p.

Moffit, F. H., 1954, Geology of the Prince william Sound region, Alaska: U.S. Geol. Survey Bull. 989-E, p. 225-310.

Plafker, George, 1955, Geologic investigations or proposed power sites at Cooper, Grant, Ptamigan, and Crescent Lakes, Alaska! U.S. Geol. Survey Bul1. 1.031-A, p. 1-23.

Stejer, F. A., 1956, Pyrlte deposits at Horseshoe Bay, Eatouche Island, Aleska! U.S. Geol. Survey Bull. 1024-E, p. 107-122.

Lohr, F. H., 1;\%7, Chemical character of public water supplies of the large: cities in Alaska, Hawait, and Puerto Rico, '1954! U.S. Geol. Surey liater-Supply Paper 1460-A, p. I-39.

Eskhart, R. A., and Plafker, George, 1959, Haydte raw material in the Kings Rive:, Sutton, and Lawing areas, Aleska: U.S. Geol. Survey Bul1. $3039-C$, p. 33-65.

\section{SHISTMAREFT QUADRAIMGT}

M11er, D. J., Payne, T. G., and Gryc, George, 1959, Geology of posstble petroleur provinces in Alaska, with an annotated bibliography by E. H. Cobb! U.S. Geol. Survey Bull. 1094, 131 p.

\section{SHTNGNAK QUAJRANGLE}

Smith, P. S., iglis, Mineral industry of Alaske in 1939: U.S. Geol. Survey Buili. 926-A, p. 1-106.

Smith, F. S., 1942, Mineral industry of Alaska in 1940! U.S. Geol:Survey Bull. 933-A, p. I'-10ä.

Miller, D. J., Payne, T. G., and Gryc, George, 1959, Geology of posatble petroleum prorinces in Alsska, with an annotated biblioglaphy by E. H. Cobh: U.S. Geol. Survey Bull. 1094, 131 p. 


\section{SITKA GUADRANGLE}

Reed, J. C., and Coats, R. R., 1941, Geology and ore deposits of the Chichagof wining district, Alaska: U.S. Geol. Survey Bull. 929, 148 p.

Sulth, P. S., 1941, Past lode-gold production from Nlaska: U.S. Geol. Survey Bull. 917-C, p. 159-212.

Smith, P. S., 1941, Mineral industry of Alaska in 1939: U.S. Geol. Survey Bull. 926-A, P. 1-106.

Guild, P. W., and Balsley, J. R., Jr., 1942, Chromite deposits of Red Bluff Bay and vicinity, Baranof Island, Alaska: U.S. Geol. Survey Bull. 936-G, p. 171-187.

Pecora, W. T., 1942, Nickel-copper deposits on the west coast of Chichagof Island, Alaska: U.S. Ceol. Survey Bull. 936-I, p. 221-243.

Reed, J. C., and Dorr, J.V. N., 2d, 1942, Nickel deposits of Bohemia Basin and vicinity, Yakobi Island, Alaska: U.S. Geol. Survey BuII. 931-F, P. 105-138.

Srith, P. S., 1942, Occurrences of molybdenum minerals in Alaske! U.S. Geol. Survey Bull. 926-C, p. 161-210.

Smith, P. S., 1942, Mineral industry of Alaska in 1940! U.S. Geol.
Survey BuI1. $933-A$, p. $1-102$.

Kennedy, G. C., and Walton, M. S., Jr., 1946, Nickel investigations In southeastern Alaska: U.S. Cool. Survey BuII. 947-C, p. 39-64.

Kenmedy, G. C., and Valton, M. S., Jr., 19L6, Geology and associated mineral deposits of some ultrabasic rock bodies in southeastern Alaska: U.S. Geol. Survey Bull. $947-D$, p. 65-84.

Twenhorel, N. S., Reed, J. C., and Gates, G. O., 1949, some mineral investigations in southeastern Alaska: U.S. Geol. Survey Bull. $963-A$, p. $1-45$.

Twenhorel, W. S., 1951, Geology of proposed Blue Lake dam site and tunnel near Sitka, Alaska: U.S. Geol. Survey C1rc. 147,4 p.

Cederstrom, D. J., 1952, Sumary of ground-water development in Alaska, 1950: U.S. Geol. Survey Circ. 169, 37 p.

Flint, G. M., Jr., and Cobb, E. H., 1953, Gypsum deposits near Iyoukeen Cove, ChIchagof Island, southeastern Alaska! U.S. Geol. Survey Bull. $989-8$, p. $27-37$.

Kumbel, Bernhard, 1953, American Triassic colled neutiloids: U.S. Geol. Survey Prof. Paper 250, 204 p.

Twenhofel, W. S., 1953, Potential Alaskan mineral resources for proposed electrochernical and electrometallurgical industries In the upper I,ynn Canal area, Alaska: U.S. Geol. Survey Circ. 252, 14 p: 
West, $\%$. S., and Benson, P. D., 1955, Investigations for radioactive deposits in southeastern Alaska! U.S. Geol. Survey Bull. 1024-B, p. 25-57.

lohr, E. W., 1957, Chemteal character of public water supplies of the larger cities in Alaska, Fawa11, and Puerto Rico, 1954: U.S. Ceol. Survey Water-Supply Paper 1460-A, p. 1-39.

Mlller, D. J., Payne, T. G., and Gryc, George, 1959, Geology of poosible petroleum provinces in Alaska, with an annotated bibliography by E. H. Cobb: U.S. Geol. Survey Bull. 1094, 131 p.

\section{SKAGWAY QUADRANGTE:}

Smlth, P. S., 1941, Fineness of gold from Alaska placers: U.S. Geol. Survey Bull. 910-C, p. 147-272.

Smith, P. s., 1942, Occurrences of molybdenum minerals in Alaska: U.S. Geol. Survey Bull. 926-C, p. 161-210.

Twenhofel, W. S., Roblnson, G. D., atd Gault, H. R., 1946, Molybdenite investigations in eoutheastern Alaska: U.S. Geol. Survey Bull. 947-8, p. $7-38$.

Cederstrom, D. J., 1952, Sumary of ground-water development in Ales'ka, 1950: U.S. Geol. Survey Circ. 169, 37 p.

Jchnson, s.rthur, and Twenhofel, W. S., 1953, potertial industrial sites in the Lynn Canal area, Alaska! U.S. Geol. Survey Cire. $280,17 \mathrm{p}$.

Thienhofel, $\because$. S., 1953, Potential Alaskan mineral resources for proposed electrochemical and.electrometallurgical industries in the upner Lynn Canal area, Alaska; U.S. Geol. Survey Circ: $252,24 \mathrm{p}$.

Carr, M. S., and Dutton, C. E., 1959, Iron-ore resources of the United States including Alaska and puerto Rico: U.S. Geol. Survey Bull. $1082-C$, p. $61-.234$.

\section{SLFTTMUTE QUADRANGLE}

Smth, P. S., 19li, Fineness of gold from Alaska ylacers: U.S. Geol. Survey Bull. 910-C, p. 147-272.

Smith, P. S., 1941, Past lode-gold production from Alaske! U.S. Geol. survey Bul1. 917-C, p. 159-212.

Smith, T. S., 19l.1, Mineral industry of Alaska in 1939: U.S. Geo2. Survey Bull. 926-A, p. 1-106.

Swith, P. S., 1942, Mineral industry of Alaske in 1940: U.S. Geo1. Survey Buzl. 933-A, p. 2-102.

Cady, W. M., Wallace, R. E., Hoare, J. M., and Vebber, E. J., 1955, The central Kuskokwim region, Alaska: U.S. Geol. Survey Frof. Paper 268, 132 p. 


\section{SOLOMON QUADRANGL}

Smtth, P. S., 1941, Fineness of gold from Alaska placers! U.S. Geol. Survey Buld. 910-C, p. 147-272.

Smt th, P. S., 194l, Past lode-gold production from Mlaska! U.S. Geol. Survey Bull. 917-C, p. 159-212.

Smith, P. S., 1941, Mineral industry of Alaska in 1939: U.S. Gool. Survey Bull. 926-A, p. 1-106.

Smith, P. S., 1942, Mineral industry of Alaska in 1940: U.S. Geol. Survey Bur1. 933-A, p. 1-102.

White, M. G., West, W. S., Tolbert, G. E., Nelson, A. E.:; end Houston, J. R., 1952, Preliminary summary of reconnaissance for uranium in Alaska, 1951: U.S. Geol. Survey Circ. 196, 37 p.

Bates, R. G., and Hecors, Helmuth, Jr., 1953, Preliminary summary revier of thorlum-bearing raineral occurrences in Alaska: U.S. Geol. Survey Circ. 202, $13 \mathrm{p}$.

Péwé, T. L., and others, 1953, Mutiple glaciation in Alaska, a progress report: U.S. Geol. Survey Circ. $289,13 \mathrm{p}$.

Weat, H. S.. 1953, Recomnaissance for radionctive deposits in the Darby Mountains, Seward Peninsula, Alaska, 1948: U.S. Geol. Survey Cire. 300, 7 p.

Thite, M. G., Nest, B. S., and Matzko, J. J., 1953, Reconnaissance for redioactive deoosits in the vicinity of Teller and Cape None, Sevard Peninsule, Alaska, 1946-117: U.S. Geol. Survey Circ. 244, $8 \mathrm{p}$.

Miller, D. J., Payne, T. G., and Grye, George, 1959, Geology of possible petroleum provinces in Alaska, with an annotated bibliography by E. H. Cobb: U.S. Geol. Survey Bull. 1094, 13I p.

\section{STYPOVAK BAY QUADRANGLE}

Mliler, D. J., Payme, T. G., and Gryc, George, 1959, Geology of posstble petroleur provinces in Alaska, with an annotated bibliography by E. K. Cobb: U.S. Geol. Survey Bull. 1094, 131 p. 
Smsth, P. S., 1941, Past lode-gold production from Alaska: U.S. Geol. Survey Bull. 917-C, p. 159-212.

Smith, P. S., 1942, Mineral industry of Alaska in 1940: U.S. Geol. Survey Bul1. 933-A, p. 1-102.

Gault, H. R., and Fellows, R. E., 1953, Zinc-copper depostt at Tracy. Arm, Petersburg district, Alakka: U.S. Geol. Survey Bull. 998-A, p. $1-13$.

Twerhofel, W. S., 1953, Potential Alaskan mineral resources for proposed electrochemical and electrometaliurgical industries in the upper Lynn Canal area, Alaska: U.S. Geol. Survey Circ. 252, $14 \mathrm{p}$.

Wedow, Helmuth, Jr., and others, 1953, Preliminary sumary of reconnaissance for uranium and thorlum in Alaska, 1952! U.S. Geol. Survey Circ. $248,15 \mathrm{p}$.

Houston, J. R., Bates, R. G., Vellkanje, R. S., and Wedow, Helmuth, Ir., 1958, Reconnaissance for radioactive deposits in southeastern Alaska, 1952: U.S. Geol. Survey Bull. 1058-A, p. 1-31.

Carr, M. S., and Dutton, C. E., 1959, Iron-ore resources of the United States including Alaska and Puerto RIco: U.S. Geol. Survey Bull. $1082-c$, p. $61-134$.

\section{SURVEY PASS QUADRANGLE}

Smith, P. S., 19hI, Mineral industry of Alaska in 1939! U.S. Geol. Survey Bull. 926-A, p. 1-106.

\section{TAKU RIVER QUADRANGLE}

Smith, P.S., 1941, past lode-gold production from Alaska! U.S. Geol. Survey Buli. 917-C, p. 159-212.

Wedow, Helmuth, Jr, and others, 1953, Preliminary summary of reconnalssance for urantum and thorium in Alaska, 1952: U.S. Geol. Survey Cire. 248, $15 \mathrm{p}$.

Houston, J. R., Bates, R. G., velikanfe, R. S., and Wedow, helmuth, $\mathrm{Jr} ., 1958$, Reconnalssance for radoactive deposits in southeastern Alaska, 1952: U.S. Geol. Survey Bull. 1058-A, p. 1-31.

Jaffe, H. W., Gottfried, David, Waring, C. L., and Worthing, E. W., 1959, Lead-alphe age deteminations of accessory minerals of igneous rocks (1953-1957): U.S. Geol. Survey Bull. 1097-8, p. 65-148. 
Capps, S. R., 1940, Geology of the Alaska Railroed region! U.S. Geol. Survey Bull. 907, 201 p.

Smith, P. Si, 1941, Hineness of gold from Alaske placers: U.S. Geol. Survey Bull. 910-C, p. 147-272.

Smith, P. S., 1941, Mineral industry of Alaska in 1939: U.S. Geol. Survey bull. 926-A, p. 1-106.

Smith, P. S., 19li2, Occurrences of molyboenum minerals in Alaska: U.S. Geol. Survey Bull. 926-C, p. 161-210.

Srith, P. S., 1942, Mineral industry of Alaska in 19!0: U.S. Geol. Survey Bu11. 933-A, p. 1-102.

Waring, G. A., 1947, Nonmetalliferous deposits in the Nlaska Radlroad belt: U.S. Geol. Survey Circ. 18, 10 p.

Cederstrom, D. J., 1952, Summery of groundwater development in Alaska, 1950: U.S. Geol. Survey Circ. 169, 37 p.

Rates, R. G., and Wedow, Helmuth, Jr., 1953, Preliminary summary review of thortum-bearlng mineral occurrences in Mlaska: U.S. Geol. Survey Circ. 202, $13 \mathrm{p}$.

Robinson, G. D., Hedow, Helmuth, Jr., and Lyons, J. B., 1955, Radioactivity investigations in the Cache Creek area, Yentro ilstrict, Alaska, 1945: U.S. Geol. Survey Bull. 1024-A, p. 1-23.

Miller, D. J., Payme, T. G., and Gryc, George, 1959, Geology of posstble petroleum provinces in Alaska, with an annotated bibliography by ¿. H. Cobb: U.S. Geol. Survey Bull. 1094, 131 p.

TALKETTHA MOLNMINS QUADRAIGLE

Capps, S. R., 1940, Geoloby of the Alaska Raliroed region: U.S. Geol. Survey Bull. $907,201 \mathrm{p}$.

Smith, P. S., 1941, Fineness of gold Prom Alaska placers! U.S. Geol. Survey Bull. 910-C, p. 147-272.

Smith, P. S., 19lk1, Mtheral industry of Alaska in 1939: U.S. Geol. Survey Bull. 926-A, p. 1-106.

Smith, P. S., 19lip, Occurrences of molybdenum minerals in Alaka:

U.S. Geol. Survey Bull. 926-C, p. 161-210.

Smith, P. S., 1942, Mineral industry of Alaska in 1940: U.S. Geol. Survey Burl. 933-A, p. 1-102. 
Noxham, R. M., and Nelson, A. E., 1952, Reconnaissance for radio. active deposits in south central Alaska, 19l.7-49: U.S. Geol. Survey circ. $184,14 \mathrm{p}$.

White, M. G., West, W. S., Tolbert, G. E., Nelson, A. E., and Houston, J. R., 1952, Preliminary summary of reconnaissance for uranium in Alaska, 1951: U.S. Geol. Survey Circ. 196, 17 p.

Imlay, R. W., 1953, Callovian (Jurasste) ammonites from the united States and Alaska, Part 2, Alaska Fenzinsula and Cook Inlet regions: U.S. Geol. Survey Prof. Paper 249-B, p. 41-108.

Miller, D. J., Payne, T. G., and Gryc, Geore, 1959, Geology of possible petroleum provinces in Alaska, with en annotated bibliography by F. H. Cobb: U.S. Geol. Survey Bull. 1094, 131 p.

\section{TANACROSS QUADRANGLE}

Smith, P. S., 1942, Mineral industry of Alaska in 1940: U.S. Geol. Survey Bull. 933-A, p. 1-102.

Moffit, F. H., 1944, Mining in the northern Copper River region, Alaske: U.S. Geol. Survey Bull. 943-B, p. 25-47.

Cederstrom, D. J., 1952, summary of ground-water development in Alaska, 1950: U.S. Geol. Survey Circ. 169, $37 \mathrm{p}$.

Bates, R. G., and Wedow, Helmuth, Jr., 1953, Preliminary sumary review of thorium-bearing mineral occurrences in Alaska: U.S. Geol. Survey Cire. 202, 13 p.

Noffit, F. K., 1954, Geology of the eastem part of the Aleske Range and adjacent area: U.S. Geol. Survey Bull. 989-D, p. 63-218.

Wedow, Helmuth, Jr., Kllleen, P. L., and others; 1954, Reconnaissance for radioactive deposits in eastern interior Alaska, 1946: U.S. Geol. Survey Circ. 331, 36 p.

Larsen, E. S., Jr., Gottfried, David, Jaffe, H. W., and Waring, C. L., 1958, Lead-alpha ages of the Mesozoic batholiths of westem North America: U.S. Geol. Survey Bull. 1070-8, p. 1-33.

Gottfried, David, Jeffe, H. H., end Senftle, F. E., 1959, Evaluation of the lead-alpha age determinations of accessory minerals of igneous rocks: U.S. Geol. Survey Bull. 1097-A, p. .2-63.

Jaffe, H. W., cottried, Devid, Waring, C. L., and Worthing, H. W., 1959, Lead-alpha age determinations of accessory minerals of igneous rocks (1953-1957): U.S. Geol. Survey Bull. 1097-B, p. 65-148. 
Capps, S. R., 1940, Geology of the Alaska Railroad reglon: U.S. Geol. Survey Bu23. 907, 201 p.

Smith, P. S., 1941, Fineness of gold from Mlaske placers: U.S. Geol. survey Bull. 910-C, p. 147-272.

Smith, P. S., 1941, past lode-gold production from Alaska! U.S. Geol. Survey Bull. 917-C, p. 159-212.

Smith, P. S., 1941, Mineral inaustry of Mlaska in 1939: U.S. Geol. Survey Bull. 926-A, p. 1-106.

Smith, P. S., 1942, Mineral industry of Alaska in 1940: U.S. Geol. Survey Bull. 933-A, p. 1-102.

Cederstrom, D. J., 1952, Summary of ground-water development in Alaska, 1950: U.S. Geol. Survey Circ. 169, 37 p.

Bates, R. G., and Wedow, Helmuth, Jr., 1953, Preliminary summary review of thorium-bearing mineral occurrences in Alaska: U.S. Geol. Survey Circ. 202, 13 p.

Moxham, R. M., 1954, Reconnaissance for radioactive deposits in the Manley Hot Springs-Rampart district, east-central Alaska, 1948: U.S. Geol. Survey Cire. 317, $6 \mathrm{p}$.

Wedow, Helmuth, Jr., Killeen, P. L., and othex's, 1954, Reconnaissance for radioactive deposits in eastern interior Alaska, 1946: U.S. Geol. Surrey Circ. $331,36 \mathrm{p}$.

Cariy, W. M., Wallace, R. E., Hoare, J. M., and Webber, E. J., 1955, The central Kuskokwin region, Alaska: U.S. Geol. Survey Prof". Paper 268, $132 \mathrm{p}$.

Miller, D. J., Payne, T. G., and Gryc, George, 1959, Geology of possible petroleum provinces in Alaska, with an annotated bibllography by E. H. Cobb: U.S. Geol. Survey Bull. 1094, 131 p.

\section{TAYTOR MOUNTAINS QUADRATGG,F}

Cady, W. M., Wallace, R. E., Hoare, J. M., and Webber, E. J., 1955, The central Kuskokwim region, Alaska: U.S. Geol. Survey Frof. paper 268, $132 \mathrm{p}$. 
Smith, P. S., 1941, Fineness of gold from Mlaska placers: U.S. Geol. Survey Bull. 910-C, p. 147-272.

Smith, P. S., 1941, Mineral industry of Mlaska in 1939: U.S. Geol. Survey Bull. 926-A, p. 1-106.

Smith, P. S., 1942, Occurrences of molybdenum minerais in Alaska: U.5. Geol. Survey Bull. 926-C, p. 161-210.

Smith, P. S., 1942, Mineral industry of Alasha in 1940! U.S. Geol. Survey Bull. 933-A, p. 1-102.

Cederstrom, D. J., 1952, sumnary of ground-water development in Alaska, 2950: U.S. Geol. Survey Circ. 169, 37 p.

West, W. S., and wite, M. G., 1952, the occurrence of zeunerite at Brooks Mountain, Seward Peninsula, Alaske: U.S. Geol. Survey C1rc. $214,7 \mathrm{p}$.

White, M. G., West, W. S., Tolbert, G. E., Nelson, A. E., and Houston, J. R., 1952, Preliminary sumnary of reconnaissance for uranium in Alagke, 1951: U.S. Geol. Survey Circ. 196, 17 p.

Bates, R. G., and Wedow, Helmuth, Jr., 1953, Preliminary summary review of thorium-bearing mineral occurrences in Aleska: U.S. Geol. Survey Circ. 202, $13 \mathrm{p}$.

Moxham, R. M., and West, W. S., 1953, Radiaactivity investigations in the Serpentine-Kougarok area, Seward Peninsula, Alaska, 1946: U.S. Geol. Survey Circ. 265, il p.

Péwé, T. L., and others, 1953, Multiple glaciation in Alaska, a progress report: U.S. Geol. Survey Circ. 289, 13 p.

Twenhofel, W. S., 1953, Potential Alaskan mineral resources for proposed electrochemical and electrometallurgical industries In the upper Lynn Canal area, Alaska: U.S. Geol. Survey Circ. 252, 14 p.

Wedow, Helmuth, Jr., and others, 1953, Preliminary summary of reconnalsaance for uranium and thorium in Alaska, 1952: U.S. Geol. Survey Circ. $248,15 \mathrm{p}$.

White, M. G., and West, W. S., 1953, Reconraissance for uranium in the Iost River area, Seward Peninsula, Alaska, 1951! U.S. Geol. Survey circ. $319,4 \mathrm{p}$.

White, M. G., West, W. S., and Matzko, J. J., 1953, Reconnaissance for radloactive deposits in the vicinity of Teller and Cape Nome, Seward Peninsula, Alaska, 1946-47: 13.S. Geol. Survey Circ. 244, 8 p. 
Hopkins, D. M., Karlstrom, M. N. V., and others, 1955, Permafrost and ground waler in Alaska: U.S. Geol. Survey Prof. Paper 264-F, p. $113-145$.

Killeen, P. L., and Ordway, R. J., 1955, Radioactivity investigations at Ear Mountain; Sewand Peninsula, Alaska, 1945: U.S. Geol. Survey Bull. 1024-C, p. 59-9h.

\section{TESHERPUK QUADRANGLE}

Tappan, Helen, 1951, Foraminifera from the Arctic slope of Alaska, General introduction and Part I, Triassic Foraminifera: U.S. Geol. Survey Prof. Paper 236-A, p. 1-20.

Imiay, R. W., 1955, Characteristic Jurassic mollusks from northern Alaska: U.S. Geol. Survey Prof. Faper 274-D, p. 69-96.

Tappan, Helen, 1955, Foraminlfere from the Arctic slope of Alaska, Part 2, Jurassic Foraninifera: U.S. Geol. Survey Prof. Paper $236-B$, p. 2l-90.

MacNeil, F. S., 1957, Cenozoic megafossils of northern Alaska: U.S. Geol. Survey Prof. Paper 294-C, p. 99-126.

Colltns, F. R., 1958, Test wells, Topagoruk area, Alaska, with Micropaleontologic study of the Topagoruk test wells, northern Alaska, by H. R. Bergquist: U.S. Geol. Survey Prof. Paper 305-D, p. $205-316$.

Reed, J. C., 1958, Exploration of Neval Petroleur Reserve No. 4 and adjacent areas, northern Alaska, 1944-53, part 1, History of the exploration: U.S. Gcol. Survey Prof. Paper 301, 192 p.

Miller, D. J., Payme, T. G., and Grye, George, 1959, Geology of possible petroleum provinces in Alaska, with an ennotated bibliography by

E. H. Cobb: U.S. Geol. Survey Bul1. 1094, 133 p.

Robinson, F. M., 1959, Test wells, Simpson area, Alaska, with a section on Core analyses by S.T. Yuster: U.S. Geol. Survey Prof. Paper 305-J, p. 523-568.

\section{MRTNTTY ISLANDS QUADRANGLE}

Smith, P. S., 1941, Fineness of gold from Alaska placers: U.S. Geol. Survey Bull. 910-C, p. 147-272. 
Capps, S. R., 1940, Geology of the Alaske Pailroad reglon: U.S. Geol. Survey Bull. $907,201 \mathrm{p}$.

Coats, R. R., 1950, Volcanic activity in the Aleutian arc: U.S. Geol. Survey Bull. 974-B, p. 35-49.

Bates, R. G., and Wedow, Helmuth, Jr., 1953, Preliminaxy summary review of thorium-bearing mineral occlirrences in Alaska: U.S. Geol. Survey Circ. 202, 13 p.

Pewé, r. L., and others, 1953, Mittule gleciation in Alaska, a progress report: U.S. Geol. Survey Circ. 289, 13 p.

Miller, D. J., Payne, T. G., and Gryc, Georste, 1959, Goology of posstble petroleum provinces in Alaska, with an annotated bibliography by E. H. Cobb! U.S. Geol. Surviযy Bull. 1094,131 p.

Milier, R. D., and Dobrovolny, Ernest, 1959, surficial geoloes of Anchorage and vicinity, Alaska: U.S. Geol. Survey Bull. 1093, $128 \mathrm{p}$.

Wilcox, R. E., 1959, some effects of recent volcanic ash fails, with special reference to Alaska: U.S. Geol. Survey Bull. 1028-N, p. $409-476$.

\section{ITGASHJK QUADRANGLE}

Coats, R. R., 1950, Volcanic activity in the Aleutian arc: U.S. Geol. Survey Bull. 974-B, p. 35-49.

Imlay, R. W., 1953, Callovian (Jurassic) ammonites from the United States and Alaska, Part 2, Alaska Peninsula and Cook Inlet reglons: U.S. Geol. Survey prof. Paper 249-B, p. 41-108.

Miller, D. J., Payne, T. G., and Gryc, George, 1959, Geology of possible petroleum provinces in Alaska, with an annotated bibliography by E. H. Cobb: U.S. Ceol. Survey Bull. 1094, 131 p.

\section{UMCAT QUADRANGLE}

Péwe, T. L., and others, 1953, Multiple glaclation in Alasika, a progress report: U.S. Geol. Survey Circ. 289, $13 \mathrm{p}$.

MacNeil, F. S., 1957, Cenozoic megafossils of northern Alaska:

U.S. Geol. Survey Prof. Paper 294-C, p. 99-126. 
Collins, F. R., 1958, Test wells, Umiat area, Alaska, with Micropaleontologic study of the umiat field, northern hlaska, by H. R. Bergquist, and sections on Temperature measurement studies, by M. C. Brewer, and Core analyses, Umiat test welz 9, by G. L. Gates: U.S. Geol. Survey Prof. Paper 305-B, p. 71-206.

Reed, J. C., 1958, Exploration of Naval Petroleum Reserve No. 4 and adjacent areas, northern Alaska, 1944-53, part 1, History of the exploration: U.S. Geol. Survey Prof. Paper 301,192 p.

Robinson, F. M., 1958, Test wells, Gubik area, Alaska, with Microm paleontologic study of the Gubik test wells, northern Alaska, by H. R. Bergquist: U.S. Geol. Survey Prof. Paper 305-C, p. 207264.

Lachenbruch, A. H., 1959, Periodic heat flow in a stratified medium with application to permafrost problems: U. Geol. Survey Bull. 1083-A, p. $1-36$.

Miller, D. I., Payne, T. G., and Gryc, George, 1959, Geology of possible petroleum provinces in Alaska, with an annotated bibliography by E. H. Cobb: U.S. Geol. Survey Bull. 1094, 131 p.

Roblnsor, F. M., and Collins, F. R., 1959, core test, sentinel Hill irea and test well, Fish Creek area, Alaska: U.S. Geol. Survey Prof. Paper 305-I, p. 485-521.

\section{UMNAK QUADRANGLE}

coats, R. R., 1950, Volcaric activity in the Aleutian are: U.S. Geol. survey Bull. 974-B, p. 35-49.

Byers, F. M., Jr., 1959, Geology of Ummak and Bogoslof Islands, Alaska: U.S. Geol. Survey Bull. 1028-L, p. 267-369.

Wicox, R. E., 1959, some effects of recent volcanic ash falls, with special reference to Alaska: U.S. Geol. Survey Buli. I028-N, p. $409-476$.

\section{UNATAKTEETI QUADRANGLE}

Smith, P. S., 1942, Occurrences of molybdenum minerals in Alaska: U.S. Geol. Survey Bull. 926-C, p. 161-210.

Cederstrom, D. J., 1952, Sumary of ground-water development in Alaska, 1950! U.S. Geol. Survey Circ. 169. 37 D.

Wedow, Helmuth, Jr., and others, 1953, Preliminary sumary of reconnaissance for uranium and thoriur in Alaska, 1952: U.S. Geol. Survey Circ. 248, 15 p.

West, W. S., 1954, Reconnaissance for radioactive deposits in the lower Yukon-Kuskokw1m region, Alaska, 1952: U.S. Geol. Survey circ. $328,10 \mathrm{p}$.

Miller, D. J., Payne, T. G., and Gryc, George, 1959, Geology of poscible petroleum provinces in Alaska, with an annotated bibliography by E. H. Cobb: U.S. Geol. Survey Bull. 1094, 131 p. 
Coats, R. R., 1950, Volcanic activity in the Aleutian are: U.S. Geol. Survey Bull. 974-B, p. 35-49.

Twerhofe1, W. S., 1953, Potential Alaskan inl neral resources for proposed electrochemical and electrometallurgical industries in the upper Lynn Canal area, Alaska: U.S. Geol. Survey ctrc. 252, 14 p:

Byers, F. M., Jr., 1959, Gelogy of Unmak and Boğoslof Islands, Alaska! U.S. Geol. Survey Bull. 1028-L, p. 267-369.

\section{UNIMAK QUADRANGLE}

Coats, R. R., 1950, Volcanic activity in the Aleutian arc: U.S. Geol. Survey Bull. 974-E, p. 35-49.

\section{UTUKOK RTVER QUADRANGLE}

Collins, F. R., 1958, Test wells, Meade and Keolak areas, Alaska, with Micropaleontology of Meade test well 1 and Kaolak test well I, northern Alaska, by H. R. Bergquist: U.S. Geol. Survey Prof. Paper 305-F, p. 3lil-376.

Reed, J. C., 1958, Exploration of Naval Petroleum Reserve No. 4 and adjacent areas, northern Alaska, 1944-53, part 1, History of the exploration: U.S. Geol. Survey Prof. Paper 30l, $192 \mathrm{p}$.

Miller, D. J., Payme, T. G., and Gryc, George, 1959, Geology of possible petroleum provinces in Alaska, with an annotated bibliography by E. H. Cobb: U.S. Geol. Survey Bull. 1094, 131 p.

\section{VATDEZ QUADRANGIE:}

Smith, P. S., 1941, Past lode-gold production from Alaska: U.S. Geol. Survey Bull. 917-c, p. 159-212.

Smith, P. S., 1941, Mineral inaistry of Alaska iv 1939: U.S. Geol. Survey Butl. 926-A, p. 1-106.

Silth, P. S., 1942, Occurrences of molybdenum merals in Alaska! U.S. Geol. Survey Bull. 926-C, p. 261-210.

Smith, P. S., 1942, Mineral industry of Alaska in 1940: U.S. Geol. Survey Bull. 933-A, p. 1-102.

Kingston, Jack, and Miller, D. J., 1945, Nickel-copper prospect near Spirit Mountain, Copper River region, Alaska: U.S. Geol. Survey Bul1. 943-C, p. 49-57.

Van Alstine, R. F', and Black, R. Fi, 1946, copper deposits of the Kotsina-Kuskulana a1strict, Alaska: U.S. Geol. Survey Bull. 947-G, .p. 121-141. 
Moffit, F. H., and Fellows, R. E., 1.950, Copper deposits of the Prince William Sound district, Alaska: U.S. Geol. Survey buzl. 963-B, p. 47-80.

Cederstrom, D. J., 1952, Summary of ground-water development in Aleska, 1950: U.S. Geol. Survey Cire. 169, 37 p.

Moxhar, R. M., and Nelson, A. E., 1952, Reconnaissance for radiow active deposits in south-central Alaske, 1947-49: U.S. Geol. Survey Cire. 184, $14 \mathrm{p}$.

Twenhofel, W. S., 1953, potential Alasken mineral resources for proposed electrochemical and electrometallurgical industries in the upper Lynn Canal area, Alaska! U.S. Geol. Survey circ. 252,14 p.

Wedow, Helmuth, Jr., and others, 1953, Preliminary summary of reconnalssance for uranium and thorium in Alaska, 1952: U.S. Geol. Survey Circ. 2!8, $15 \mathrm{p}$.

Moffit, F. H., 1954, Geology of the Prince William sound reglon, Alaska: U.S. Geol. Survey Bull. 989-E, p. 225-310.

Miller, D. J., Payne, T. G., and Gryc, George, 1959, Geology of poarlble petroleum provinces in Alaska, with an annotated bibliography by F. H. Cobb: U.S. Ceol. Survey Bull. 1094, 131 p.

\section{WAINWFIGHT QUADRANCLE}

Smith, P. S., 1941, Myeral industry of Alaska 1n 1939: U.S. Geol. Survey Bull. 926-A, p. 1-106.

Sirith, P. S., 1942, Mineral industry of Alaske in 1940: U.S. Geol. Survey Buzl. 933-A, P. 1-10.

MacNeil, F. S., 1957, Cenozoic megafossils of northern Alaska:

U.S. Geol. Survey Prof. Papex 294-C, p. 99-126.

\section{WISEMAN OUADRANGLF}

Smith, P. S., 1941, Fineness of gold from Alaska placers: U.S. Geol. Survey Bull. 910-C, p. 147-272.

Sratth, P. S., 1941, Mineral industry of Alaska in 1939: U.S. Geol. Survey Bull. 926-A, p. 1-106.

Smlth, P. S., 1941, Past 10de-gold production from Alaska! U.S. Geol. Survey Bull. 917-C, p. 159-212.

Srith, P. S., 1942, Mineral industry of Alaska in 1940: U.S. Geol. Survey Buil: 933-A, p. 1-103. 
White, M. G., 1952, Radioactivity of selected rocks anu placer concentrates from northeastem Alaska: U.S. Geol. Survey Cire. 195, $12 \mathrm{p}$.

Bates, R. G., end Wedow, Helmuth, Jr., 1953, Preliminary summary review of thorium-bearing mineral occurrences in Alaska: U.S. Geol. Survey Circ. 202, 13 p.

Wedow, Helmuth, $J x$. , and others, 1953, Preliminary summary of reconnalssance for uranium and thorium in Alaska, 1952: U.S. Geol. Survey circ. $21.8,15 \mathrm{p}$.

Nelson, A. E.; West, W. S., and Matzko, J. 3., 1954, Reconnalssance for redioactive deposits in eastern Alaska, 1952! U.S. Geol. Survey circ. 348 , 21 p.

\section{YAKTTAT QUADRANGLE}

Cederstrom, D. J., 1952, Summary of ground-water development in Alaska, 1950: U.S. Geol. Survey Clre. 169, 37 p.

Miller, D. I., Payne, T. G., and Grye, Ceorge, 1959, Geologs of possible petroleum provinces in Alaska, with an annotated bibliography by E. H. Cobb: U.S. Geol. Survey Bull. 1094, 131 p. 